\title{
Astrocyte elevated gene-1 in relation to colorectal cancer development and radiotherapy response
}

\author{
Sebastian Gnosa
}

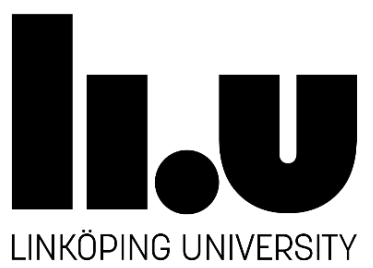

Division of Clinical Sciences

Department of Clinical and Experimental Medicine

Faculty of Medicine and Health Sciences

Linköping University, SE-581 85 Linköping, Sweden 
(C) 2015 Sebastian Gnosa

ISBN 978-91-7685-970-4

ISSN 0345-0082

All previously published articles have been reprinted with the permission of the publisher.

Figures were produced by the author using Servier Medical Art (www.servier.com).

Printed by Liu-Tryck, Linköping, Sweden 2015 
"Man bewegt nichts, wenn man sich selber nicht bewegt" Blumentopf 


\section{Supervisor}

Xiao-Feng Sun, Professor

Department of Clinical and Experimental Medicine

Linköping University, Linköping, Sweden

\section{Co-supervisor}

Hans Starkhammar, PhD

Regional Cancer Centre Southeast

University Hospital Linköping, Linköping, Sweden

Hong Zhang, Associate Professor

School of Medicine

Örebro University, Örebro, Sweden

John Carstensen, Professor

Department of Medical and Health Sciences

Linköping University, Linköping, Sweden

\section{Faculty opponent}

Klas Wiman, Professor

Department of Oncology-Pathology

Karolinska Institutet, Stockholm, Sweden

\section{Board committee}

\section{Chris Anderson, Professor}

Department of Clinical and Experimental Medicine

Linköping University, Linköping, Sweden

\section{Elisabeth Åvall Lundqvist, Professor}

Department of Clinical and Experimental Medicine

Linköping University, Linköping, Sweden

\section{Bo Stenerlöw, Professor}

Department of Immunology, Genetics and Pathology

Uppsala University, Uppsala, Sweden 


\section{Abstract}

The incidence and death rate for colorectal cancer (CRC) decreased during the last decades as a result of improved diagnosis and treatment. However, CRC is still the third most common cancer in the world, and is responsible for about 700000 deaths per year worldwide. Therefore, it is important to understand the mechanisms of the disease, and to find molecular markers in order to further improve prognosis, and to develop new treatment strategies. Astrocyte elevated gene-1 (AEG-1), encoded by the $M T D H$ gene, is upregulated in a variety of cancers. AEG-1 is involved in cell survival, proliferation, migration, invasion, metastasis, angiogenesis, and apoptosis.

The aim of this thesis was to investigate the role of AEG-1 in CRC development and the impact of AEG-1 on the response of radiation treatment. The AEG-1 expression, analysed in different CRC patient cohorts in paper I and III, was increased in the tumour tissue compared with the normal mucosa, and higher in the lymph node and liver metastases. Expression analyses in normal and cancer cell lines confirmed these results. In paper II, sequencing of the complete coding sequence of the $M T D H$ gene in 356 patients revealed 50 single nucleotide variants of which 29 were novel. Eight exonic variants were detected, including three frameshift variants which were probably pathogenic, and two missense variants located in functional protein regions. There was no correlation of the $M T D H$ variants or AEG-1 expression with the patient survival. In paper III, we also investigated the impact of AEG-1 on the response to radiation treatment. AEG-1 knockdown decreased the cellular survival upon radiation in several colon cancer cell lines. The AEG-1 expression was furthermore analysed in patients, which were randomised to either surgery alone or preoperative radiotherapy (RT), followed by surgery. The rectal cancer patients with high AEG-1 expression treated with RT had a significantly higher risk of developing distant recurrence and had a worse disease free survival, likely due to the metastasis promoting properties of AEG-1. In paper IV, the impact of AEG-1 knockdown and radiation on migration and invasion was analysed in colon cancer cell lines in vitro and in a novel zebrafish model in vivo. AEG-1 knockdown decreased migration and invasion, and radiation-enhanced migration and invasion in the cell lines tested.

In conclusion, our data suggest that AEG-1 is involved in CRC development, while MTDH gene variants probably not have a high clinical importance in CRC. Furthermore, AEG-1 is a promising radiosensitising target and a valuable prognostic marker in CRC. We further showed that AEG-1 knockdown inhibits migration and invasion, as well as radiation-enhanced cell migration and invasion. 


\section{Populärvetenskaplig sammanfattning}

Kolorektalcancer är en av de vanligast förekommande cancerformerna I världen. Incidensen och dödligheten i kolorektalcancer har under de senaste årtiondena minskat, mycket på grund av en förbättrad vård och tidigare diagnos. Trots detta är kolorektalcancer fortfarande den tredje vanligaste cancerformen i världen, med uppskattningsvis 700000 dödsfall per år världen över. Därför är det viktigt att förstå sjukdomens bakomliggande mekanismer, samt att hitta molekylmarkörer som kan användas för att förbättra prognosen och för att utveckla nya behandlingsstrategier. AEG-1 (Astrocyte elevated gene-1) som kodas av MTDH genen, är en så kallad onkogen vilken uppregleras vid cancer och som reglerar cellers överlevnad, utveckling, metastasering, angiogenes och svaret på behandling.

Syftet med denna avhandling var att undersöka AEG-1s roll i utvecklingen av kolorektalcancer, samt om AEG-1 påverkar svaret på strålningsbehandling. Analys av mRNA- och proteinuttryck i olika grupper av kolorektalcancerpatienter visade en ökning av AEG-1 i tumörvävnaden jämfört med normal mucosa, det högsta uttrycket hittades i metastaser. MTDH genen sekvenserades i 356 patientprover varpå 29 nya genvarianter hittades. Däremot fanns de ingen korrelation mellan dessa nya MTDH varianter, uttrycket av AEG-1 och överlevnad. Vi studerade därför om uttrycket av AEG-1 påverkade svaret på strålningsbehandling. Genom att slå ut AEG-1 uttrycket, s.k. "knockdown", minskade överlevnaden i celler som utsatts för strålning i flera olika cancercellinjer. Därefter undersöktes AEG-1 uttrycket i patienter som hade genomgått antingen enbart kirurgisk behandling eller strålning före det kirurgiska ingreppet. Patienter som behandlades med strålning och vars AEG-1 uttryck var högt, visade sig ha en förhöjd risk att utveckla återfall samt uppvisade en sämre överlevnad, troligtvis beroende på AEG-1s främjande effekt på metastaseringen. Slutligen analyserades effekten av att slå ut AEG-1 på migration och invasion i både kolorektalcancerceller in vitro och $\mathrm{i}$ zebrafiskar in vivo. Att slå ut uttrycket av AEG-1 minskade inte enbart migrationen och invasionen i cellinjer, utan även den strålningsinducerade migrationen och invasionen.

Sammanfattningsvis har vi funnit att uttrycket av AEG-1, på både mRNA- och proteinnivå, är involverat i utvecklingen av kolorektalcancer. De olika genvarianterna av MTDH verkar inte ha en klinisk relevans vid kolorektalcancer. AEG-1 proteinet kan däremot vara en lovande prognostisk markör i kolorektalcancer. Vi har också funnit att minskat uttryck av AEG-1 hämmar migrationen och invasionen vid kolorektalcancer, samt även hämmar den strålningsinducerade migrationen och invasionen. 


\section{List of publications}

I. Gnosa $\mathbf{S}^{*}$, Shen YM*, Wang CJ, Zhang H, Stratmann J, Arbmann G, Sun XF. Expression of AEG-1 mRNA and protein in colorectal cancer patients and colon cancer cell lines. J Transl Med. (2012) 10:109.

II. Gnosa S*, Ticha I*, Haapaniemi S, Sun XF. MTDH genetic variants in colorectal cancer patients. Manuscript, Re-submitted to Sci Rep. (2015).

III. Gnosa S, Zhang H, Brodin VP, Carstensen J, Adell G, Sun XF. AEG-1 expression is an independent prognostic factor in rectal cancer patients with preoperative radiotherapy: a study in a Swedish clinical trial. Br J Cancer. (2014) 111:166-173.

IV. Gnosa S, Capodanno A, Jensen LDE, Sun XF. AEG-1 knockdown in colon cancer cell lines inhibits radiation-enhanced migration and invasion in vitro and in a novel in vivo zebrafish model. Manuscript (2015).

* Shared first authorship 


\section{List of publications outside the thesis}

Stratmann J, Wang CJ, Gnosa S, Wallin A, Hinselwood D, Sun XF, Zhang H. Dicer and miRNA in relation to clinicophatological variables in colorectal cancer patients. BMC Cancer (2011) 11:345.

Ticha I, Gnosa S, Lindblom A, Liu T, Sun XF. Variants of the PPARD gene and their clinicopathological significance in colorectal cancer. PLoS One (2013) 8;e83952.

Pathak S, Meng, WJ, Zhang H, Gnosa S, Nandy SK, Adell G, Holmlund B, Sun XF.

Tafazzin protein expression is associated with tumorigenesis and radiation response in rectal cancer: A study of Swedish trail on preoperative radiotherapy. PLoS One (2014) 9:e98317. 


\section{Table of Contents}

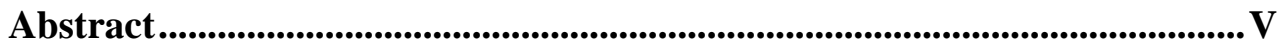

Populärvetenskaplig sammanfattning ........................................................ VII

List of publications........................................................................................

List of publications outside the thesis .......................................................................... X

List of abbreviations ..........................................................................................

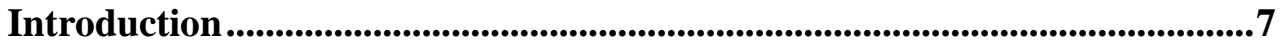

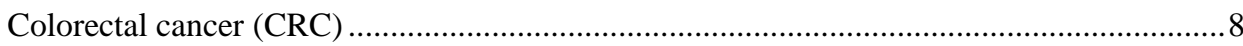

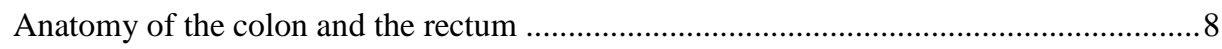

Risk factors for CRC - sporadic, familial, and hereditary ........................................... 10

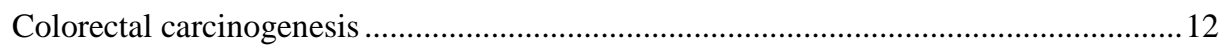

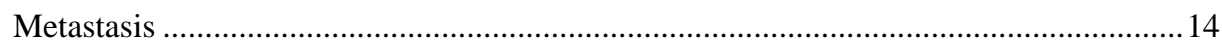

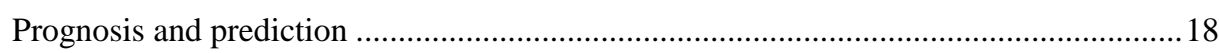

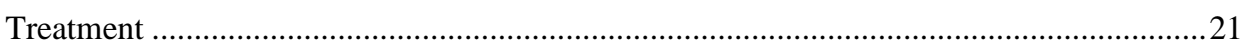

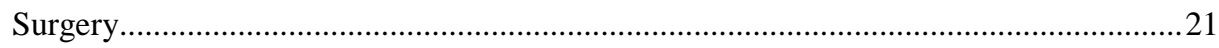

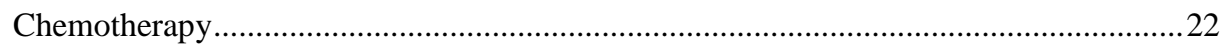

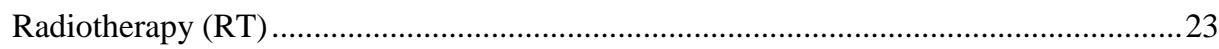

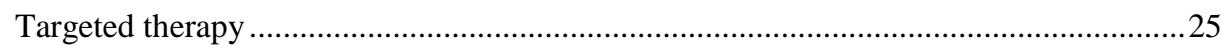

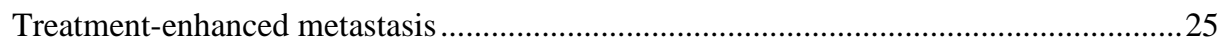

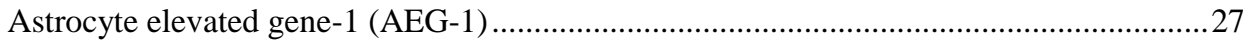

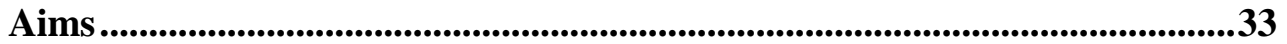

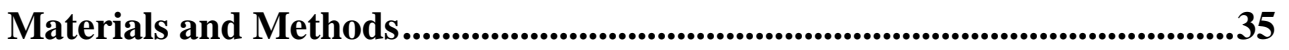

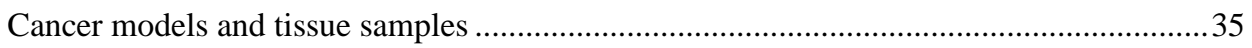

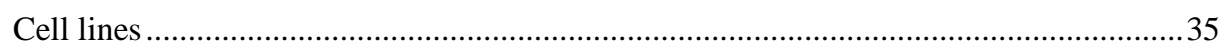

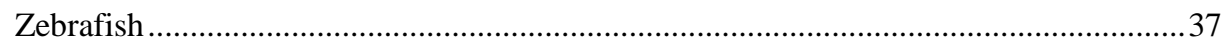

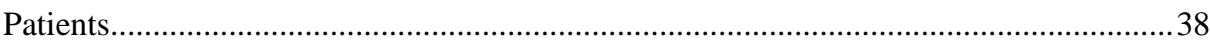

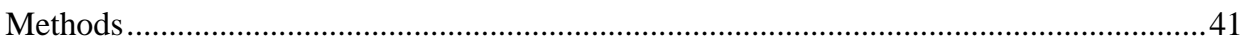

Irradiation of cell lines and zebrafish embryos .......................................................... 41

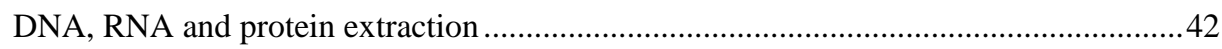

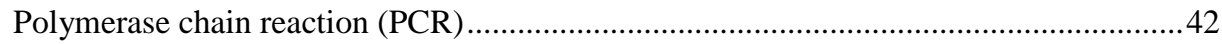

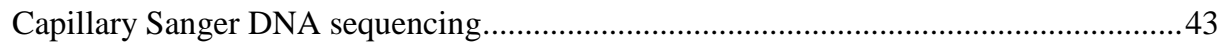

Quantitative PCR (qPCR) and Reverse transcription PCR ..........................................4

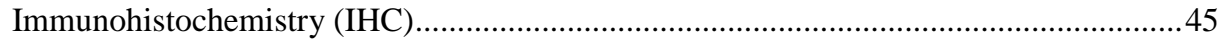




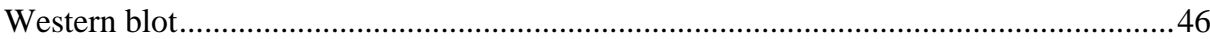

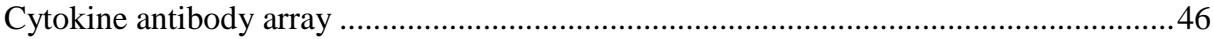

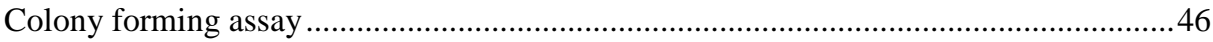

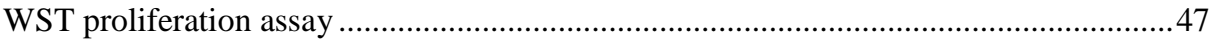

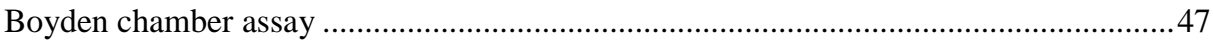

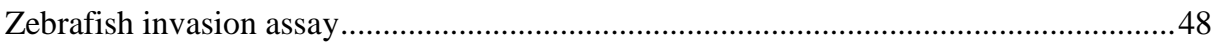

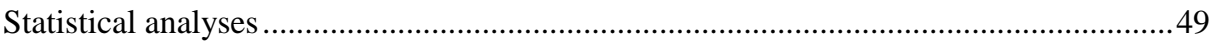

Results and Discussion..................................................................................

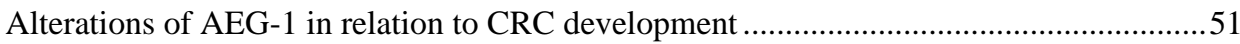

AEG-1 mRNA and protein expression in CRC patients and colon cancer cell lines .......51

MTDH genetic variants in CRC patients and colon cancer cell lines..............................53

AEG-1 alterations in relation to clinicopathological and biological variables.................55

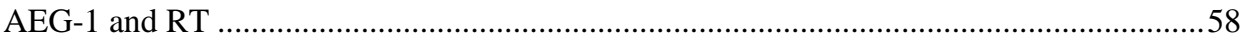

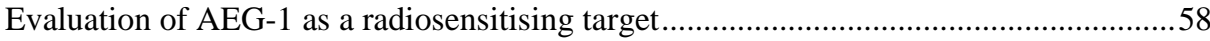

Potential of AEG-1 as a prognostic marker after RT ....................................................58

Impact of AEG-1 in radiation-enhanced metastasis .....................................................59

The zebrafish as a novel model to study radiation-enhanced invasion ............................61

MMP secretion and expression in relation to the AEG-1 expression and radiation.........61

Conclusions ..................................................................................................63

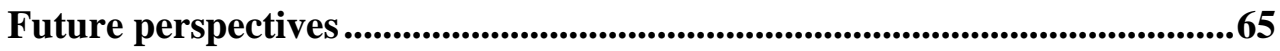

Acknowledgements.............................................................................67

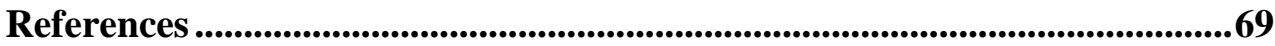




\section{List of abbreviations}

5-FU

ABCC11

AEG-1

AJCC

AKR1C2

ALDH3A1

Angptl 2

Angptl 4

APC

ATM

$\mathrm{Bad}$

$\mathrm{BCCIP} \alpha$

BCL-2

BCL-xl

BRAF

CAM

CBP

CCD

CD8

CDK2

cDNA

c-Myc

COSMIC

CPEB 1

CRC

CREB

CSC

CYP2B6

dbSNP

DCC

ddNTP

DIL

dNTPs

DPYD

DSB

ECM

EGF

EGFP

EGFR

EMEM

EMT

ERK

FAP

FFPE

FGFR

FOXO

FXYD-3 5-fluorouracil

ATP-binding cassette sub-family $\mathrm{C}$ member-11

Astrocyte elevated gene-1

American Joint Committee on Cancer

Aldo-keto reductase family 1 member-C2

Aldehyde dehydrogenase 3 family member-A1

Angiopoietin-like-2

Angiopoietin-like-4

Adenomas polyposis coli

Ataxia-telangiectasia-mutated

BCL2-associated agonist of cell death

BRCA2 and CDKN1A interacting protein alpha

B-cell CLL/lymphoma-2

B-cell lymphoma-extra large

B-Raf proto-oncogene

Cell adherence molecules

CREP binding protein

Charged coupled device

Cluster of differentiation- 8

Cyclin-dependent kinase-2

Complementary DNA

Cellular myelocytomatosis oncogene

Catalogue of Somatic Mutations in Cancer

Cytoplasmic polyadenylation element binding protein-1

Colorectal cancer

cAMP response element-binding protein

Cancer stem cells

Cytochrome P450 family 2 subfamily B polypeptide- 6

Single Nucleotide Polymorphism Database

Deleted in colorectal carcinoma

Dideoxynucleotide triphosphates

1,1' -dioctadecyl-3,3,3'3' -tetramethylindocarbocyanine

Deoxynucleotide triphosphates

Dihydropyrimidine dehydrogenase

Double strand breaks

Extracellular matrix

Endothelial growth factor

Enhanced GFP

Endothelial growth factor receptor

Eagle's Minimum Essential Medium

Epithelial to mesenchymal transition

Extracellular regulated MAP kinase

Familial adenomatous polyposis

Formalin fixed and paraffin-embedded

Fibroblast growth factor receptor

Forkheadbox

FXYD domain containing ion transport regulator-3 


\begin{tabular}{|c|c|}
\hline G-CSFR & Granulocyte colony-stimulating factor receptor \\
\hline GFP & Green fluorescence protein \\
\hline Gy & Gray \\
\hline Ha-Ras & Harvey rat sarcoma virus oncogene \\
\hline $\mathrm{HCC}$ & Hepatocellular carcinoma \\
\hline HGVS & Human Genome Variation Society \\
\hline HIV-1 & Human immunodeficiency virus-1 \\
\hline hMLH1 & MutL homolog-1 \\
\hline HMOX1 & Heme oxygenase- 1 \\
\hline hMSH2 & MutS homolog-2 \\
\hline HNPCC & Hereditary non-polyposis colon cancer \\
\hline HRP & Horseradish peroxidase \\
\hline HSP90 & Heat shock protein $90 \mathrm{kDa}$ \\
\hline ICAM-1 & Intercellular adhesion molecule-1 \\
\hline IGFR-1 & Insulin-like growth factor receptor-1 \\
\hline $\mathrm{IHC}$ & Immunohistochemistry \\
\hline IKK & I $\kappa \mathrm{B}$ kinases \\
\hline IL-1 & Interleukin-1 \\
\hline IL-8 & Interleukin-8 \\
\hline JAK1 & Janus kinase-1 \\
\hline K-Ras & Kirsten sarcoma viral oncogene homolog \\
\hline Lef & Lymphoid enhancer-binding factor \\
\hline Lox & Lysyl oxidase \\
\hline LYRIC & Lysine-rich CEACAM1 co-isolated \\
\hline MAPK & Mitogen-activated protein kinase \\
\hline MDM2 & MDM2 proto-oncogene \\
\hline Met & Met proto-oncogene \\
\hline MMP & Matrix metalloproteinase \\
\hline MMR & Mismatch repair \\
\hline MSI & Microsatellite instability \\
\hline mTOR & Mechanistic target of rapamycin \\
\hline NEMO & $\mathrm{NF}-\kappa \mathrm{B}$ essential modulator \\
\hline $\mathrm{NF}-\kappa \mathrm{B}$ & Nuclear factor- $\kappa B$ \\
\hline NLS & Nuclear localization signal \\
\hline NOS & Nitric oxide synthase \\
\hline N-Ras & Neuroblastoma RAS viral oncogene homolog \\
\hline NSCLC & Non-small cell lung cancer \\
\hline PCR & Polymerase chain reaction \\
\hline PDK & 3-phosphoinositide-dependent protein kinase \\
\hline PE & Plating efficiency \\
\hline $\mathrm{PI} 3 \mathrm{~K}$ & Phosphatidylinositol-4,5-bisphosphate 3-kinase \\
\hline PIP2 & Phosphatidylinositol-4,5-biphosphate \\
\hline PIP3 & Phosphatidylinositol-3,4,5-triphosphate \\
\hline PLZF & Promyelocytic leukaemia zinc finger \\
\hline PTEN & Phosphatase and tensin homolog \\
\hline PTU & 1-phenyl-2-thiourea \\
\hline qPCR & Quantitative PCR \\
\hline RhoA & Ras homolog family member A \\
\hline RISC & RNA induced silencing complex \\
\hline RNAi & RNA interference \\
\hline
\end{tabular}


ROCK

Rrs1

RT

SDS-PAGE

SF

shRNA

siRNA

SMAD2

SMAD4

SND1

STAT3

TCF

TGF- $\beta$

TIMP

TME

TNF- $\alpha$

Top1

TUNEL

UBN-1

VEGF

YY1

$\beta$-catenin
Rho-associated kinase

Ribosome biogenesis regulator homolog

Radiotherapy

Sodium dodecyl sulphate-polyacrylamide gel electrophoresis

Surviving fraction

Small (or short) hairpin RNA

Small inhibitory RNA

Smad family member-2

Smad family member-4

Staphylococcal nuclease and tudor domain containing-1

Signal transducer and activator of transcription-3

Transcription factor

Tumour growth factor beta

Tissue inhibitors of metalloproteinases

Total mesorectal excision

Tumour necrosis factor alpha

DNA topoisomerase I

Terminal deoxynucleotidyl transferase dUTP nick end labelling

Ubinuclein-1

Vascular endothelial growth factor

Yin-yang-1

Cadherin-associated protein beta 


\section{Introduction}

The oldest written records mentioning human cancer are two old Egyptian papyri, also known as the Smith and Ebers papyri. The first papyrus was possibly written by the physician Imhotep around 1500-1600 BC and describes a tumour of the anterior chest. The name cancer was introduced by the Greek Hippocrates of Kos (ca. 460-360 BC), who described ulcerating and non-healing lumps as karkinos, the Greek term for crab, later translated to the Latin word cancer (1). Nowadays, cancer is the name of a collection of around 100 distinct diseases, that are characterized by an abnormal, uncontrolled growth of cells with the potential to invade normal tissue and spread to distant organs (2).

In 2012, there were 14.1 million new cases of cancer and 8.2 million cancer related-deaths, making the disease responsible for every $8^{\text {th }}$ death worldwide $(3,4)$. Cancer is a disease of the genome and develops by stepwise transformation of normal cells to highly malignant derivatives, driven by successive genetic and epigenetic alterations accumulating over the lifetime (5-7). These genetic alterations can include point mutations, amplifications, deletions, or rearrangements that can be inherited, induced by DNA damaging carcinogens, or occur during DNA replication. Epigenetic alterations include DNA methylation and histone modifications. Critical steps in the tumour initiation are activation of proto-oncogenes and inactivation of tumour suppressor genes by genetic alteration. Mutated proto-oncogenes, called oncogenes, are dominant in nature and drive cancer progression by overexpression or hyperactivation. Tumour suppressor genes are recessive in nature and they are either deleted or inactivated on both of the alleles in cancer $(8,9)$. Another class of critical genes involved in cancer development are genes of the DNA repair system. A defect in DNA repair increases the rate of point mutations and chromosomal abnormalities and it is believed that in many tissues, a deregulation of the DNA repair system is needed to develop cancer (10).

Cancer formation follows the Darwinian evolution and the cancer development is based on two processes: continues heritable changes of the genome in individual cells, and natural selection by the environment of the resultant phenotype (2). The process of natural selection fosters cells with an enhanced survival and proliferation compared with the neighbouring cells. Several regulatory circuits control different physiological functions, such as cell proliferation and survival that are cell type and organ specific. These physiological functions are summarised as the "Hallmarks of cancer", proposed by Hanahan and Weinberg in 2000, and include independency to growth signals, insensitivity to anti-growth signals, avoidance of programmed cell death (apoptosis), limitless replication potential, persistent angiogenesis, and invasion and 
metastasis of tissues and distant organs (7). All of these six physiological functions dictate malignant growth and are acquired irrespective of the order by most cancers. Recently, four new characteristics have been added to the traditional six cancer hallmarks proposed by Hanahan and Weinberg, that are avoidance of the immune response, deregulated cellular energetics, tumour promoting inflammation, and genome instability and mutations (11).

\section{Colorectal cancer (CRC)}

Colorectal cancer (CRC) is the third most common form of cancer in men and the second in women worldwide with together around 1.36 million new incidences reported in 2012 (3). About 700000 estimated deaths from CRC, make it the fourth most common cause of cancer related death worldwide accounting for about $8.5 \%$. More than half of the cases (55\%) occurred in developed regions (3). In Sweden, CRC is the third most common cancer amongst men and women and amongst 58726 new cancer cases reported in 2011, 6162 accounted for CRC (12). The incidence rate for colon cancer increased slightly for both sexes between 1980 and 2011, while the incidence for rectal cancer, which represents about $30 \%$ of all CRC cases, was stable $(12,13)$. During the last three decades, the 5-year survival rates increased both in colon cancer (around 7\%) and rectal cancer (around 20\%), and is currently for colon cancer around 65\% and for rectal cancer around 63\% (12). This increase is probably due to earlier diagnosis and improved treatments.

\section{Anatomy of the colon and the rectum}

The large intestine consists of the colon, the rectum, and the anus, and builds the final section of the gastrointestinal tract (Figure 1). The large intestine is starting with the caecum in the right side of the abdomen, where it is connected to the terminal ileum via the ileocecal sphincter, and ends with the anus (14). The large intestine is $1.5 \mathrm{~m}$ in length, with a surface area of around $25 \mathrm{~m}^{2}$ and can be divided in several segments including the caecum, ascending colon, transverse colon, descending colon, sigmoid colon, rectum, and anus $(14,15)$. The colon is located in the peritoneal cavity, while the rectum lies within the pelvis (13). The main function of the colon includes water and electrolyte absorption, as well as short chain fatty acid formation. The rectum mainly stores the faeces (13). Like the rest of the gastrointestinal tract, the large intestine is made out of four layers (Figure 1). The innermost layer is the mucosa, 
which consists of an epithelial layer containing the Lieberkühn crypts and lymphoid nodules and is surrounded by the muscularis mucosae. The next layers are the submucosal containing blood vessels, nerves and connective tissue, and the muscularis externa consisting of two layers of smooth muscle cells. The last layer is built by the serosa, consisting of connective tissue covered with squamous cell epithelium (15).

During the last two decades, there has been a discussion about whether CRC should be considered as one single disease, or three distinct diseases, namely proximal colon cancer, distal colon cancer, and rectal cancer, because of the differences in their embryogenesis, morphology and physiology that might lead to different tumour developments (16-18). The proximal colon, for example, originates from the embryonic midgut and is perfused by the superior mesenteric artery, whereas the distal colon and the rectum originates from the embryonic hindgut and is perfused by the inferior mesenteric artery $(13,18)$. Other differences include the $\mathrm{pH}$ of the produced mucinous, crypt length, apoptotic index, and metabolic protein production (19-23).

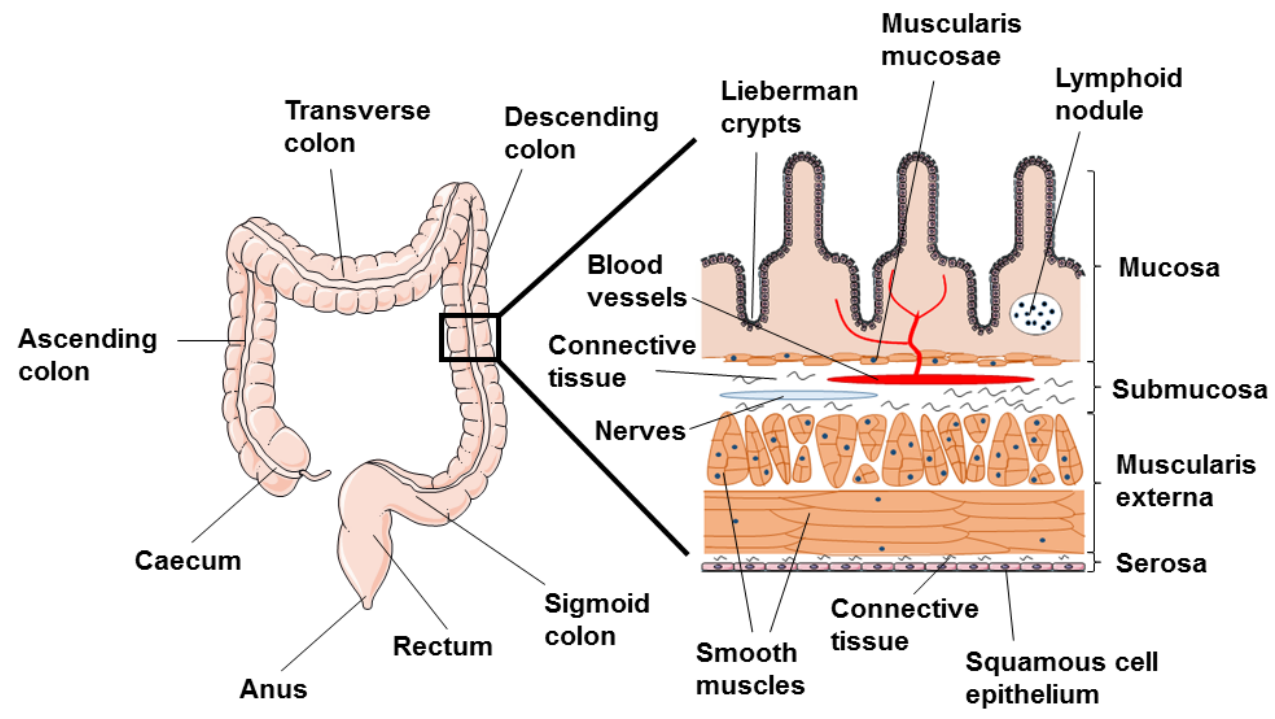

Figure 1. Anatomy of the large intestine and histology of the intestinal wall. 


\section{Risk factors for CRC - sporadic, familial, and hereditary}

Several risk factors for CRC development have been identified which can be divided into two groups: risk factors that can be controlled, including lifestyle and environment, and those that cannot be controlled, such as age and hereditary factors (24). Around 70-75\% of all CRC cases are sporadic without familial or hereditary background, and CRC is therefore considered to be a lifestyle and environmental disease $(25,26)$. Some indications for the importance of the lifestyle and the environment come from migration studies. Japanese offspring who have migrated to the US, showed a similar high CRC incidence as the US population, but a 3-4 times higher incidence compared with the Japanese population (27). A major risk factor for CRC is the diet. It was shown that increased consumption of red meat, and food high in animal fat and fibres increased the risk of developing CRC $(28,29)$. Other lifestyle-related CRC risk factors are low physical activity, obesity, smoking, and high alcohol consumption (24). The likelihood of developing CRC increases with age. In Sweden, around 65-70\% of all the CRC patients are diagnosed when 65 years of age or older. However, the age of diagnosis is decreasing mainly due to lifestyle changes, higher carcinogenic exposure and better diagnostic tools $(12,30)$. Around $20 \%$ of all CRC cases occur in persons with a family history of CRC (31). Individuals with a first-degree relative diagnosed with CRC at age 50 years or older have a 2-3 fold increased risk to develop CRC (32). Furthermore, having one first-degree relative that developed CRC under age 45 years, or having two first-degree relatives diagnosed with CRC, increases the risk to develop CRC by 3-6 fold (33). However, no specific gene loci have been identified in those patients and it is believed that low penetrance susceptibility genes might be involved (34).

Approximately 5-10\% of all CRC cases are connected to highly penetrating inherent mutations (24). The two most common syndromes are called hereditary non-polyposis colon cancer (HNPCC) also known as the Lynch syndrome, accounting for $2-4 \%$ of all CRC cases, and adenomatous polyposis coli, usually called familial adenomatous polyposis (FAP), which accounts for around 1\% $(35,36)$. The molecular basis of HNPCC are germline mutations in the mismatch repair (MMR) genes, that involve in $90 \%$ of the cases the mutS homolog-2 (hMSH2) and mutL homolog-1 (hMLH1) genes (37). Several tools have been developed to identify HNPCC, including analyses of the familial history and age (Amsterdam I and II), microsatellite instability (MSI), and sequences of MMR genes (37-39). Individuals with HNPCC are prone to develop cancer especially in the colon and endometrium in early age (37). 
HNPCC patients develop adenomas in a similar frequency as healthy individuals, but the increased mutation rate results in a faster progression towards malignancy (Figure 2) $(40,41)$. Patients with FAP on the contrary, develop hundreds to thousands of adenomas until their 30s, and due to the large number of adenomas the chance to develop CRC is very high (Figure 2) (42). FAP is an autosomal dominant inherited disease which is characterised by a deletion or mutation of the "gatekeeper" gene adenomas polyposis coli (APC) (43).
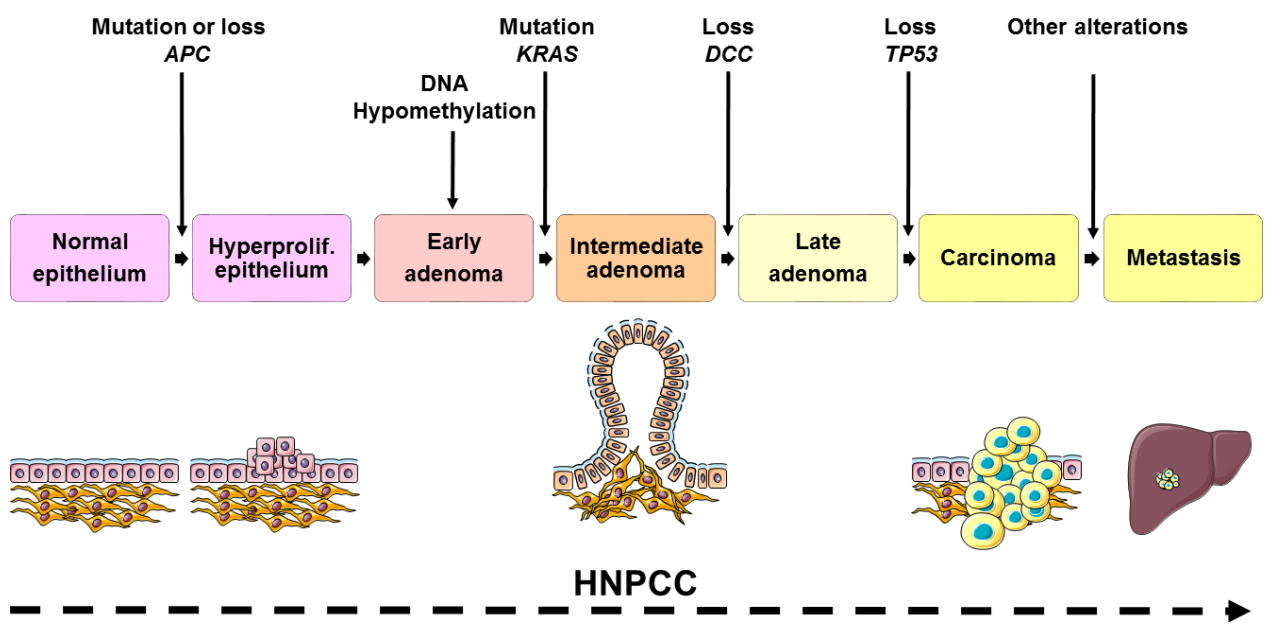

FAP

Figure 2. Sporadic colorectal tumourigenesis is a multistep process. The development of CRC from the normal epithelium to adenoma, carcinoma and finally metastasis is characterised by a series of mutational events in tumour suppressor genes and oncogenes (adapted from Vogelstein and Fearon (9)). HNPCC patients have an increased mutation rate and progress faster towards malignancy, while FAP patients develop a large number of adenomas during their lifetime. 


\section{Colorectal carcinogenesis}

The concept of tumourigenesis as a multistep process, was shown in a model for CRC formation developed by Fearon and Vogelstein in 1990 (9). They described the process of tumourigenesis in three phases: initiation, promotion, and progression from pre-existing adenomas (benign and slow growing tumours), into carcinomas and metastatic disease through specific genetic events (Figure 2). Around $80-85 \%$ of all sporadic CRC follow this pathway that is often referred to as the "canonical" or "suppressor" pathway (36).

The initial step from the normal- to hyper-proliferative epithelium is a result of the activation of the Wnt signalling pathway by the loss or mutation of the $A P C$ tumour suppressor (5q21), found in around $70-80 \%$ of all colorectal tumours $(5,9)$. The canonical Wnt signalling pathway plays a central role in the biology of the colonic crypt. Stem cells in the bottom of the colonic crypt receive Wnt signals from the surrounding stroma cells. These signals stimulate the release of the cadherin-associated protein beta ( $\beta$-catenin) from the APC-axin complex, and prevent $\beta$-catenin phosphorylation by the glycogen synthase kinase 3 beta (GSK-3 $\beta$ ) and subsequent degradation. Subsequently, $\beta$-catenin accumulates in the nucleus, associates with the transcription factor (TCF)/ lymphoid enhancer-binding factor (Lef), and drives transcription of genes involved in cell proliferation. Moreover, it prevents the differentiation of the resulting progenitor cells. While the undifferentiated progenitors migrate upwards to the intestinal lumen, the Wnt signals decrease, and the cells differentiate and stop to proliferate (44). When APC is non-functional due to genetic loss or mutation, GSK-3 $\beta$ will not be able to phosphorylate $\beta$-catenin, and thereby overcomes degradation. This leads to uncontrolled cell proliferation in the intestinal lumen and the formation of adenomas (45).

In the model proposed by Fearon and Vogelstein, the CRC tumourigenesis is driven by DNA hypomethylation, activation of the kirsten sarcoma viral oncogene homolog (KRAS) protooncogene (12q12.1), and loss of function of deleted in colorectal carcinoma (DCC)/ smad family member-4 (SMAD4), smad family member-2 (SMAD2) (18q), and TP53 (17p13.1) tumour suppressor genes (9). However, the described alterations in this model are not restricted to any specific phase of colorectal tumourigenesis and they might appear in a different order (9).

DNA hypomethylations have been detected in CRC, whilst other specific DNA regions show to be hypermetylated (46-48). DNA methylations are covalent modifications of cytosine within $\mathrm{CpG}$ dinucleotides, often organised in larger clusters close to the promoter regions (49). It is known that DNA methylations influence gene transcription, while the exact mechanisms are 
still to be validated (50). DNA methylation patterns are balanced by methylation and demethylation and exposure to carcinogens might interfere with the process, resulting in inhibited tumour suppressor gene expression (51).

KRAS mutations are found in around $30-50 \%$ of all colorectal tumours (52). K-Ras is a member of the Ras family and encodes for a membrane bound $\mathrm{G}$ protein involved in extracellular signal transduction. K-Ras is involved in cell proliferation and survival via the phosphatidylinositol4,5-bisphosphate 3-kinase (PI3K) and mitogen-activated protein kinase (MAPK) signalling pathways (53).

Allelic loss at chromosome 18q has been detected in around $70 \%$ of all CRC cases (54). Among the genes identified at this locus, three have been found to be involved in the CRC tumourogenesis including DCC, SMAD2 and SMAD4. DCC is a transmembrane receptor of the Ig superfamily of netrins, which is believed to be involved in cellular adhesion and apoptosis (55). SMAD2 and SMAD4, both tumour suppressor genes have been found to be mutated in $10 \%$ and $15 \%$ of all colorectal tumours respectively (56). SMADs belong to a family of intracellular mediators and SMAD2 and SMAD4 are important in the anti-proliferative tumour growth factor beta (TGF- $\beta$ ) signalling (57).

The first tumour suppressor gene to be identified was TP53, which is inactivated in around $50 \%$ of all human cancers and in $50 \%$ of all CRC $(58,59)$. The cellular level of the p53 protein is mainly regulated by its degradation via the $M D M 2$ proto-oncogene (MDM2), an E3 ubiquitin protein ligase. Thereby, MDM2 binds to p53 and catalyses its polyubiquitination, a label for proteasomal degradation (60). The MDM2-p53 interaction is regulated by a negative feedback loop, where 533 binds to the promotor region of MDM2, attracts the transcriptional machinery, and initiates its expression (60). A central step in the p53 activation is the destabilisation of the MDM2-p53 interaction, by phosphorylation or acetylation of p53 on the N-terminal MDM2 binding domain $(61,62)$. In the classical tumour suppressor model for $\mathrm{p} 53$, activation occurs in response to DNA damage and cellular stress, such as DNA strand breakage, telomere erosion, and hypoxia. Once activated, p53 binds to the DNA as homodimer of dimers, and regulates the transcription of genes mainly involved in apoptosis and growth arrest (63-65). The majority of cancer-related TP53 mutations (around 85\%) are detected in the DNA binding domain of p53 (66). Interestingly, there is a correlation between the TP53 mutational status and the immunohistological staining of the p53 protein, suggesting a prolonged half-life of the mutant protein (67).

Another pathway, responsible for around 15-20\% of all CRCs, involves the DNA repair apparatus and is referred to as the "mutator" or MSI pathway $(68,69)$. In the 1990s, Perucho 
and his team used a PCR technique with random primer and electrophoretic separation of the products to search for new tumour suppressor genes. Thereby, they compared the amplification signatures of matched DNA samples from colorectal tumours and adjacent normal colonic tissues (70-72). They found deletions in almost all tumours, but detected a slight difference in the electrophoretic migration pattern of some bands in around $12 \%$ of the cases. Further analyses showed that these bands contained small repetitive sequences (microsatellites), mainly consisting of polyadenine (70). Similar findings were achieved by the group led by Thibodeaus, who found mutations in the $[\mathrm{CA}]_{\mathrm{n}}$ sequence in around $28 \%$ of the analysed samples and referred to this phenotype as MSI. Subsequently, several studies have shown that these changes in the repetitive sequences are due to a defect in the DNA MMR system $(68,73)$. In long repetitive sequences such as the microsatellites, the DNA polymerase is prone to incorporate wrong nucleotides, and/or the wrong amount of nucleotides. The function of the MMR system is to detect those errors and repair them. If the MMR system is non-functioning, a wrong incorporated nucleotide can lead to frameshift mutations, which can results in a truncated and non-functional protein (68). Microsatellite sequences have been identified in several genes involved in colorectal carcinogenesis, including genes that regulate cell proliferation, cell cycle, apoptosis, DNA repair, and MMR (74). MSI tumours are classified into MSI-high and MSI-low, depending on the amount of mutated microsatellite marker of a defined panel (75).

\section{Metastasis}

Metastasis is the spread of cancer cells to surrounding tissues and distant organs. Metastases are responsible for around $90 \%$ of all cancer-related deaths and the most common organs for CRC metastases are the liver ( 70\%) and the lungs (10-20\%) (76, 77). Approximately $25 \%$ of all CRC patients have a metastatic disease when the cancer is first diagnosed, and a high number of patients will have undetectable micro-metastases. Moreover, another $25 \%$ of all CRC patients will develop metastatic tumours during the course of the disease (78).

The process of tumour metastasis involves a series of interrelated events that lead to the growth of cancer cells at secondary sites (Figure 3). First, the cancer cells have to detach from the primary tumour and invade into the surrounding tissue through the basement membrane and extracellular matrix (ECM). The detached cells intravasate as they penetrate the lymphatic and/or vascular circulation. In the circulation, the cancer cells have to survive anoikis and shear forces, adhere at the secondary site, and extravasate into the vascular basement membrane and 
ECM. Finally, these cells proliferate at the distant organ and form micro- and macro-metastases (76).

Epithelial cells can invade in a multicellular way as a strand or a cluster. However, single migrating and invading cells are often observed (79). Characteristic for these single migrating and invading cells are the loss or change of their polarisation, cell-cell and cell-ECM adhesion, and a mesenchymal like morphology. This cellular change is called epithelial to mesenchymal transition (EMT), and was first described by Lillie in the 1900s in chickens (80, 81). EMT can be induced by different signals including TGF- $\beta$, endothelial growth factor (EGF), and hypoxia, and involves the deregulation of E-cadherin, pro-migratory small GTPases and transcription factors (82-84).

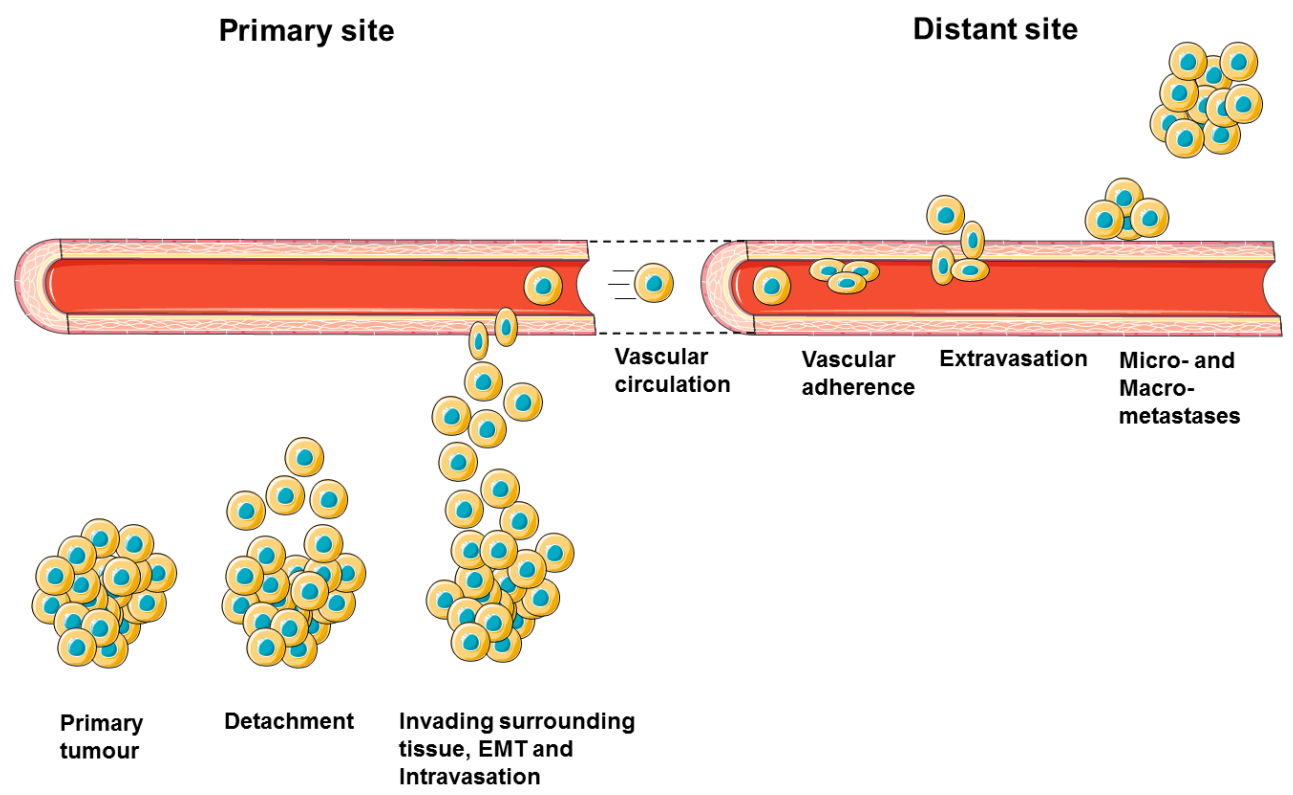

Figure 3. Interrelated events lead to tumour metastasis. From left to right: tumour cell detach from the primary tumour, invade the surrounding tissue through the basement membrane and extracellular matrix (ECM), and some of the single migrating cells perform epithelial to mesenchymal transition (EMT). Invading cells intravasate as they penetrate the lymphatic and/or vascular circulation, and adhere to the vascular wall at the secondary site where they extravasate into the vascular basement and ECM. At the distant site, the cells might grow to micro- and macro-metastases. 
Changes in the cell-cell and cell-matrix adherence are important in the detachment of the cells from the primary tumour and in invasion, intravasation and extravasation (85). Cell-cell signalling and adherence in endothelial cells are mainly accomplished by cell junction complexes consisting of tight junctions, gap junctions, adherence junctions, and desmosomes (86). Tight junctions act as semipermeable gates for ions, water, solutes, and cells, between the lumen and the extracellular space (87). Gap junctions are intercellular channels that control diffusion of ions and small molecules, and are mainly composed of connexins, a family of transmembrane proteins (88). Adherence junctions and desmosomes substantially contribute to cellular adherence and motility. The adhesion in these junctions is accomplished by factors called cell adherence molecules (CAMs). CAMs can be divided into four main groups: cadherines, immunoglobulin superfamily, selectins, and integrines, and are often found to be deregulated in epithelial cancers $(86,89-93)$.

Once detached from the tumour, single cells are able to migrate and invade within the tissue. The tumour cell migration and invasion are multistep processes, similar to events found during embryonic morphogenesis, wound healing, and immune-cell trafficking (79). First, the migrating cell changes its shape and becomes polarised and elongated. A finger-like protrusion called pseudopod is formed at the leading edge and interacts with the ECM via focal contacts. These focal contacts consists of the CAM integrin that binds the ECM intercellular and intracellular actin filaments via a multi-protein complex. In the next step, pro-proteases like matrix metalloproteinase (MMP) 1, 2, and 9 are recruited to the focal contacts. Activation of the MMPs leads to focalised proteolysis of specific parts of the ECM that generates a track for the cell (94). The movement of the cell is then facilitated via actomyosin contraction. In the last step, the focal contacts at the trailing edge are dissembled and recycled (79).

The MMPs have been of special interest during the last years. It was shown in multiple studies that the expression of MMPs increased substantially in the majority of malignant tumours compared with their normal counterpart (95-99). MMPs consist of 18 structurally related members of zinc endopeptidases that are either secreted or membrane bound (94). The expression of MMPs is induced by a variety of signals, including cytokines, growth factors, and cell-cell and cell-ECM interactions (100-103). Most MMPs are secreted into the intercellular space and proteolytically activated by cleaving of the pro-peptide and exposing the catalytic site (104). Inhibitors of MMPs, called tissue inhibitors of metalloproteinases (TIMPs), are able to bind MMPs intercellular, and inhibit their activation or activity (103). MMPs are involved in intravasation, extravasation, metastasis, neovascularisation, and tumour growth (105). Many pharmacological studies were aimed to develop drugs to inhibit cellular 
migration and invasion by blocking MMPs; however, those inhibitors have failed and it remains a challenging task to achieve therapeutically meaningful outcomes by targeting these proteins (106).

Once the invaded cells reached a blood vessel, they intravasate by facilitating molecular changes and interactions with macrophages, allowing them to pass the endothelial cell barrier. Tumour-associated blood vessels, built during tumourigenesis, are likely to facilitate the intravasation due to their poor architecture and the lack in epithelial adherence (107). Arrived in the blood circulation the cells can disseminate widely throughout the body. However, to be able to survive in the circulation, the tumour cells have to overcome several barriers like anoikis and the stress from shear forces (108).

When the microvasculature of distant organs is reached by the disseminated cells, they attach at the vascular wall, proliferate, and extravasate $(109,110)$. However, the architecture of the epithelium in these vessel is highly functional and the exact mechanisms of penetration is probably different compared with the intravasation (111). Several factors have been identified that disturb the vessels, induce permeability, and subsequently allow the cells to invade. These factors are secreted from the cancer cells and include, among others, angiopoietin-like-4 (Angptl 4), angiopoietin-like-2 (Angptl 2), vascular endothelial growth factor (VEGF) and several MMPs (107).

Once the cells are in the distant organ parenchyma, they face a foreign microenvironment, consisting of different growth factors, ECM constituents and different types of stromal cells, in which they have to survive and persist. The cells often survive as micrometastases in the new environment, without significant increase in size and net gain or loss in overall cell number. These micrometastases can sustain for up to several years before growing to detectable macrometastases $(112,113)$.

During all steps of metastasis, the cells are attacked by the immune system. However, by interacting with tumour-associated macrophages, tumour-associated neutrophils, myeloidderived suppressor cells, and regulatory $\mathrm{T}$ cells, the cancer cells can survive the journey to the distant site thought different mechanisms, including the suppression of natural killer cells and cluster of differentiation 8-positive $\left(\mathrm{CD}^{+}\right) \mathrm{T}$ cells (114).

Several studies indicated that there is a preference of organs for metastases, dependent on the origin of the primary tumour (110). Already in the 1880s, Paget proposed the hypothesis that the interactions of the tumour cells with their environment prone the cells to metastasise to certain organs with a similar (approved) environment. This postulation is also known as the "seed and soil" hypothesis, meaning that the seed (the tumour cells) can only grow when the 
soil is compatible (milieu of certain organs) (115). Today, some studies suggest that pre-metastatic niche, induced by cells of the immune system, prime the tumour cells to metastasise to a certain organ (116). However, the cells have to make several adaptions, even in similar environments to be able to sustain in the foreign tissue.

\section{Prognosis and prediction}

Prognosis is the medical term used to indicate the probable course and outcome of a disease and may give an estimation for the aggressiveness of a cancer. It is widely measured by the probability to stay alive or without disease recovery for a certain amount of time after the cancer diagnosis, or the start of an adjuvant treatment. A threshold of five years is commonly used for the survival or cancer re-growth, but depending on the treatment and disease, shorter or longer time periods might be considered (117). The best estimation for prognosis in CRC is the pathological stage. Several staging systems have been developed during the years. In the 1930`s, Dukes established a staging system for rectal cancer (later applied also to colon cancer) that included three stages: stage A, in which the tumour growth is limited to the wall of the rectum with no metastases in the lymph node; stage $B$, in which the tumour extend into the extrarectal tissue without metastases in the regional lymph nodes; stage $\mathrm{C}$, in which the tumour has spread to the regional lymph nodes (118). Later Turnbull et al. added stage D for tumours with distant metastases (119). A more differentiated staging system was introduced by the American Joint Committee on Cancer (AJCC) based on the local tumour depths of invasion (T1-4), the presence and amount of lymph node metastases (N0-2), and the presence of distant metastases (M0-1) (120). Today, the clinicians use the $7^{\text {th }}$ version of the TNM staging published in 2009 (Table 1) (121). In addition to the tumour stage, other prognostic factors for CRC have been discovered such as blood or lymphatic vessel invasion, surgical margins, and tumour grade (well-, moderately-, poorly- or un-differentiated) (122). Tumour staging, together with these histopathological features, give rather good estimations of the likely course of the disease. However, no or little information about the outcome of a treatment is offered by these factors (123).

In the last several years, the attention has been focused on the identification of biological characteristics with improved prognostic and especially predictive values. These biological characteristics, also called biomarker, include genetic and epigenetic alterations, mRNA and protein expression, and posttranslational modifications (123). 
Table 1: Dukes and TNM classification for CRC ( adapted from Engstrom et al. (124) and Edge et al. (121)).

\section{Dukes Stage grouping and staging TNM staging system}

Prognosis

(5 year)

\begin{tabular}{|c|c|c|c|c|}
\hline- & 0 & Tis, N0, M0 & Tis: Tumour in situ & \\
\hline \multirow[t]{2}{*}{ A } & I & T1, N0, M0 & $\begin{array}{l}\text { T1: Tumour has grown through the } \\
\text { muscularis mucosa into the submucosa } \\
\text { N0: No regional lymph node metastasis } \\
\text { M0: No distant metastasis }\end{array}$ & $\sim 92 \%$ \\
\hline & & T2, N0, M0 & $\begin{array}{l}\text { T2: Tumour has grown into the } \\
\text { muscularis externia }\end{array}$ & \\
\hline \multirow[t]{3}{*}{ B } & IIA & T3, N0, M0 & $\begin{array}{l}\text { T3: Tumour has grown through the } \\
\text { muscularis externia into the serosa }\end{array}$ & $\sim 82 \%$ \\
\hline & IIB & T4a, N0, M0 & $\begin{array}{l}\text { T4a: Tumour has grown through the } \\
\text { serosa }\end{array}$ & \\
\hline & IIC & T4b, N0, M0 & $\begin{array}{l}\text { T4b: Tumour has grown through the } \\
\text { serosa and is attached, or invades } \\
\text { other organs }\end{array}$ & \\
\hline \multirow[t]{3}{*}{$\mathrm{C}$} & IIIA & $\begin{array}{l}\text { T1, T2, N1, M0 } \\
\text { or } \\
\text { T1, T2, N2a, M0 }\end{array}$ & $\begin{array}{l}\text { N1: Metastasis in one-three regional } \\
\text { lymph nodes } \\
\text { N2a: Metastasis in four-six regional } \\
\text { lymph nodes }\end{array}$ & $\sim 60 \%$ \\
\hline & IIIB & $\begin{array}{l}\text { T3-T4a, N1, M0 } \\
\text { or } \\
\text { T2-T3, N2a, M0 } \\
\text { or } \\
\text { T1, T2, N2b, M0 }\end{array}$ & $\begin{array}{l}\mathrm{N} 2 \mathrm{~b} \text { : Metastasis in more than seven } \\
\text { regional lymph nodes }\end{array}$ & \\
\hline & IIIC & $\begin{array}{l}\text { T4a, N2a, M0 } \\
\text { or } \\
\text { T3-T4a, N2b, M0 } \\
\text { or } \\
\text { T4b, N1-N2, M0 }\end{array}$ & & \\
\hline \multirow[t]{2}{*}{$\mathrm{D}$} & IVA & AnyT, Any N, M1a & M1a: Metastasis in one distant organ & $\sim 8 \%$ \\
\hline & IVB & AnyT, Any N, M1b & $\begin{array}{l}\text { M1b: Metastasis in more than one } \\
\text { distant organ }\end{array}$ & \\
\hline
\end{tabular}


A prognostic biomarker provides information, about the patients overall outcome and can be useful to select for a certain treatment. A predictive biomarker provides information, about the likelihood to response to a clinical treatment $(123,125)$. So far, there are only few biomarkers used in the routine clinical practice for CRC and most of them include genetic markers. The prognostic and predictive value of mutations in the KRAS and neuroblastoma RAS viral oncogene homolog (NRAS) gene at the codons 12 and 13 (exon 2) as well as 61 (exon 3) have been evaluated in several studies. It was shown that patients with a mutation in KRAS have a significant lower benefit from endothelial growth factor receptor (EGFR) target therapy with the monoclonal antibodies cetuximab and panitumumab (126-128). Similarly, patients with a mutation in the B-Raf proto-oncogene $(B R A F)$ did not respond to the anti-EGFR treatment (129). EGFR is thought to signal via the Ras-Raf-MAPK signalling pathway, leading to proliferation. Mutations in $K R A S$ or $B R A F$ genes leads to the constative activation of this signalling pathway and the upstream inhibition of EGFR in patients with KRAS or BRAF mutated tumours has no effect (130). Moreover, a MSI-high genotype in CRC has been shown to have both a prognostic value and a predictive value for 5-Flourouracil treatment $(131,132)$. However, intratumoural (different types of cell clones within a tumour) and intertumoural (differences between tumours of different patients) heterogeneity make treatment predictions very challenging $(133,134)$. Several clones within a tumour might be eradicated by a certain treatment, while other clones might be resistant against the same treatment. Whether the cell is resistant to a certain treatment depends thereby on several factors (like the KRAS and BRAF mutations for anti-EGFR treatment), which might be different within the tumour, and differ among patients. The personalised treatment, based on the specific tumour phenotype and genotype, is considered as the future in oncological treatment, also called personalised treatment. However, to be able to treat cancer in a personalised setting, more knowledge about resistance mechanisms, as well as more precise predictive and prognostic biomarkers are needed (135). 


\section{Treatment}

The choice for the optimal treatment for CRC patient's dependents on several factors, including tumour location, stage, genotype for $R A S$ mutations and recurrence. The treatment options can be mainly categorised in four groups: surgery, chemotherapy, radiotherapy (RT), and targeted therapy. The main goal of all anti-cancer treatments, apart from surgery, is the decrease in tumour growth and ultimately its eradication. It has been postulated that most cancers are hierarchically organised, containing a few cells that act as cancer stem cells (CSCs). These CSCs have the same characteristics as the normal stem cells including, self-renewal and differentiation, and sustain the cancer (136). It is thought that CSCs have to be targeted to be able to successfully eradicate the tumour (137).

\section{Surgery}

The main goal of CRC surgery is to curatively remove the tumour-bearing bowel segment in order to restore the bowel continuance and assure the best quality of life for the patient (138). For locally resectable colon cancer, the preferred surgical technique is colectomy with removal of regional lymph nodes, en bloc if possible. The location of the tumour dictates whether only a part of the colon (left or right sided hemicolectomy) or the entire colon (subtotal or total colectomy) is resected (124). Total colectomy is considered if the patient has a synchronous tumour (left and right colon) or if the patient is diagnosed with FAP or HNPCC (139). For rectal cancer, the type of surgery depends on the localisation and stage of the tumour. Early stage rectal cancer can be removed by polypectomy, transanal local excision or, for selected tumours, by transanal endoscopic microsurgery (124). For more advanced tumours, which do not meet the criteria for local surgery, a transabdominal resection is performed. The surgical method of choice for transabdominal resection is the total mesorectal excision (TME), with removal of the mesorectum including vasculature, lymphatic structures, and fatty tissue en bloc, through sharp dissection with preservation of the autonomous nerves. An abdominoperineal resection, including the resection of the rectosigmoid, the rectum, and the anus, is performed when the tumour involves the anal sphincter of the lavatory muscle (140). The pelvic localisation of the rectum complicates the total removal substantially. To be curative, the margins of resected tissue must be tumour-free and any organs or structures attached to the tumour must be resected en bloc. Therefore, skills of the surgeon have a major impact on the outcome of the surgery (138). 


\section{Chemotherapy}

To reduce the risk of recurrence after surgery, adjuvant chemotherapy is given to both colon and rectal cancer. In rectal cancer, chemotherapy is given together with RT as a neo-adjuvant treatment to reduce the tumour size before surgery. For unresectable CRC, chemotherapy is used as a palliative care to reduce suffering and pain, and to prolong life. Many chemotherapeutic agents target cycling cells with the rational that cancer cells replicate more frequent. One strategy to inhibit cell growth is to target the DNA, thereby inhibiting the replication that eventually results in apoptosis or necrosis. The main chemotherapeutic agents used for CRC treatment are 5-fluorouracil (5-FU in combination with folinic acid), leucovirin, capecitabine, oxaliplatin and irinotecan $(124,140)$.

5-FU and capecitabine are both metabolised in vivo to a monophosphate derivate. These build a complex with the thymidylate synthase and block the function of the enzyme. As a result, the pool of deoxythymidine monophosphate, a building block of the DNA, is reduced, while deoxyuridine monophosphate is increased in the cell. This inhibits DNA replication and cell division, and leads consequently to DNA damage. A strategy to increase the effect of 5-FU is to increase the duration of the monophosphate derivate binding to the thymidylate synthase. One way to do this is to increase the levels of the cofactor 5, 10-methylene-tetrahydrofurane. In a clinical setting 5-FU is given together with folinic acid or leucovirin, which are converted to 5,10-methylene-tetrahydrofurane in vivo (141).

Oxaliplatin is a platinum based chemotherapeutic with a 1, 2-diaminocyclohexane (DACH) carrier. Oxaliplatin binds to guanine in the DNA and forms DNA intra- and inter-strand crosslinks that disturbs DNA replication and eventually lead to apoptosis (141). The pro-drug irinotecane is converted in vivo to $\mathrm{SN}-38$, which binds and inhibits the DNA topoisomerase I (Top1) that is part of the DNA replication complex and catalyses the DNA unwinding and reannealing. The binding of SN-38 to Top1 inhibits the reannealing of the DNA, leading to the collusion of the DNA replication complex with the replication fork and consequently results in replication stop and DNA double-strand breaks (DSB) (142).

Several combinations of the above mentioned chemotherapeutics are applied to increase the effect and overcome possible resistances. The most common combinations are 5-FU, leucovorin and oxaliplatin (FOLFOX); 5-FU, leucovorin and irinotecan (FOLFIRI); and capecitabine and oxaliplatin (CapeOx) $(124,140)$. Unfortunately, chemotherapy is not tumour cell specific and therefore has a number of side effects including hair loss, nausea, vomiting, and low blood counts. 


\section{Radiotherapy (RT)}

As for chemotherapy, the DNA is the main molecular target for RT. Since the discovery of the X-rays by Röntgen in 1895 and the natural radioactivity by Becquerel in 1896, radiation has been used in multiple medical applications (143). Grubbé was the first to treat cancer (breast cancer) with the newly discovered x-rays in 1896 (144). Nowadays, RT for rectal cancer is applied by an external beam consisting of $\gamma$-rays, electromagnetic high-energy radiation produced by a linear accelerator. These waves or photons have the ability to remove electrons from atoms and are therefore called ionising radiation. The biological effect of radiation is mainly attributed to the effect on the DNA, even though radiation also affects membranes and proteins. The DNA can be damaged directly by the photons, but mainly indirectly by freeradicals, produced in the near surrounding of the DNA. The resulting damages of the DNA include base/sugar damage, single-strand breaks and DSB all of which can be clustered in complex DNA damaging sites (145). However, the cytotoxic effect is mainly due to the DNA DSB. When DNA DSB occur, the cell is arrested in the cell cycle via the activation of the kinases ataxia-telangiectasia-mutated (ATM) or ataxia-telangiectasia and Rad3 related (ATR), and subsequent reduced cyclin-dependent kinase activity leading to $G_{1}-S$, intra $S$, and $G_{2}-M$ cell cycle arrest (146). DNA DSB lesions are repaired by either of two DNA DSB repair mechanisms: the fast, but error prone, non-homologues end joining, or the slow, but more precise, homologues recombination. Damages too complex to be repaired lead to chronic DNA damage signals that trigger cell death by apoptosis or senescence (146).

In the 1920s, it was shown that the effect of radiation on cell growth has a bigger effect when given in small daily fractions over days instead of a single dose. Later it was generally accepted that the patient outcome improves with fractionated doses $(147,148)$. The success of fractionated treatment can be described by the 4 R's of radiobiology, Repair of sublethal DNA damage, Redistribution of the cells in the cell cycle, Reoxygenation of previously hypoxic areas, and cell Repopulation (149).

The amount of repaired sublethal damage after radiation is depending on the ability of the cell to activate their repair mechanisms and to induce cell cycle arrest. In many cancer cells, DNA repair and cell cycle control pathways are deregulated, making those cells more sensitive to radiation (150). Furthermore, the sensitivity depends on the phase of the cell cycle in which the cell is at the time of radiation. Cells in the S-phase have been shown to have the highest survival after radiation, whereas cells in the G2 or M phase are most sensitive. The fractionated treatment allows the cells to repair their damage, move through the cell cycle and be "hit" in a 
more sensitive cell cycle phase. Due to the increased proliferation rate of cancer cells, this effect will be higher in cancer tissue than in the normal tissue (151). The influence of oxygen on cell survival upon radiation has already been observed as early as 1904 by Hahn (152) and Schwarz (153). Under hypoxic conditions, the effect of radiation on the survival of cells can be 2-3 times higher compared with oxygenated cells. Tumours usually have hypoxic areas due to poor vascularisation and vascular architecture, therefore a single dose of radiation would have a lower effect in these areas. However, angiogenesis is induced after radiation and former hypoxic areas in the tumour become re-oxygenated, and sensitivity will increase for the following fractions (154). Radiation leads to a massive loss of cells, but triggers the proliferation of surviving CSC that repopulate the tumour. The amount of newly produced cells after radiation can even exceed the amount of cells before the treatment and therefore, it is important to eradicate all CSCs within the tumour (155).

Later, the intrinsic Radiosensitivity of the different types of cancer was suggested as the $5^{\text {th }} \mathrm{R}$ of radiobiology (150). The intrinsic radiosensitivity is depending on factors regulating mainly DNA repair, cell cycle progression, and apoptosis.

In the last 40 years, several European trials showed a reduced local recurrence rate for rectal cancer patients after neoadjuvant RT (156-160). The Swedish rectal cancer trial was one of two big European clinical trials evaluating the benefit from short-course preoperative radiotherapy treatment for rectal cancer. The Swedish rectal cancer trial was the first and only study to show a significant decreased local recurrence and an improved overall survival after preoperative RT $(156,161)$. However, a Dutch group using the same treatment regime, though performing TME, confirmed the decrease in local recurrence, yet could not show an increased overall survival (157). Thereafter, several clinical trials evaluated whether pre- or post-operative RT given in a short- and in a long-course in combination with chemotherapy could achieve a better outcome $(159,160,162)$. Two systems of RT have shown clear clinical evidence with improved local control and sphincter preservation: preoperative short-course RT and preoperative long-course chemoradiotherapy $(161,163)$. The administered radiation dose and the time interval depends on the stage and localisation of the tumour. Primary resectable tumours are usually treated by a short-course preoperative RT. A total dose of $25 \mathrm{~Gy}$ is given in five fractions over one week followed by surgery within one week. For primary nonresectable tumours, the long-course chemoradiotherapy is generally used. The given dose is between 45-50 Gy in 25 fractions over five weeks, followed by surgery after a gap of six to 10 weeks, whenever possible (164). Although, improved radiation margins, resulting from higher resolution imaging, and radiation from different angles, leading to a dose maximum in the 
tumour, has decreased the dose deposited in the normal tissue, there are still many side effects from radiation in rectal cancer (165). Moreover, there is a wide variation in the response to RT in rectal cancer and many patients experience recurrence, especially distant recurrence due to differences in the intrinsic radiosensitivity (166). A big challenge is to find factors that enable to select for patients that will benefit from the treatment and/or need an alternative treatment. Some factors have been identified that have the potential to predict the radiation outcome in rectal cancer including p53, p21, and survivin, but those factors have not been evaluated for a clinical application $(166,167)$. Furthermore, more markers are needed to account for the big variety between the different patients and tumours.

\section{Targeted therapy}

Research on the molecular basis of $\mathrm{CRC}$, and thereby increased knowledge about the pathophysiological mechanisms leading to $\mathrm{CRC}$, brought in the new area of targeted therapy. Targeted therapy includes monoclonal antibodies and small-molecular drugs that are designed to target a specific molecule. Today, there are at least three monoclonal antibodies in clinical use against $\mathrm{CRC}$ often combined with chemotherapy. The monoclonal antibodies cetuximab and panitumimab inhibit EGFR by binding to its extracellular domain and thereby blocking its activation, whereas the antibody bevacizumab is designed to inhibit VEGF (168). Additionally, several antibodies against important signalling pathways in CRC have been developed, including the $\mathrm{Wnt} / \beta$-catenin and Nuclear factor- $\kappa \mathrm{B}(\mathrm{NF}-\kappa \mathrm{B})$, and are under evaluation in clinical trials (169).

\section{Treatment-enhanced metastasis}

All cancer treatments currently used in clinical practice including surgery, chemotherapy, and RT have proven their effect in large clinical trials including several hundreds to thousands of patients, but they may also create phenotypes and niches that facilitate metastatic spread (170). Already in the 1940s, it was shown in a mouse model that radiation of a subcutaneous tumour resulted in size reduction, but increased metastases in the lungs (171). Since then, several studies have analysed the effect of radiation-enhanced metastasis, mainly using in vitro cell culture models and in vivo mouse models. Two distinct effects have been established: increased localisation of metastases in radiated tissue, and increase in metastases upon local tumour radiation $(170,172,173)$. 
The effect of increased metastasis in radiated normal/secondary tissue has been observed in patients, and was studied in mouse models $(173,174)$. It was observed that a dose related aggregation of cancer cells at the radiated tissue is increased immediately after radiation, but sometimes also months later (173). Possible mechanisms for this effect could be localised immunosuppression by reduced natural killer cell activity or local tissue damage at the radiated site leads to extracellular re-modelling and formation of a pre-metastatic niche (175-178). Increased metastasis upon local tumour radiation has been observed in several models. Many mechanisms have been postulated, including direct alterations of the tumour cell activities and changes of the local normal tissue containing tumour associated cells at the tumour site (172, 173, 179).

Countless studies have been performed in cell lines and mouse models showing the activation of several signalling pathways involved in invasion and metastasis, upon direct radiation of cancer cells $(172,179)$. One important observation was the morphological change of irradiated cancer cells that showed a mesenchymal phenotype typical to EMT. Several signalling pathways in different cell types have been found to induce EMT upon radiation, including $\mathrm{NF}-\kappa \mathrm{B}, \mathrm{TGF}-\beta, \mathrm{PI} 3 \mathrm{~K} / \mathrm{v}$-akt murine thymoma viral oncogene homolog (Akt)/ mechanistic target of rapamycin (mTOR), and granulocyte colony-stimulating factor receptor (G-CSFR)/ Janus kinase-1 (JAK1) / Signal transducer and activator of transcription 3 (STAT3) (180-184). Another important observation was the increased MMP expression and secretion (especially MMP-2 and MMP-9) after radiation both in experimental models as well as in patients (185188). Many studies showed that knockdown and inhibition of MMP-9 could abolish the radiation-enhanced invasion $(187,188)$. However, similar studies on MMP-2 did not show any effect on radiation-enhanced invasion, but it was shown that the phosphatase and tensin homolog (PTEN) status might be of importance $(187,189,190)$. The MMP secretion was linked to the activation of the PI3K/Akt signalling pathway and subsequent NF- $\mathrm{KB}$ or mTOR activation $(188,189)$. Moreover, several other signalling pathways have been identified that are involved in radiation-enhanced invasion, including insulin-like growth factor receptor-1 (IGFR-1) and subsequent PI3K/Akt, ras homolog family member A (RhoA) and Rhoassociated kinase (Rock) activation, K-Ras and c-Raf and ATM-NF- $\mathrm{B}$ B-MET proto-oncogene (MET) (190-192).

Tumours are heterogeneous masses of cells consisting of tumour cells and tumour-associated cells and radiation has been shown to stimulate tumour-associated cells to boost the invasion of the tumour cells. However, radiation often acts as a double-edged sword on the tumourassociated cells. Blood vessels supply the tumour with important cytokines, nutrients and 
oxygen, and represent gates for the tumour cells to reach out to the rest of the body. Radiation has an apoptotic effect on endothelial cells of the blood vessels and therefore an anti-angiogenic effect. However, there are several pro-angiogenic factors released by the tumour cells upon radiation including VEGF and nitric oxide synthase (NOS) that stimulate the formation of new blood vessels (193-195). The pro-angiogenic effect of the radiated cancer cells might counteract the endothelial cell death (179). Similar is the effect on the inflammatory and immune system. Radiation kills the pro-metastatic macrophages and leukocytes present in the tumour environment, but induces inflammation $(114,179)$. Pro-inflammatory factors released by lymphocytes, including tumour necrosis factor alpha (TNF- $\alpha$ ) and interleukin-1 (IL-1), recruit leukocytes and macrophages to the radiation site and increase the blood vessel permeability $(179,196)$.

\section{Astrocyte elevated gene-1 (AEG-1)}

Astrocyte elevated gene-1 (AEG-1), was originally identified as a human immunodeficiency virus-1 (HIV-1), gp120 and TNF- $\alpha$ inducible gene in human foetal astrocytes by Fisher et al. in 2002 (197, 198). Thereafter, other groups using different experimental settings identified AEG-1 as a protein localised at tight junctions (199) and the nucleus (200), and called it lysinerich CEACAM1 co-isolated (LYRIC) and 3D3/LYRIC, respectively. Another study attempted to identify cell surface molecules that mediate metastasis from mouse breast cancer, found a domain of LYRIC involved in lung metastasis and that protein was named metadherin or MTDH derived from metastasis adhesion protein (109).

The gene coding for AEG-1, called MTDH, comprises of 12 exons/11 introns, and is located at chromosome 8q22 (201). The AEG-1 mRNA consist of 7667 nucleotides with a large 3'untranslated region [GeneBank reference sequence NM_178812.3]. The gene encodes for a lysine-rich, highly basic 582 amino acid protein with a molecular mass of $64 \mathrm{kDa}$ and a halflife of about $20 \mathrm{~h}$ (201-203). Northern blot analyses indicated multiple AEG-1 transcripts and Western blot analyses revealed several proteins with a molecular mass ranging from 65 to 80 $\mathrm{kDa}$ and 35 to $20 \mathrm{kDa}$, possibly due to alternative transcription starting sites, alternative splicing, and/or post-translational modifications, like ubiquitination $(201,203)$. The protein contains several predicted domains and motifs, including a transmembrane domain (amino acid (aa) 51-72) and three nuclear localisation signals (NLS-1, NLS-2, NLS-3; aa79-91, 432-451, and 561-580, respectively; Figure 4) (109, 199-201). The membrane topology of AEG-1 was considered both type Ib and II, both single membrane spanning proteins, but with a different 
orientation. Class I proteins have the $\mathrm{NH}_{2}$ - terminus exposed to the exterior site and the $\mathrm{COOH}$ terminal exposed to the cytoplasmic site, while it is the other way around for class II proteins $(109,199)$. The three NLS are shown to have different functions in coordinating the localisation of AEG-1. The NLS-1 has been shown to primarily regulate the nucleolar localisation, NLS-3 the nuclear localisation, and the NLS-2 the cytoplasmic localisation (203). Additionally, several protein-protein interaction sites have been discovered, including CREP binding protein (CBP, aa 1-70), yin-yang-1 (YY1, aa 71-100), BRCA2 and CDKN1A interacting protein alpha (BCCIP $\alpha$, aa 72-169), NF-кB (aa 101-205), staphylococcal nuclease and tudor domain containing-1 (SND1, aa 101-205 and aa 386-470), a lung homing domain (aa 378-440), and promyelocytic leukaemia zinc finger (PLZF, aa 487-582) (109, 204-208). Furthermore, several post-translational modification sites were predicted, including phosphorylation, ubiquitination, and acetylation, while only the phosphorylation of AEG-1 at Ser298 was experimentally validated and showed biological significance $(209,210)$.

The protein has been localised in the cell membrane, cytoplasm, endoplasmic reticulum, nucleus and nucleolus $(200,201,203)$. However, the biological significance of AEG-1 at the varying locations is not clearly understood.

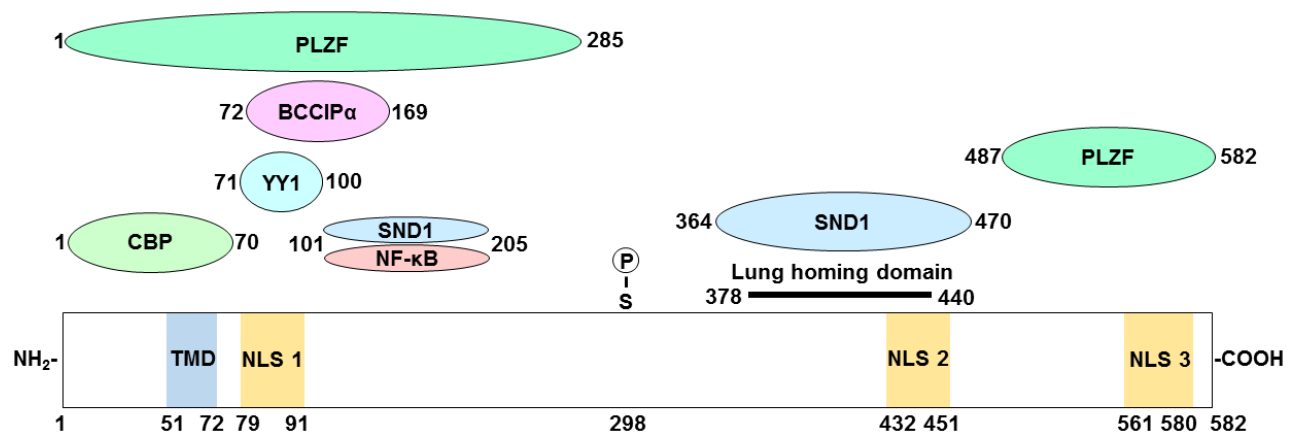

Figure 4. Schematic overview of the AEG-1 protein with functional regions and protein binding sites (adapted from Emdad et al. (211)).

Since AEG-1 has been identified as a metastasis mediating factor in 2004, it has become an intensively studies molecule in the context of cancer (109). The AEG-1 mRNA and/or protein expression has been intensively analysed in a large variety of cancers, including oesophageal squamous cell carcinoma (212), gastric cancer (213), CRC (214), hepatocellular carcinoma (HCC) (202), non-small cell lung cancer (NSCLC) (215), neuroblastoma (216), breast cancer 
(217), prostate cancer (203), and renal cell carcinoma (218). In these studies, the AEG-1 expression was markedly increased in the tumour tissue compared with the matched nonneoplastic tissues, and gradually increased as the disease progresses. In ovarian cancer, an AEG-1 exon 11 skipping variant was detected at higher levels in the cancer tissue compared with benign ovarian epithelial cells (219). Sequencing analyses in blood samples from breast and ovarian cancer patients identified two polymorphisms in the $M T D H$ gene (c.1353G>A, rs2331652, and c.1679-6 T>C) connected with breast cancer susceptibility and one (-470 G>A) with ovarian cancer susceptibility $(220,221)$. However, whether mutations in $M T D H$ attenuates the protein function or are of importance in cancer development have not been validated.

The impact of AEG-1 up-regulation has been evaluated in multiple studies, and it was shown that AEG-1 mediates oncogenesis via the regulation of cell survival, proliferation, anchorage independent growth, migration, invasion, metastasis, chemoresistance, radioresistance, and angiogenesis (222). Furthermore, high AEG-1 expression correlated with a worse patient outcome in most of the studied cancers (223). The expression of AEG-1 can be deregulated by several ways in cancer. Studies in breast cancer and HCC have linked genomic amplification of AEG-1, common for chromosome 8q22, with increased AEG-1 expression (202, 224). Another process called RNA interference (RNAi) has shown to regulate the expression of AEG-1. Thereby, small 21-25nt long RNA molecules called micro RNAs (miRNA), bind to the mRNA, and either inhibit expression or initiate degradation (225). Several of these miRNAs have been identified that target AEG-1 including miR-375, miR-217, miR-153, miR-136, miR30a, and miR-26a (226-232). It has been furthermore shown that the binding of the cytoplasmic polyadenylation element binding protein-1 (CPEB1) to the 3'UTR of the AEG-1 mRNA increases translation, while monoubiqitination of the AEG-1 protein increases its stability in cancer $(203,233,234)$. In 2006, Lee et al. (235) published the first activation pathway of AEG-1, in which AEG-1 was activated by the Harvey rat sarcoma virus oncogene (Ha-Ras) through the PI3K/Akt signalling pathway leading to the binding of the cellular myelocytomatosis oncogene (c-Myc) to the MTDH promoter (Figure 5). Activation or upregulation of any of these components can also increase the expression of AEG-1.

So far, many downstream signalling pathways activated by AEG-1, as well as interacting proteins, have been discovered by which AEG-1 exerts its oncogenic function (Figure 5). The first discovered signalling pathway was the NF- $\kappa B$ pathway. The NF- $\kappa B$ transcription factor family consists of important mediators for inflammation processes, immune and stress responses, and apoptosis. The NF- $\mathrm{BB}$ proteins consists of different heterodimers which can be 
activated via two signalling pathways: the canonical and the non-canonical pathway. In resting

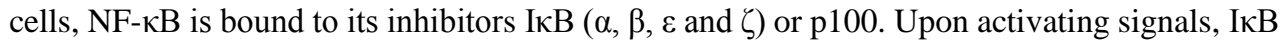
kinases (IKKs) phosphorylates the inhibitors IкB or p100, and thereby targeting them for degradation. The released $\mathrm{NF}-\kappa \mathrm{B}$ heterodimer translocate to the nucleus, where it is transcriptionally active (236). The genes activated by NF- $\kappa \mathrm{B}$ include anti-apoptotic genes (e.g. B-cell lymphoma-extra-large (BCL-xl), Survivin and B-cell CLL/lymphoma-2 (BCL-2)), genes that regulate the cell cycle (e.g. cyclin 1, c-Myc and cyclin-dependent kinase-2 (CDK2)) and genes involved in migration and invasion (e.g. MMP-2, MMP-9, intercellular adhesion molecule-1 (ICAM-1), selectin E and inducible NOS) (237, 238). It was shown in HeLa and human glioma cells that ectopic expression of AEG-1 leads to the degradation of inhibitor $\mathrm{I} \kappa \mathrm{B} \alpha$ and increases the DNA binding of the transcriptional activator p50/p65 complex of NF- $\mathrm{kB}$ leading to the expression of NF- $\mathrm{BB}$ downstream targets involved in cell growth, survival, and invasion. Furthermore, the AEG-1 expression was increased and the protein was phosphorylated by the IKK $\beta$ at Ser298 after treatment with the NF- $\kappa$ B activator TNF- $\alpha$. This resulted in the interaction with the p65 subunit of NF-kB and nuclear translocation $(204,205$, 210). Additionally, it was shown that AEG-1 functions as a bridging factor between NF- $\kappa \mathrm{B}$ and the cAMP response element-binding protein (CREB) to induce interleukin-8 (IL-8) transcription, a promotor of angiogenesis, cell growth and migration $(205,239)$.

The second discovered major pathway activated by AEG-1 is the PI3K/Akt signalling pathway (240). The PI3 kinase constitutes of a regulatory subunit p85 and a catalytic isoform $\mathrm{p} 110$. The auto-phosphorylation of several receptor tyrosine kinases (e.g. EGFR, VEGF, IGFR-1, fibroblast growth factor receptor (FGFR), and Met) attracts the regulatory subunit of PI3K and results in allosteric activation of the catalytic subunit (241). Furthermore, PI3K can be activated directly via G-coupled protein receptors, like Ras (242). The activated kinase generates the second messenger phosphatidylinositol-3,4,5-triphosphate ( $\left.\mathrm{PIP}_{3}\right)$ from phosphatidylinositol4,5-biphosphat $\left(\mathrm{PIP}_{2}\right)$ at the inner site of the cell membrane that leads to the translocation of Akt to the inner membrane and activation via 3-phosphoinositide-dependent protein kinase (PDK) 1 or 2 phosphorylation. Activated Akt translocate to the cytoplasm and nucleus, and activates downstream targets involved in cell survival, cell cycle progression, growth, migration and angiogenesis. The signalling of PI3K to Akt is regulated by PTEN, a tumour suppressor gene that dephosphorylates $\mathrm{PIP}_{3}$ to $\mathrm{PIP}_{2}$ (243). Overexpression of AEG-1 activates $\mathrm{PI} 3 \mathrm{~K} / \mathrm{Akt}$ and c-Myc expression in primary human foetal astrocytes and thereby inhibits serum starvation-induced apoptosis. In this study, the Akt downstream targets BCL2-associated agonist of cell death (Bad) and p21 were down-regulated, while MDM2 was upregulated (240). 
Other studies showed that inhibition of AEG-1 induced apoptosis via down-regulation of the Akt activity and subsequent upregulated forkhead box (FOXO)3a and FOXO1 activity in prostate and breast cancer cells, respectively (244, 245). AEG-1 up-regulation in human umbilical vein endothelial cells resulted in increased VEGF expression and in human glioma cells increased VEGF promotor activity, both via Akt, resulting in increased angiogenesis (246). Furthermore, AEG-1 has been shown to upregulate cyclin D1 and downregulate p27 in an Akt-dependent way in oesophageal cancer (212). However, the exact activation mechanism of Akt by AEG-1 is still unknown.

Other major signalling pathways activated by AEG-1 are the Wnt and the MAPK signalling pathways by either activation of LEF-1 or extracellular regulated MAP kinase (ERK), or downregulation of APC (202). A study in CRC showed a positive correlation between the AEG-1 expression and the nuclear $\beta$-catenin expression. Furthermore, overexpression of AEG- 1 in the SW480 colon cancer cell line increased nuclear $\beta$-catenin accumulation (247). The MAPK signalling pathway links extracellular signals to processes that regulate growth, proliferation, differentiation, migration, and apoptosis. Thereby, a stimulus (e.g. stress, growth factor, or cytokines) activates a G-coupled receptor, which in turn activates a cascade of three kinases (MAPKKK, MAPKK and MAPK) (248). Inhibitors of the MAPK signalling pathways have been shown to abolish the AEG-1 induced invasion and anchorage-independent growth in HCC cells (202). Apart from the activation of multiple signalling pathways, AEG-1 interacts with a variety of proteins and multiple protein complexes including $\mathrm{CBP}, \mathrm{BCCIP} \alpha, \mathrm{NF}-\kappa \mathrm{B}, \mathrm{SND} 1$, PLZF, ribosome biogenesis regulator homolog (Rrs1), $\beta$-catenin, and ubinuclein-1 (UBN-1) and stimulates tumourigenesis (211).

The AEG-1 expression has been correlated with metastasis in several types of tumours and AEG-1 up-regulation increased migration and invasion in a large variety of cancer cells, as well as metastasis formation in vivo. AEG-1 has been shown to modulate the expression of MMP-2 in glioma and osteosarcoma, and MMP-9 in glioma, prostate cancer, and NSCLC. Furthermore, it was shown that AEG-1 up-regulation induces EMT by several mechanisms, such as Wnt/ $\beta$-catenin and p38 MAPK activation (202, 204, 228, 240, 244, 246, 247, 249-252). In addition to all these tumourigenic properties of AEG-1, gene expression profiles of AEG-1 knockdown breast cancer cells and up-regulation HCC revealed deregulation of several genes, including aldehyde dehydrogenase 3 family, member-A1 (ALDH3A1), Met, heat shock protein 90kDa (HSP90), heme oxygenase-1 (HMOX1), dihydropyrimidine dehydrogenase (DPYD), cytochrome P450, family 2 subfamily B polypeptide-6 (CYP2BO), aldo-keto reductase family 1 member-C2 (AKR1C2) and ATP-binding cassette sub-family C member-11 (ABCC11). All of 
these genes are involved in resistance to various chemotherapeutics, such as 5-FU, doxorubicin, paclitaxel, cisplatin and 4-hydroxycyclophosphamide (202, 224). Furthermore, Zhao et al. showed in 2012 that AEG-1 affects survival, DNA DSB repair, and cell cycle distribution after radiation in the cervical cancer cell line $\mathrm{SiHa}(253)$.

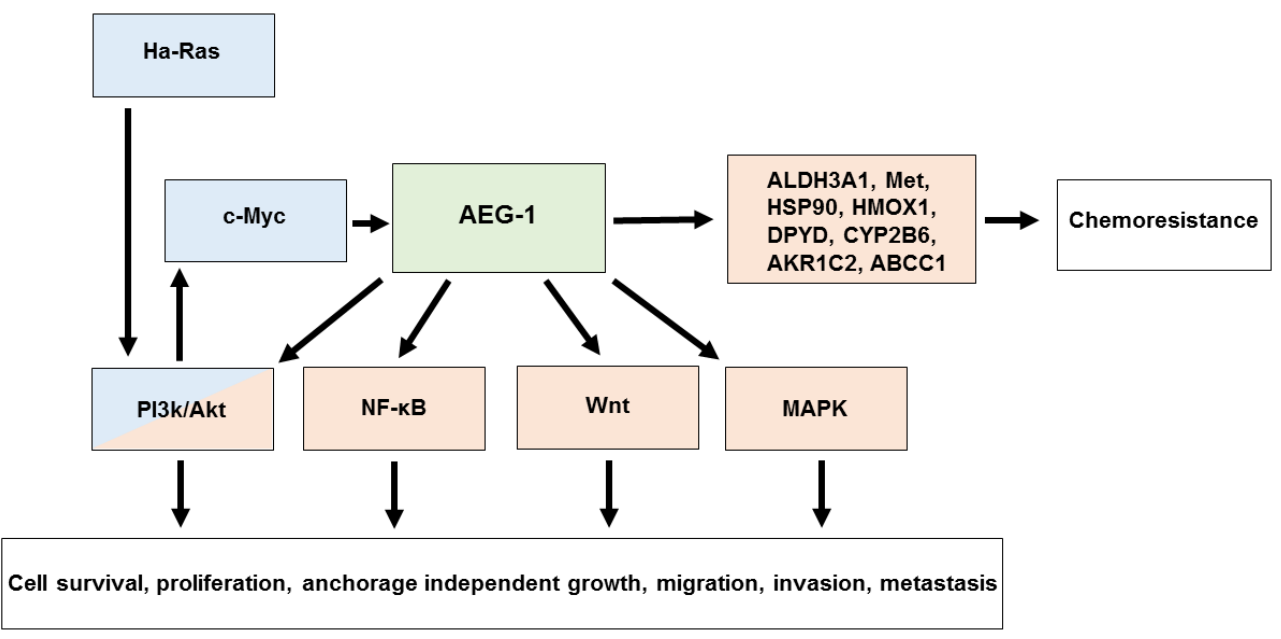

Figure 5. An overview of AEG-1 signalling pathways. AEG-1 has been shown to be activated via Ha-Ras, PI3k/Akt and c-Myc (blue), and contributes through several signalling pathways and proteins (orange) to different aspects of oncogenesis (white). 


\section{$\underline{\text { Aims }}$}

I. To investigate the role of AEG-1 in CRC development

II. To evaluate the impact of AEG-1 on radiation treatment response 


\section{Materials and Methods}

\section{Cancer models and tissue samples}

It is very challenging to select models for cancer research, especially for the complex mechanisms of carcinogenesis and treatment response. The choice for a model depends thereby on the research question, the availability, as well as the knowledge about the application.

\section{Cell lines}

The first successful attempt of studying the behaviour of cells in vitro is attributed to Harrison and his colleagues in 1907, who cultured isolated tadpole tissue in a hanging drop of lymph for up to four weeks (254). Based on these findings, Burrow and Carrel were the first in 1911 to culture and subculture mammalian cells. One of those cell lines explanted from a chicken embryo heart fragment was subcultured over a hundred times and even outlived Carrel by two years (255-257). The implication of tissue culture on cancer research were obvious, and a lot of research was dedicated to be able to study cancer in vitro (258). However, it took almost 40 years until Gey for the first time in 1951 successfully established a human cell line, which was called HeLa (259). The cell line originated from a cervical cancer biopsy specimen of Henrietta Lacks and is currently the most widespread human cell lines (260). Nowadays, cancer cell lines are important tools to study the biology of cancer and for the development of anticancer drugs (261). The cell line models have several advantages, such as the unlimited amount of material, high reproducibility, low cost, and high throughput. However, there are also several limitations with that model and especially the representation and maintenance of the genetic diversity of a tumour are difficult, if not impossible to maintain in a cell culture.

In the studies I-IV we used the KM12C, KM12SM, KM12L4a, SW480, SW620, and HCT116 colon cancer cell lines, as well as the CCD-18Co normal colon fibroblast cell line and the CCD-841CoN normal colon epithelial cell line.

The KM12C cells derived from a patient with stage II colon cancer. The KM12SM cells where "SM" stands for spontaneous metastasis, arose from spontaneous liver metastasis of injected KM12C cells into the caecum of nude mice. The KM12L4a cells were produced by repeated intrasplenic injection of the KM12C cells and harvesting of the liver metastases in nude mice $(262,263)$. "L" stands for liver and " 4 " for four repetitions of intrasplenic injection. The KM12 
cell lines were kindly provided by Dr. Isaiah J. Fidler (M.D. Anderson Cancer Centre, Houston, TX).

The SW480 cell line was established from a primary colon adenocarcinoma, whereas the SW620 derived from a lymph node metastasis, taken from the same patient one year later (264). The HCT116 cell line was one out of three subpopulations of malignant cells isolated from a primary cell culture of human colonic carcinoma (265).

The CCD-18Co fibroblast cell line originated from a colonic mucosal biopsy of a two monthold human infant and was a kind gift of Dr. Richard Palmqvist (Umeå University, Sweden) (266). The CCD-841-CoN epithelial cell line originated from a five month-old human infant and was a kind gift of Dr. Liang Xu (University of Kansas, Lawrence, KS) (267).

The KM12C, KM12SM, KM12L4a, SW480, SW620, CCD-18Co and CCD-841-CoN cell lines were maintained at $37^{\circ} \mathrm{C}$ and $5 \% \mathrm{CO}_{2}$ in Eagle's Minimum Essential Medium (EMEM), supplemented with $10 \%$ heat inactivated foetal bovine serum. For the KM12 cell lines, $2 \%$ vitamin solution and $0.5 \%$ L-glutamine were added, while for the SW480 and SW620 the medium was supplemented with $1 \%$ L-glutamine. The HCT116 cell line was maintained in McCoy's 5A medium supplemented with $10 \%$ heat inactivated foetal bovine serum at $37^{\circ} \mathrm{C}$ and $5 \% \mathrm{CO}_{2}$.

A simple and inexpensive way to study the involvement of a protein in cellular mechanisms is to inhibit or overexpress that protein expression in a cell line. The inhibition of the protein expression, also called gene knockdown can be achieved by several approaches. A common way to knockdown a gene in a eukaryotic cell is based on the findings by Fire and colleagues in Mello's laboratory in 1998 (268). They showed for the first time that the injection of a senseantisense mixture of RNA, covering a segment of a nonessential myofilament protein mRNA (unc-22) in Caenorhabditis elegans, resulted in a highly effective interference with the endogenous gene activity (268). The process behind, called RNAi, can regulate gene expression by inhibiting the translation or by degrading the target mRNA via endonucleases. The basic process can be divided into three steps. Firstly, a long double stranded RNA, which is expressed or introduced into the cells, is processed into a small RNA duplex. Secondly, the duplex is unwound and assembled into the RNA induced silencing complex (RISC) or miRNP and thirdly, the complex binds to the target RNA leading to either RNA cleavage or transcriptional repression (269).

The transfection of a cell with a specific designed double-stranded RNA allows to specifically inhibit the translation of the protein of interest. The cells can be transfected with a transient approach, in which the protein expression is manipulated only for a certain time period, or by 
a stable approach, where the protein expression is continually inhibited. In paper III, we inhibited the AEG-1 protein expression both transient and stable in colon cancer cell lines. For the transient AEG-1 knockdown, we transfected the KM12C, KM12L4a, SW480, SW620, and HCT116 cell line with a pool of four small inhibitory RNAs (siRNA) targeting the AEG-1 mRNA. A scrambled non targeting siRNA was used as a negative control. The knockdown was confirmed by qPCR and Western blot. For the production of stable AEG-1 knockdown cells used in paper III and IV, we transfected the SW480, SW620, and HCT116 cell lines with different DNA plasmids containing two genes for selection (Puromycin resistance and the Green fluorescence protein (GFP) gene), as well as an anti-AEG-1 small (or short) hairpin RNA (shRNA), or a non-targeting shRNA under a viral promoter. After Puromycin selection, single cells expressing GFP were expanded and regularly tested for AEG-1 knockdown by qPCR and Western blot. For AEG-1 up-regulation, the KM12C and KM12L4a cell lines were transiently transfected either with a plasmid containing the AEG-1 cDNA under viral promoter control, or an empty vector as a negative control.

\section{Zebrafish}

Animal models are widely used in cancer research mainly to study carcinogenesis, invasion and metastasis, but also used for treatment development, toxicity and resistance studies. Several animal models, mainly mouse models, have been developed during the years for haematopoietic malignancies and solid tumours (270). However, their relevance to human cancer, especially for treatment development is questionable. A breakthrough in cancer research was in the late 1960s when for the first time a human tumour cell lines was transplanted into immunodeficient mice, a process called xenotransplantation $(271,272)$. The development of mice lacking T, B, and natural killer cells (NSG mice) allowed superior engraftments of healthy and malignant human cells directly from the patient (273). Engraftments of human tumours in mice (either subcutaneously or orthotopic) is considered the golden standard model and has several advantages, especially to examine the therapeutic response to drugs and radiation (274). However, despite the advantages of the model, there are several disadvantages: nude mice husbandry is very expensive and requires specialised facilities, the process from implantation to endpoint measurement can take several months, and it is very difficult to image single cells (275). To overcome those shortcomings various attempts have been made to develop non-mammalian animal models (276-278). A promising model is the Zebrafish (Danio rerio). The Zebrafish model has several advantages compared with the 
classic murine models that include the availability of large number of offspring, the possibility to make the transplantations at embryonic stages, the fish permeability to small molecules, the external development, the availability of transparent lines, the absence of immune rejection in early stages, small number of cells required for transplantation, and a fast readout (279). The first xenotransplantation of human cells into the zebrafish embryo has been reported in 2005 (280). This work has been followed by several studies implanting a diverse range of human cell lines and primary tumours into the zebrafish embryo at different sites. The model has been used to study invasiveness and metastatic behaviour $(278,280)$, angiogenesis $(278,281)$ and response to anticancer therapies $(282,283)$. Despite the advantages and possibilities with the zebrafish model, there are also several limitations such as the lack of knowledge about the niche structures and micro-environmental cues, the disproportional ratio between human cells (large) and zebrafish organs and vessels (small), the different maintenance temperature between the zebrafish and the cell lines $\left(28^{\circ} \mathrm{C} v s 37^{\circ} \mathrm{C}\right)$, different organs, and fewer possibilities for orthotopic transplantation (279).

The transgenic $\operatorname{Tg}\left(\right.$ fli1:EGFP) ${ }^{\mathrm{y} 1}$ zebrafish strain, with enhanced GFP (EGFP) labelled endothelial cells (284), were used and maintained according to standard protocols at the zebrafish facility at Linköping University. Zebrafish were mate overnight in a breeding aquarium, and eggs were collected in the morning immediately after spawning. Subsequently the eggs were cleaned, sorted, and incubated in E3 medium supplemented with 1-phenyl-2thiourea (PTU) at $28.5^{\circ} \mathrm{C}$ in humidified ambient air until injection.

\section{Patients}

A common way to study biomarkers in solid tumours is to analyse tissues taken from the tumour by biopsy or surgery. These samples can either be directly cultured or stored for long time, e.g. frozen or formalin fixed and paraffin-embedded (FFPE), for further analyses. Subsequently DNA, RNA, and proteins can be isolated and analysed in different cells (e.g. tumour and stromal cells), different tissues (normal, adjacent, tumour, and metastasis), and at different sampling time points (e.g. biopsy, surgery, recurrence). Furthermore, the achieved data can be correlated with clinicopathological features, e.g. gender, age, tumour size, stage, differentiation, and survival. However, there are several issues that have to be considered when interpreting the results from patient tumours. The patient population might not be representative, and values such as ethical groups, gender or age might be over- or underrepresented. Confounding factors such as social status, diet, smoking, alcohol consumption, 
and physical activity might be unknown. Furthermore, it can be difficult to identify from which part of the tumour the sample originated (core or border) or to get information about the cellular environment (e.g. close to a blood or lymph vessel). Additionally, tumour cell subpopulations might be under- or over-represented, if not the entire tumour is available.

In paper I and II, we used samples from unselected CRC patients. Tissues were available from the normal mucosa, adjacent mucosa, primary tumour, lymph node metastases, and liver metastases. The samples were collected from the University Hospital Linköping or Vrinnevi Hospital in Norrköping between 1983 and 2004. The samples were either FFPE or snap frozen and stored at $-70^{\circ} \mathrm{C}$ for DNA and RNA extraction. Clinical information about the patient gender and age as well as tumour localisation, stage, and differentiation were collected from the patient records (Table 2). Survival data were obtained from the Swedish National board of Health and Welfare (Socialstyrelsen) and the patients were followed up until the year 2013.

The patient samples analysed in paper III were from the South-East Swedish Health Care region that participated in the randomised Swedish rectal cancer trial of preoperative RT between 1987 and 1990 (156). Patients with stage I-III rectal cancer were randomised for surgery alone (anterior resection or abdominoperineal excision) or preoperative RT followed by surgery. During surgery some of the patients were diagnosed with metastases. These patients have not been included for survival analyses in paper III. The total radiation dose was $25 \mathrm{~Gy}$, given in 5 fractions ( $5 \times 5$ Gy). Surgery was performed after a median of 3 days (range, 0-11 days). Clinical information about the patient's gender and age as well as tumour localisation, stage, differentiation, and recurrence were collected from the patient records (Table 2). Survival data were obtained from the Swedish National board of Health and Welfare (Socialstyrelsen) and the patients were followed up until the year 2004.

The use of all the patient material was approved by the Regional Ethical Review Board in Linköping and an informed consent document was signed by all the participants to the study. 
Table 2: Clinicopathological variables of the patients from paper I-III

\begin{tabular}{|c|c|c|c|c|c|}
\hline \multirow[b]{2}{*}{ Characteristics } & \multicolumn{2}{|c|}{ Paper I } & \multirow[t]{2}{*}{ Paper II } & \multicolumn{2}{|c|}{ Paper III } \\
\hline & $\begin{array}{l}\text { Fresh- } \\
\text { frozen }\end{array}$ & FFPE & & Non-RT & RT \\
\hline Patient number & 156 & 158 & 356 & 78 & 64 \\
\hline Diagnosis (year) & \multicolumn{2}{|c|}{$1983-2003$} & 1989-2004 & \multicolumn{2}{|c|}{$1987-1990$} \\
\hline \multicolumn{6}{|l|}{ Gender } \\
\hline Male & 103 & 88 & 190 & 46 & 40 \\
\hline Female & 53 & 70 & 166 & 32 & 24 \\
\hline Age at diagnosis (years) & $34-94$ & $42-95$ & $35-95$ & $45-80$ & $36-85$ \\
\hline \multicolumn{6}{|l|}{ Tumour location } \\
\hline Colon & 98 & 77 & 203 & - & - \\
\hline Rectum & 57 & 81 & 153 & 78 & 64 \\
\hline \multicolumn{6}{|l|}{ Tumour stage } \\
\hline I & 20 & 25 & 44 & 20 & 16 \\
\hline II & 73 & 61 & 150 & 22 & 25 \\
\hline III & 34 & 40 & 108 & 32 & 17 \\
\hline IV & 18 & 31 & 54 & 4 & 6 \\
\hline \multicolumn{6}{|l|}{ Differentiation } \\
\hline Well & 19 & 9 & 32 & 5 & 4 \\
\hline Moderately & 91 & 98 & 222 & 56 & 40 \\
\hline Poorly & 40 & 50 & 98 & 17 & 20 \\
\hline
\end{tabular}

Varied numbers in the variables are due to missing data 


\section{Methods}

\section{Irradiation of cell lines and zebrafish embryos}

Cell cultures and zebrafish embryos were irradiated with single doses, between 2-10 Gy, with a $6 \mathrm{MV}$ photon spectra using a linear accelerator. The cells and zebrafish embryos were positioned below $3 \mathrm{~cm}$ acryl glass, $105 \mathrm{~cm}$ from the photon source (the distance from the photon source to the acryl glass-surface was $100 \mathrm{~cm}$ ). The dose rate at the position of the cells was $4.8 \mathrm{~Gy} / \mathrm{min}$ and the field size at SSD was 30 x $30 \mathrm{~cm}$ (Figure 6). An unradiated negative control was included in each radiation experiment and treated in the exact same way, apart from radiation.

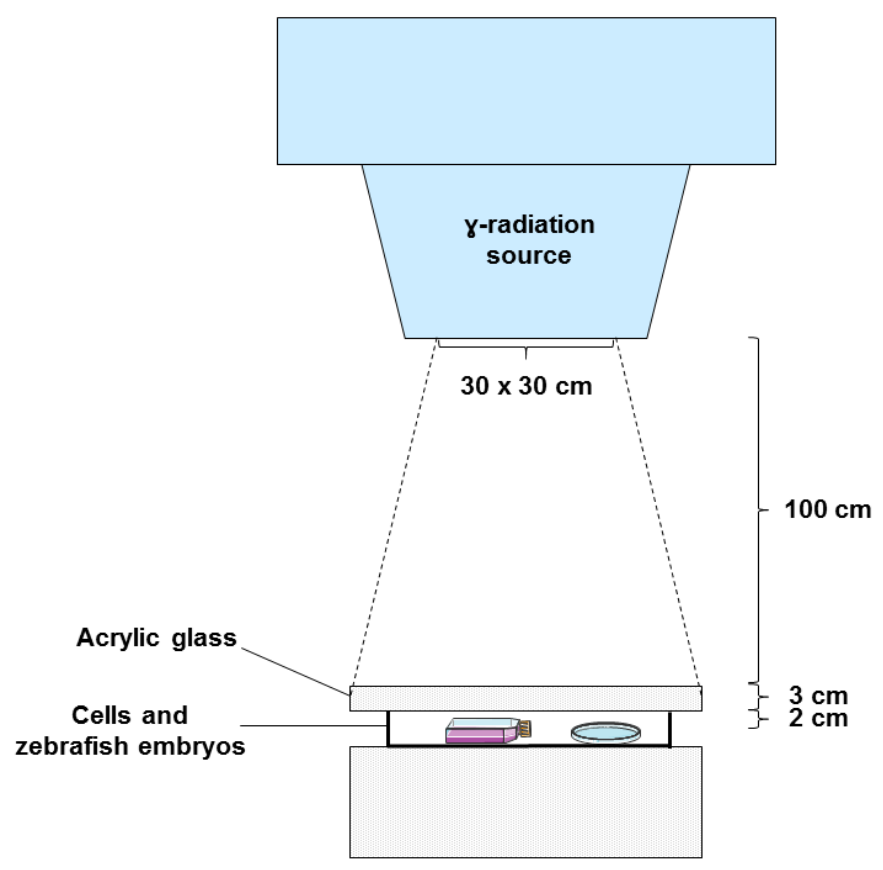

Figure 6. Experimental set-up for cell and zebrafish embryo radiation. 


\section{DNA, RNA and protein extraction}

The careful extraction of DNA and especially RNA and protein is essential for all following molecular analyses. The total DNA and RNA yield should be maximised, while contamination and degradation should be minimised. The successful isolation of nucleic acids requires the effective disruption of cells or tissue, denaturation of nucleoprotein complexes, inactivation of nucleases (DNase and RNase), and low contamination with salts, lipids, proteins and DNA (in RNA samples) or RNA (in DNA samples) (285). Moreover, a high integrity and high concentrations are required for many applications. The correct handling and storage of the samples will increase the stability. This is particularly important for RNA, since it is very susceptible to degradation.

In paper I, we extracted RNA from fresh frozen tissue and colon cancer cell lines using the TRIzol reagent and RNeasy extract Kit according to the manufacturer's instructions. The concentration, purity and integrity of RNA were measured by NanoDrop and Bioanalyzer Agilent, and the samples were stored at $-70^{\circ} \mathrm{C}$.

In paper II we extracted genomic DNA from fresh frozen tissue and colon cancer cell lines using the DNeasy Blood \& Tissue Kit according to the manufacturer's instructions. The DNA concentration and purity was measured by NanoDrop and the integrity by agarose gelelectrophoresis, and the samples were stored at $-70^{\circ} \mathrm{C}$.

The procedure for protein isolation depends on the tissue and cell type, the localisation of the protein (membrane bound, cytoplasmic, nuclear), and the research question. In paper I-IV proteins for Western blot analyses were extracted using analysis buffer containing $150 \mathrm{mM}$ $\mathrm{NaCl}, 2 \%$ Triton, $0.1 \%$ SDS, $50 \mathrm{mM}$ Tris $\mathrm{pH} \mathrm{8.0,} \mathrm{and} \mathrm{10 \%} \mathrm{protease} \mathrm{inhibitor} \mathrm{cocktail.} \mathrm{The}$ lysates were centrifuged to separate the dissolved proteins from the cell fragments and stored at $-20^{\circ} \mathrm{C}$.

\section{Polymerase chain reaction (PCR)}

In many cases, not the entire extracted DNA is of interest, but only particular genes or sequences. The polymerase chain reaction (PCR) is a very powerful and revolutionary technique to amplify a particular sequence out of small amounts of DNA. It was developed in the 1980s by Mullis, who was rewarded for his work on the PCR with the Nobel Prize in Chemistry in 1993 (286). The PCR is based on the amplification of a template DNA and requires four main components: a heat resistant DNA polymerase, deoxynucleotide triphosphates (dNTPS), small oligonucleotides called primers, and the template DNA. The 
PCR consists of three steps. The first step separates the original DNA-double strand into singlestrands using high temperatures (around $90^{\circ} \mathrm{C}$ ), also called melting. In the second step, the sample is cooled and the primer will anneal to the target DNA sequence. The temperature is specific for each primer pair and depends on several physicochemical variables. In the last step, the elongation, the temperature rises up to $72^{\circ} \mathrm{C}$, which is the optimal temperature for the heatresistant DNA polymerase TaqPol that is isolated and named after the thermophile bacterium Thermus aquaticus. The TaqPol takes the primers as a starting point to synthesise a sequencespecific complementary strand to the target DNA using dNTPs (dATP, dGTP, dCTP, dTTP) as building units (287). The copy number doubles with each repetition of these three steps and the final number of copies will be $2^{\mathrm{n}+1}$, while $\mathrm{n}$ is the amount of cycles. The PCR technique has been further developed and several variations have been established.

\section{Capillary Sanger DNA sequencing}

The genome and its sequence have been a main focus in biomedical research over the last decades, especially in cancer research. The completion of the human genome sequencing project in 2003 was a milestone for biomedical research and capillary Sanger sequencing played an essential role (288). Sanger developed the DNA sequencing in the 1970s and was rewarded for this work with his second Nobel Prize in Chemistry in 1980. The method is based on the terminated chain reaction, similar to the PCR described above, but uses radioactively or fluorescently labelled primer and dideoxynucleotide triphosphates (ddNTPs: ddATP, ddGTP, ddCTP, ddTTP) as DNA chain terminators (289). In the beginning of DNA sequencing, the samples were aliquoted into four PCR reactions, each containing one ddNTP and the labelled primer. The random incorporation of the ddNTPs led to the synthesis of DNA fragments with various length. Each of the four reactions where then separated by gel electrophoresis in an individual lane, visualised by autoradiography or UV light, and the sequence was manually read from the gel. In the 1980s, a major development was done by Hood and his colleagues, who fluorescently labelled the ddNTPs. The labelling of each of the four ddNTPs with a fluorescent dye of different emission wavelength allowed to perform the terminated chain reaction with all four ddNTPs in a single reaction (290). The separation by automated capillary gel electrophoresis with on column detection, automated injection, and the multiplexing of this approach increased the capacity of this method significantly $(291,292)$.

In paper II, we analysed the coding region of the $M T D H$ gene by direct Sanger DNA sequencing in $356 \mathrm{CRC}$ tumour samples and three colon cancer cell lines. We therefore pre- 
amplified the sequencing fragments from the isolated DNA by PCR and confirmed the amplification by gel electrophoresis. BigDye Terminator v3.1 Ready Reaction Mix was used for sequencing reaction and separation was performed on ABI 3500 genetic analyser. The collected data were analysed using sequence analyser software. The obtained sequences were compared with a public available reference sequence (NM_178812.3), and mutations were described according to the nomenclature system recommended by the Human Genome Variation Society (HGVS) (293). Designation of the genomic alterations in the MTDH gene is based on the GenBank reference sequences NM_178812. Mutations which were not described in the literature, the Single Nucleotide Polymorphism Database (dbSNP, http://www.ncbi.nlm.nih.gov/SNP/, accessed in June, 2015) (294), or in the Catalogue of Somatic Mutations in Cancer (COSMIC, http://www.sanger.ac.uk/cosmic, accessed in June, 2015) (295), were considered as novel. Exonic variants were evaluated by widely used programs for prediction of possible interference with the function, structure, or stability of the protein: Mutation Taster (http://www.mutationtaster.org; Ensembl transcript ENST00000336273, NM_178812; GRCh37/ Ensembl 69), SIFT and GVGD as a part of commercial Alamut 2.0 (Interactive Biosoftware, Roven, France), PolyPhen-2 (http://genetics.bwh.harvard.edu/pph2/; UniProt peptide Q86UE4), PROVEAN (http://provean.jcvi.org/index.php; Human GRCh37/ Ensemble 66), and MUpro (http://mupro.proteomics.ics.uci.edu).

\section{Quantitative PCR (qPCR) and Reverse transcription PCR}

The quantitative PCR (qPCR), allows to detect and measure the amount of copies produced during each cycle of PCR in real time. Two common methods are applied to detect PCR products. The first method uses a non-specific fluorescence dye like SYBR® green that intercalates with any double-stranded DNA. Increased amplification will lead to an increased fluorescence signal from the dye, allowing to quantify the total amount of double-stranded DNA. However, this method also detects unspecific PCR products (296). The second method is based on the 5'endonuclease activity of the TaqPol and a nonexpendable probe specially designed to hybridise in close proximity to the forward or revers primer, which is labelled with a fluorescent dye as a reporter and a quencher (297). During the annealing phase, both the primer and the probe bind to the template, while the fluorescence signal from the dye is inhibited by the quencher. During the elongation step, the TaqPol synthesises the complementary DNA strand and degrades the probe. The fluorescent reporter dye is released 
from the quencher and its specific emission can be detected. The fluorescence is continuously measured during the PCR and the signal intensity increases proportional to the PCR product. To be able to quantify RNA by qPCR, a complementary DNA (cDNA) strand has to be produced. Reverse transcription PCR uses a retroviral RNA dependent DNA polymerase called reverse transcriptase that produces cDNA from RNA. The reaction consists of dNTPs, RNA, reverse transcriptase and random hexamers or oligo DNA primer, which bind either randomly to the RNA or to the poly a tail of mRNA (298).

In the studies I-IV the High Capacity cDNA Reverse Transcription Kit was used to reverse transcribe RNA using the MultiScribe ${ }^{\mathrm{TM}}$ Reverse Transcriptase according to the manufacturer's instructions. The relative expression levels of AEG-1 mRNA in CRC patient material and colon cancer cell lines were determined by standard curve with TaqMan ${ }^{\mathrm{TM}}{ }^{\circledR}$ Gene Expression Fast Master Mix in Applied Biosystems 7900HT Fast Real-Time PCR system according to the manufacturer's instructions. To adjust for differences in cDNA input, the expression levels where normalised to the housekeeping gene GAPDH.

\section{Immunohistochemistry (IHC)}

Since its discovery in 1941, protein detection in tissue sections via antibody binding is widely used in clinical applications for diagnosis, prognosis, and prediction (299). In principle, a specific antibody binds to an antigen (e.g. protein) and is visualised either directly or indirectly by a fluorophore or a peroxidase-conjugated antibody. A big advantage of immunohistochemistry (IHC) is that protein expression in different parts of the tissue as well as in the subcellular compartments (cytoplasm, nucleus) can be distinguished.

In paper I and III, the FFPE tissue samples were first deparaffinised and the antigen retrieved using the PT-link. Then, the endogenous peroxidases and unspecific binding sites were blocked before the incubation of the tissue sections with the primary antibody. Thereafter, the slides were incubated with a secondary antibody, which was conjugated with horseradish peroxidase (HRP). The HRP-coupled antibodies were visualised using hydrogen peroxide and 3`3'diaminobenzidine tetrachloride and the specimens were counterstained with haematoxylin. The IHC staining was evaluated by two independent observers based on the proportion of positively stained cells, the staining intensity, and localisation, without knowledge of clinicopathological and biological information. 


\section{Western blot}

Western blot is an immunological method developed in the 1970s that allows to identify specific proteins from a complex protein mixture that can be used to compare the expression between different samples (300-302). The technique is divided in three parts: protein separation, transfer to a solid support, and protein visualisation using a specific primary and secondary antibody. In paper I-IV, we used denaturing conditions to separate the proteins according to the size using sodium dodecyl sulphate-polyacrylamide gel electrophoresis (SDSPAGE). The separated proteins were then transferred to a PVDF membrane and unspecific binding sites were blocked. A primary antibody, specific for a certain protein, was subsequently added followed by the incubation with a HRP-conjugated secondary antibody, specific for the primary antibody (303). The protein of interest was then indirectly visualised by the oxidative reaction of luminol catalysed by the HRP and captured by a charged coupled device (CCD) camera. To adjust for differences in total protein loading, the protein levels were normalised to the housekeeping protein $\beta$-actin. Detailed Western blot procedures are described in the respective publications.

\section{Cytokine antibody array}

In paper IV, we used a commercial available human cytokine antibody array. The principle of this array is the same as for Western blot. However, the antibodies specific for the secreted proteins, were covalently linked to a membrane. The membrane was then incubated with the conditioned medium of differently treated cell lines, whereby the secreted proteins attach to the specific antibody on the membrane. Subsequently, the medium was washed away and a secondary biotinylated antibody binds to the attached proteins. In the last step, the membranes were incubated with a HRP-conjugated streptavidin and the visualisation was the same as in the Western blot. A negative control and a positive control were included on each membrane.

\section{Colony forming assay}

The colony forming assay is the golden standard to evaluate cell survival and proliferation in cell culture models upon radiation (304). Single cell suspensions were seeded in 6 well plates, radiated after attachment, and incubated until sufficiently large colonies were formed. After fixation and staining, the colonies were counted and the plating efficiency 
$\left(\mathrm{PE}=\frac{\text { no. of colonies formed }}{\text { no. of cells seeded }} \times 100 \%\right)$ and the surviving fraction $\left(\mathrm{SF}=\frac{\text { no. of colonies formed after treatment }}{\text { no. of cells seeded } \mathrm{XE}}\right)$ were calculated. The SF is used as a measurement to evaluate the effect of radiation on the viability of the different cell lines. It is common to use the SF after 2 Gy radiation to distinguish between radiation resistant $(>50 \%)$ and radiation sensitive cell lines $(<50 \%)$. In paper III, we used the colony forming assay to evaluate the effect of radiation on AEG-1 knockdown and overexpressing colon cancer cell lines. The cells were grown between six and 10 days after radiation and clones of a minimum of 30 and 50 cells, respectively, were counted as one colony.

\section{WST proliferation assay}

The WST proliferation assay is based on the cleavage of the WST-1 tetrazolium salt to formazan by the mitochondrial $\mathrm{NAD}(\mathrm{P}) \mathrm{H}$-dependent oxidoreductases and dehydrogenases, only present in metabolically active cells (305). In paper IV, we used the WST proliferation assay to evaluate whether the reduced radiation-enhanced invasion and migration in the SW480 and HCT116 AEG-1 knockdown cell lines, was due to cell death. Therefore, the cells were seeded $24 \mathrm{~h}$ before radiation with $0 \mathrm{~Gy}$ or $7.5 \mathrm{~Gy}$, and incubated for $24 \mathrm{~h}$. The WST-1 was added and the formation of formazan was quantified by measuring spectrometrically the absorbance at $450 \mathrm{~nm}$.

\section{Boyden chamber assay}

The Boyden chamber assay (or Transwell assay) is a cell migration assay, originally introduced by Boyden to study leukocyte chemotaxis in the 1960s (306). It consists of 2 medium containing chambers that are separated by a porous membrane. Usually, the cells are seeded in the upper chamber in low serum medium and migrate vertical trough the membrane into a lower chamber containing higher serum levels. Cells that have passed the membrane can be fixed, stained, and quantified under a microscope. To be able to study invasion, a modified version of the Boyden chamber can be used, in which the membrane facing the upper chamber is coated with an ECM like matrigel, collagen, or fibronectin before seeding the cells (307). Only cells able to degrade the ECM proteins will be able to migrate through the membrane (Figure 7A). In paper IV, we analysed the impact of AEG-1 and radiation on migration and invasion in several colon cancer cell lines. For the latter experiments we did not apply a serum gradient in order to study only the radiation effect, and radiated the cells with either 0 Gy or 
7.5 Gy. Additionally, we analysed the impact of AEG-1 in the radiation enhanced migration and invasion (Figure 7A).

\section{Zebrafish invasion assay}

In paper IV, we evaluated whether the zebrafish model can be used to study radiation enhanced invasion and whether AEG-1 is involved in this process. We therefore implanted 1,1' dioctadecyl-3,3,3' 3 ' -tetramethylindocarbocyanine (DIL) labelled AEG-1 knockdown, negative control, or non-transfected SW480 cell lines in the perivitelline space of $48 \mathrm{~h}$ old transgenic $\operatorname{Tg}\left(\right.$ fli1:EGFP) ${ }^{\mathrm{y} 1}$ zebrafish embryos (284). After the injection, the sebrafish embryos with labelled cells in the circulation were excluded. The embryos were then radiated with doses between 0-10 Gy and incubated at $28.5^{\circ} \mathrm{C}$ in humidified ambient air. The amount of cells posterior to the anal opening were visualised under a florescence microscope and counted (Figure 7B).

A

In vitro migration

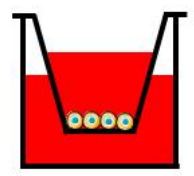

$0,7.5 \mathrm{~Gy}$

In vitro invasion

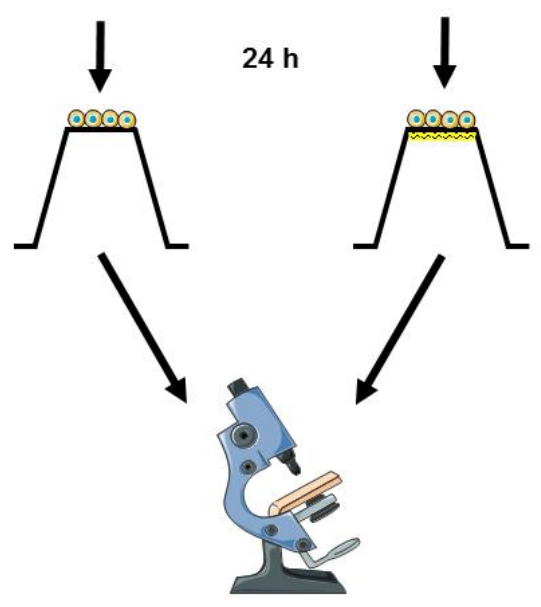

B

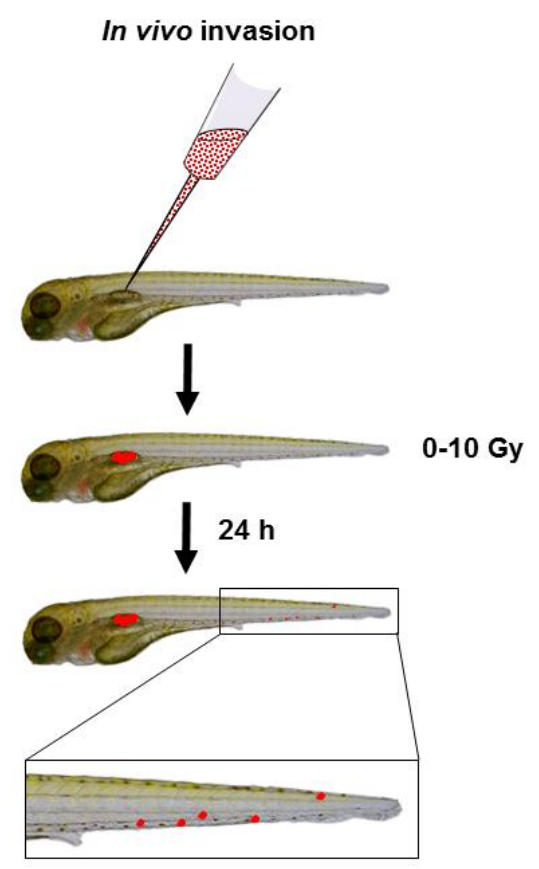

Figure 7. Schematic presentation of A) In vitro migration and invasion assay and B) In vivo zebrafish invasion assay. 


\section{Statistical analyses}

In paper I, we used the Student's $t$-test to analyse the differences in AEG-1 mRNA expression between different tissues. Student's $t$-test or one-way ANOVA method was used to analyse the relationship between the AEG-1 mRNA and clinicopathological variables. In paper III and IV the Student's $t$-test was applied for the in vitro and in vivo studies to test for difference between the treatment groups. In paper I and III, McNemar's or Chi-square test was applied to examine the differences in AEG-1 expression between different tissues analysed by IHC, as well as the association with clinicopathological or biological variables. In paper I, the Cox's Proportional Hazard Model was used to test the relationship between the AEG-1 expression and the patient survival. In paper III, the Log-rank test was used to examine the relationship of the AEG-1 expression with the relative risk for distant recurrence and the patient disease-free survival. In paper III, the Stratified log-rank test was used for examining independency of AEG-1 expression from tumour stage in the relative risk of distant recurrence and disease-free survival (308). Survival curves were computed according to the Kaplan-Meier method.

All cell line experiments were performed at least 3 times and data were presented as the mean \pm standard deviation. All data were analysed by the statistical program STATISTICA (SatSoft, Tulsa, OK) or Excel (Microsoft, Redmond, WA). All tests were 2 tailed, and a p-value less than 0.05 was considered as significant. 


\section{$\underline{\text { Results and Discussion }}$}

\section{Alterations of AEG-1 in relation to $\mathrm{CRC}$ development}

\section{AEG-1 mRNA and protein expression in CRC patients and colon cancer cell lines}

AEG-1 was shown to be up-regulated in several kinds of cancers, including oesophageal squamous cell carcinoma (212), gastric cancer (213), HCC (202), NSCLC (215), neuroblastoma (216), breast cancer (217), prostate cancer (203), and renal cell carcinoma (218), compared with normal cells and the matched non-neoplastic tissue. However, data about the expression of AEG-1 in CRC was largely unknown. Therefore, we analysed the AEG-1 mRNA and protein expression in different tissues from CRC patients and colon cancer cell lines in paper I (309).

The AEG-1 protein localisation and expression was evaluated by IHC in CRC patient samples from the distant normal and adjacent normal mucosa, primary tumour, and metastasis in the regional lymph nodes and liver. We found cytoplasmic and nuclear AEG-1 staining in all tissues analysed, whereby strong nuclear expression was found in more than half of the tumours, and strong cytoplasmic expression in every third tumour. The AEG-1 protein has been detected before at multiple cell localisations, including cell membrane, cytoplasm, endoplasmic reticulum, nucleus, and nucleolus $(200,201,203)$. It was suggested that AEG-1 isoforms, produced by alternative transcription starting sites, splicing and/or posttranslational modifications like ubiquitination, alter the localisation of the AEG-1 protein $(201,203)$. However, other studies analysing the AEG-1 expression in CRC showed no or only slight nuclear expression $(214,247,310,311)$. The differences in AEG-1 localisation between our study and the other studies performed in CRC, might be due to different antibodies and staining protocols used. These antibodies have different epitopes within the protein and might therefore detect different isoforms of the protein. In addition, we speculated that the different staining pattern might be due to the different ethnical background of the analysed patients (European $v s$ Asian). However, a study by Casimiro et al. (312) analysed the AEG-1 protein expression in a Portuguese CRC population and found only a low percentage $(<5 \%)$ of CRC cases with nuclear AEG-1 expression. Further studies are needed in order to clarify whether the different localization of AEG-1 might play a different role in tumorigenesis.

The AEG-1 expression did not differ between the distant normal mucosa and the adjacent mucosa, neither in the cytoplasm nor in the nucleus, and was therefore considered as one group 
for further analyses to increase the sample size. The AEG-1 protein expression in the primary tumour was higher compared with the normal mucosa, in both the cytoplasm and in the nucleus. To evaluate whether the increased AEG-1 protein expression in the tumour is due to increased AEG-1 transcription, we analysed the AEG-1 mRNA expression in 156 primary tumours, and the corresponding normal mucosa from fresh frozen CRC patient samples. The results showed a significant increase of the AEG-1 mRNA expression in the primary tumour compared with the corresponding normal mucosa, in accordance with reports in HCC (202), and CRC (247, 310). AEG-1 up-regulation both at mRNA and protein level in CRC indicates that the oncogenic function of AEG-1 is likely related to transcriptional up-regulation. Furthermore, AEG-1 protein expression was higher both in lymph node metastasis and in liver metastasis, compared with the primary tumour.

In paper III, we examined the AEG-1 protein expression and localisation by IHC in a cohort of rectal cancer patients, who participated in the randomised Swedish rectal cancer trial of preoperative RT. The samples included tissues from the distant and adjacent normal mucosa, primary rectal adenocarcinoma, and lymph node metastasis. Among the 158 patients analysed, 83 underwent surgery alone and 75 received RT followed by surgery. For this study, we used a different anti-AEG-1 antibody as in paper $\mathbf{I}$, the reason for this change will be discussed later. This antibody has been shown by Western blot to detect only two bands at $65 \mathrm{kDa}$ and $75 \mathrm{kDa}$. AEG-1 expression was detected in the cytoplasm in all the sites, but nuclear expression only in some samples from the distant normal mucosa and the adjacent normal mucosa. Similar to the results obtained in paper I, we found in both the non-RT and RT group that the AEG-1 expression in the primary tumour was significantly higher compared with the distant normal mucosa and with the adjacent mucosa. AEG-1 expression in the lymph node metastasis was elevated compared with the primary tumour, although the difference did not reach statistical significance.

In paper III, we also compared the AEG-1 protein expression in five colon cancer cell lines versus a normal colon cell line and a colon fibroblast cell line by Western blot. The AEG-1 expression was higher in three cancer cell lines compared with the normal cell line and the fibroblast cell line, sustaining the up-regulation of AEG-1 in cancer. To further evaluate the impact of the AEG-1 expression on metastasis, we analysed the mRNA and protein expression levels in the SW480 primary colon cancer cell line and its lymph node metastatic counterpart SW620, as well as from the KM12C primary colon cancer cell line and its experimental metastatic counterpart KM12SM and KM12L4a cell lines in paper I. The SW620 cell line had higher AEG-1 mRNA and protein expression compared with the SW480 cell line. On the 
contrary, there was no statistically significant difference in the AEG-1 mRNA and protein expression among the KM12C, KM12SM and KM12L4a cell lines. The bands detected by Western blot were at $65 \mathrm{kDa}$ and $75 \mathrm{kDa}$ in all of the cell lines as well as a band around $35 \mathrm{kDa}$ in the SW480 and KM12C cell lines. The varied bands might be due to alternative transcription starting sites, splicing and/or posttranslational modifications like ubiquitination (201, 203). To our knowledge, no other study analysing AEG-1 in CRC has found a band as low as $35 \mathrm{kDa}$ by Western blot and that might be an explanation for the different staining patterns found by IHC $(214,247,310)$. The higher expression of AEG-1 found in samples from lymph node and liver metastases in both patients and cell lines confirms the importance of AEG-1 in CRC metastasis, and is in line with other studies performed in CRC $(214,247,310)$.

Taken together, the AEG-1 mRNA and protein expression are increased in CRC compared with the normal mucosa, independently of RT, and further elevated in metastatic lesions. These results suggest an important role of AEG-1 in CRC development and metastasis.

\section{MTDH genetic variants in CRC patients and colon cancer cell lines}

As we showed in paper I and III, AEG-1 is involved in CRC development. Several studies have establish AEG-1 as an oncogene, and different mechanisms have been suggested to explain the up-regulation of AEG-1 in cancer (223). Moreover, many oncogenes involved in colorectal carcinogenesis have been shown to have genetic alterations, including point mutations, insertions, deletions, and gene amplification $(9,313,314)$. However, it is unknown whether mutations in the $M T D H$ gene appear during carcinogenesis.

We therefore determined in paper II the frequency and the spectrum of $M T D H$ variants by direct Sanger DNA sequencing of the complete coding sequence of the $M T D H$ gene in 356 tumour samples from CRC patients. We found 50 single nucleotide variants, eight of the variants were exonic and 42 were in a non-coding region adjacent to an exon. No variant was detected in the SW480, SW620 and HCT116 cell lines. Among all the variants, there were four novel exonic variants (c.533delA, c.977C >G, c.1340dupA and c.1731delA) and 25 novel intronic variants adjacent to exons.

The impact of the intronic variants is difficult to evaluate. Introns are non-coding regions between the exons that can have multiple functions. They can contain cis-regulatory elements that control the transcription of nearby genes, splicing regulatory elements and/or non-coding RNA elements, while they can also be without function $(315,316)$. The determination of these elements and the impact of mutations is very challenging. 
Among the eight exonic variants, four were missense (c.160G>A, p.V54M; c.232G>T, p.A78S; c.949A>G, p.T317A, and c.977C>G, p.T326S), one silent (c.1353G>A, p.K451K), and three frame shift mutations (c.533delA, p.N178Tfs34; c.1340dupA, p.K448Efs7, and c.1731delA, p.A578Pfs29). To evaluate whether the exonic variants had an effect on the protein structure or function, six in silico prediction tools were used. The in silico prediction analyses revealed that four of these variants c.232G>T (p.A78S), c.533delA (p.N178Tfs34), c.1340dupA (p.K448Efs7) and c.1731delA (p.A578Pfs29), were deleterious. The variants, c.533delA (p.N178Tfs34), and c.1340dupA (p.K448Efs7), lead to a truncation of the protein, while the variant, c.1731delA (p.A578Pfs29), is predicted to lead to protein prolongation. The frameshift mutations were all heterozygote and only detected each in one patient. Even though the three-dimensional structure of AEG-1 is not completely solved, a transmembrane domain, three putative nuclear localisation signals as well as several protein interaction regions have been identified $(199,203)$. The variant, c.232G $>$ T (p.A78S), found in 35 patients, is located in the extended nuclear localisation region between aa 78 and 130, that has been shown to regulate the nucleolar localization of AEG-1, and in the YY1, BCCIP and PLZF binding region (203, 211). The variant, c.160G>A (p.V54M), even though not predicted to be deleterious, is located in the transmembrane domain, which spans the aa 51 to 72 , as well as in the in the CBP and PLZF binding region (211). Transmembrane domains consist of hydrophobic aa that can interact with the fatty acyl groups of the membrane lipids and anchor the protein to the membrane (8). The variant, c.160G>A (p.V54M), leads to an amino acid substitution from Valine to Methionine, which contain both hydrophobic site chains, thus the effect on the membrane interaction might be at most marginal. However, it would be interesting to analyse, whether the two missense variants have an impact on the protein function and localisation. The exonic variants, c.949A $>$ G, p.T317A and c.977C $>$ G, p.T326S, are not predicted to be deleterious and are not located in any of the described functional regions of the AEG-1 protein. We also analysed the corresponding normal mucosa, whenever available, to be able to identify whether the exonic mutations are hereditary or appeared during carcinogenesis. Only the variant, c.533delA (p.N178Tfs34), was not detected in the corresponding normal mucosa and we therefore considered it as a somatic mutation. The exonic variants, c.160G>A (p.V54M), c.232G >T (p.A78S), c.949A>G (p.T317A), c.977C >G (p.T326S) and c.1353G>A (p.K451K), were also detected in the corresponding normal mucosa and therefore considered to be germline mutations. 
No conclusion could be drawn about impact of $M T D H$ mutations on the AEG-1 mRNA or protein expression because of the low frequency of mutations and the small amount of matching cases.

Taken together, paper II was the first study to analyse $M T D H$ mutations in tumour tissue, and 29 novel $M T D H$ variants were detected. Three frameshift variants in tumour tissue were probably pathogenic, and two variants were detected in functional protein regions. The only variant found exclusively in the tumour was the variant, c.533delA, suggesting that mutations in the $M T D H$ gene are not frequently acquired during colorectal carcinogenesis.

\section{AEG-1 alterations in relation to clinicopathological and biological variables}

The variants, c.232G $>\mathrm{T}$ (p.A78S), c.382-50C $>\mathrm{T}, \mathrm{c} .1048+131 \mathrm{~T}>\mathrm{G}$ and c.1353G $>\mathrm{A}$, were more frequent in patients $<72$ years-old compared with the patients $\geq 72$ years-old. The intronic variant, c.1048+82delA, was only detected in tumours located in the colon but not those located in the rectum. Interesting, in paper I we found a lower AEG-1 mRNA expression in the colon compared with the rectum, but whether the variant c.1048+82delA influences the transcription or mRNA stabilization has to be experimentally validated. The significant difference in $M T D H$ mutational status and mRNA expression between the colon and the rectum supports the idea of different diseases. However, the protein expression of AEG-1 did not differ between the colon and the rectum in paper I, and no other study analysing the AEG-1 protein expression in CRC has found a difference between the two locations (214). No further correlation between MTDH genetic variants and clinicopathological variables were found in paper II in agreement to a study conducted in breast cancer by Liu et al. (220).

In paper I, AEG-1 mRNA and protein expression decreased from stage I to stage III tumours and was increased in stage IV compared with stage III tumours. We speculated that subclones with high AEG-1 expression within the stage III tumours might invaded into the lymph nodes, leaving a higher amount of low-expressing AEG-1 cells in the primary site. Furthermore, we found that the AEG-1 expression was higher in lymph node metastases compared to stage III tumours. However, no difference of the AEG-1 protein expression among the rectal cancer patients with different stages, in both unradiated and radiated treatment groups were observed in paper III. Other studies analysing the AEG-1 expression in CRC found a gradual increase of the expression from stage I-IV tumours, and a higher expression of tumours with metastases in the lymph nodes compared with tumours without metastases $(214,247,310,311)$. 
High AEG-1 protein expression was correlated to a worse patient survival in several cancer types, including CRC (202, 203, 212-218), however, we could not find a correlation between the AEG-1 mRNA or protein expression and the patient survival in paper I. We hypothesized that the differences between the studies might be due to the different antibody, staining protocols and/or grading systems used in our study compared with the other studies conducted on CRC. Therefore we changed the antibody in paper III to a commonly used anti-AEG-1 antibody as described earlier. However, with the changed antibody, we could not find a correlation of the AEG-1 expression with the patient survival in the untreated rectal cancer patients. It remains unclear as to why we could not find a correlation of the AEG-1 protein expression to the patient survival. We used two patient cohorts and two anti-AEG-1 antibodies, though several factors of biological and technical nature can influence the results of IHC, and might be the reason for the discrepancy between our studies and the other studies performed in $\mathrm{CRC}$, such as the study populations, the follow-up processes of the patients, the quality of the samples, the staining protocol and the grading systems.

The patient cohorts analysed in paper I and paper III have been used to evaluate multiple proteins at our laboratory in the past. Analyses between the AEG-1 protein expression and the expression of the multiple biological factors revealed several correlations. In paper I, cytoplasmic AEG-1 protein expression in the primary tumour was positively correlated with the expression of phosphorylated NF- $\mathrm{BB} / \mathrm{p} 65$ at Ser 536, p73, and Rad50, as well as with the apoptotic rate analysed by terminal deoxynucleotidyl transferase dUTP nick end labelling (TUNEL). Nuclear AEG-1 expression was also positively correlated with phosphorylation of $\mathrm{NF}-\kappa \mathrm{B} / \mathrm{p} 65$ at Ser 536, p73, and Rad50, but not to the apoptotic rate. It has been reported that the phosphorylation of NF- $\mathrm{kB} / \mathrm{p} 65$ at Ser 536 is induced by the IKK $\alpha$ and $\beta$, which are activated by TNF- $\alpha$, leading to p65 translocation to the nucleus (317). One of the initial studies on AEG-1 showed already that the expression increases upon TNF- $\alpha$ treatment (198). Later, treatment with TNF- $\alpha$ showed to induces AEG-1 phosphorylation at Ser298 by the kinase IKK $\beta$ (210). Furthermore, TNF- $\alpha$ treatment or AEG-1 up-regulation increased the interaction with the NF- $\mathrm{BB}$ p65 subunit and nuclear translocation $(198,204,205,210)$. We could confirmed the increased AEG-1 expression and translocation to the nucleolus upon TNF- $\alpha$ treatment in the SW480 cell line (unpublished data).

Based on the correlation between AEG-1 and these factors, we speculated in paper I that AEG-1 might be involved in a p53 independent apoptotic pathway, whereby AEG-1 interacts with NF- $\mathrm{kB} / \mathrm{p} 65$ leading to p73 activation and Noxa induction after genotoxic treatment (318). ATM, together with NF-kappa-B essential modulator (NEMO), degrades I $\mathrm{B} \alpha$ and activates 
$\mathrm{NF}-\kappa \mathrm{B}$ in response to DNA-damage, while Rad50, a member of the MRN-complex, is essential for ATM activation $(319,320)$. So far no other study could find a correlation between AEG-1 and p73 or Rad50. Several factors, however, make it unlikely to detect such a complex signalling by IHC in an unselected patient cohort. The suggested apoptotic pathway was believed to be activated by genotoxic treatment in a p53 independent manner. Since around $50 \%$ of all CRC patients have a mutated TP53 gene, the suggested pathway would only be active in half of the patients; unfortunately, we do not have any information about the TP53 status in our sample set (59). Additionally, patients with low stage tumours did not receive neoadjuvant genotoxic treatment and underwent surgery directly. That significantly reduces the number of patients with tumours that fulfil the framework for the suggested pathway. Besides, the time interval from the last day of the treatment until the day of surgery is unknown to us, but based on the clinical practise, it can take several days to weeks. The expression of p73, however, has been shown in cell line studies to increase shortly after genotoxic treatment like radiation, but does not sustain over several days and the protein expression of Rad50 did not alter upon DNA damage in several cell line models (206, 321-323). Furthermore, there was only a small number of matching cases with the data about expression of AEG-1 and p73 and the apoptotic rate. The proposed pathway remains therefore highly speculative and the reason for the correlations found have to be experimentally validated in further studies.

In the sample set of the patients that participated in the randomised Swedish rectal cancer trial of preoperative RT analysed in paper III, different factors have been analysed, but data about phosphorylation of $\mathrm{NF}-\mathrm{kB} / \mathrm{p} 65$ at Ser 536, p73, Rad50, and the apoptotic rate were not available. In this sample set AEG-1 was negatively correlated with the Mac30 expression and positively with the Ki-67 expression in the non-RT group. Furthermore, AEG-1 was positively related to the expression of FXYD domain containing ion transport regulator 3 (FXYD-3) and Lysyl oxidase (Lox), only in tumours treated with RT. High AEG-1 expression was related to Livin expression in both the non-RT and RT groups. None of these factors have been found before to correlate with AEG-1 and the nature for these correlations remains to be experimentally validated.

Taken together, the results from paper I, II, and III, show that MTDH variants, AEG-1 mRNA and/or protein expression in untreated patients did not correlated to the survival. AEG-1 protein expression positively correlated with phosphorylated NF- $\mathrm{BB} / \mathrm{p} 65$ at Ser 536 confirming the interaction of these two proteins as previously reported. 


\section{AEG-1 and RT}

\section{Evaluation of AEG-1 as a radiosensitising target}

AEG-1 has been show to mediate chemorestistance in HCC and breast cancer cells $(202,224)$. However, whether AEG-1 is involved in radiation response has only been validated in the cervical cancer cell line SiHa, where AEG-1 knockdown resulted in a decreased survival, G2/M phase arrest, and apoptosis after radiation (253). In paper III, we down- and up-regulated the AEG-1 expression in five colon cancer cell lines, and measured the survival after radiation by clonogenic assay. The KM12L4a, SW480, and SW620 cell lines, showed the highest survival after radiation and are also often regarded as radioresistant cell lines (324-326). Transient AEG-1 knockdown in those cell lines lowered survival after 2 Gy radiation compared with the negative control cells. In the KM12C cell line, the survival increased in the AEG-1 knockdown cells after 2 Gy radiation compared with the negative control, whereas no change was seen in the HCT116 cell line. Both of these cell lines had a high radiation sensitivity: only $28 \%$ and $33 \%$ of the KM12C and HCT116 cells, respectively, were able to form colonies after 2 Gy radiation. These results were confirmed in stable AEG-1 knockdown cells of SW480, SW620, and HCT116 the cell lines. Interestingly, among the tested cell lines the KM12C and HCT116 cell line had the highest endogenous AEG-1 protein expression. However, AEG-1 upregulation had no effect on the clonogenic survival of the KM12C and KM12L4a cell lines. Although the predictive role of AEG-1 in the rectal cancer patients has to be further investigate, knockdown of AEG-1 can sensitize resistant colon cancer cell lines to radiation.

\section{Potential of AEG-1 as a prognostic marker after RT}

Despite improved treatment protocols and surgical methods, the frequency of local recurrence and distant recurrence in rectal cancer after neoadjuvant and adjuvant treatment is still very high (327). The cytotoxic effect of the current anti-cancer treatments are not specific for the tumour mass and are accompanied by several side effects, which might even lead to the patient's death (328-330). Nowadays, the most challenging task for the oncologists is to diminish the health risks, improve the quality of life, and to eradicate the tumour. Therefore, there is a need for new and more valuable prognostic markers to improve the patient outcome after the primary treatment. We analysed the AEG-1 expression in a patient cohort from the Swedish rectal cancer trial of preoperative RT in paper III (156). As mentioned before, we could not find any correlation between AEG-1 and the patient survival or recurrence in the 
non-RT patients, or a difference in AEG-1 expression between the non-RT and RT patient groups. In the group of patients treated with RT, however, we found that tumours with a high AEG-1 expression had a higher risk of developing recurrence, especially distant recurrence, compared with the tumours with low AEG-1 expression. Furthermore, high AEG-1 expression was related to worse disease-free survival. A similar trend was obtained when we analysed the all-cause mortality and the cancer-specific mortality. Stratified log-rank analyses showed that the statistical significance remained, independent of the tumour stage. However, the group of patients with AEG-1 negative tumours was very small, with only 13 patients in the RT group, and further studies are needed to confirm these findings in a larger patient cohort. In summary, the increased AEG-1 protein expression was independently related to high risk for distant recurrence and worse disease-free survival in rectal cancer patients treated with preoperative RT.

\section{Impact of AEG-1 in radiation-enhanced metastasis}

The impact of AEG-1 on invasion, migration, and metastasis has been shown in several studies for different kinds of cancers, and we found in paper I that the expression of AEG-1 was increased in liver metastases compared with the primary CRC tumours (109, 204, 224, 247). Hence, we speculated that the increased distant recurrence rate after radiation in high AEG-1 expressing tumours found in paper III could be due to the metastasis promoting properties of AEG-1. In paper IV, we therefore analysed the involvement of AEG-1 in migration and invasion in colon cancer cell lines by Boyden chamber assay. Stable AEG-1 knockdown cells had a lower migration compared to the negative control cells in the SW480, SW620, and HCT116 cell lines. Similar to the migration, stable AEG-1 knockdown cells of all three cell lines had a lower invasion compared with negative control cells in all the analysed cell lines. These results confirmed the involvement of AEG-1 in colon cancer cell migration and invasion, as previously observed by Zhang et al. (247). However, the question remains why AEG-1 correlated with distant recurrence, only in the patients treated with RT but not in the untreated patients. In paper III, we analysed the AEG-1 expression by tissue microarray in three sections taken from different localisations of each tumour block. However, a tumour is a heterogeneous mass of different cell populations, and it might be possible that the samples from the nontreatment group underrepresent the tumour heterogeneity and AEG-1 negative graded tumours actually contain positive AEG-1 cells that facilitate metastasis (331). In the RT group, however, radiation acts as a selection pressure in a similar way as described by the Darwinian evolution 
theory, and lowers the tumour heterogeneity (331-333). In this group, the samples from the tissue microarray might be more representative for the entire tumour and negative graded tumours do not have positive colonies. Since we only found a small amount of negative AEG-1 expressing tumours for both groups, this effect might have a big impact on our sample set. A larger sample group might correct for the tumour heterogeneity.

Furthermore, it might be possible that radiation induces metastasis and AEG-1 is essential for this process in rectal cancer. It has been shown earlier that radiation changes the tumour environment and enhances metastasis in vitro, as well as in vivo, by different mechanisms (170).

We therefore evaluated in paper IV whether radiation enhances migration and invasion in colon cancer cells, and whether AEG is involved in radiation-enhanced migration and invasion. Data about radiation-enhanced migration and invasion in colon cancer are rare and inconclusive. It was shown that cellular migration was diminished in the HCT116 cell line in a dose dependent manner in two different studies $(334,335)$. Another study showed that out of three colon cancer cell lines, only the HCT116 cell line had an increased matrigel invasion upon 4 Gy radiation (336). However, we found, a significant increase of migration upon radiation in the SW480, SW620 and HCT116 cell lines. Additionally, we found that the invasion increased upon radiation in the SW480 cell line. To evaluate whether AEG-1 is involvement in radiation-enhanced migration and invasion, we evaluated the migration of the SW480 and HCT116 AEG-1 knockdown and negative control cells upon radiation treatment. The results showed a significant increase of migration in the negative control cells for both SW480 and HCT116 cell lines, similar to the non-transfected cells. Radiation did not increase the migration of the HCT116 AEG-1 knockdown cells, while the migration increased in the SW480 AEG-1 knockdown cells upon radiation, suggesting independent pathways involved in radiation-enhanced migration. Since radiation-enhanced invasion was only seen in the SW480 cell line, we evaluated the impact of AEG-1 knockdown on radiation-enhanced invasion in the SW480 AEG-1 knockdown and negative control cells. The invasion in the AEG-1 knockdown cells was only slightly increased upon radiation without reaching significance, while a significant increase in invasion upon radiation was observed in the negative control cells. This was confirmed in different AEG-1 knockdown clones with the same AEG-1 shRNA and with a different AEG-1 shRNA. To evaluate whether the reduced amount of migrating and invading cells upon radiation was due to reduced cell viability, we performed a WST-1 proliferation assay. No difference in cell viability, $24 \mathrm{~h}$ after radiation, was observed in the AEG-1 knockdown cells compared with the negative control cells for both the SW480 and HCT116 
cell lines. Taken together, these findings support our hypothesis that AEG-1 is involved in radiation-enhanced migration and invasion, and might explain the findings in the patient material from paper III.

\section{The zebrafish as a novel model to study radiation-enhanced invasion}

To further investigate the process of radiation-enhanced invasion, we developed an embryonic zebrafish model in paper IV, for testing the effects of radiation on early stages of tumour cell invasion and dissemination. The dissemination of SW480 cells in the tail of the fish increased in a dose dependent manner, with a significant increase after 10 Gy radiation showing that the zebrafish model is a great supplementation to the already existing models to study early events in radiation-enhanced invasion. Next, we injected the SW480 AEG-1 knockdown and negative control cells into the zebrafish embryo and radiated them with either $0 \mathrm{~Gy}$ or $10 \mathrm{~Gy}$. As for the non-transfected cells we found in the SW480 negative control cells a significant increase in the disseminated cells into the tail upon radiation. However, only a small and non-significant increase was observed upon radiation for the SW480 AEG-1 knockdown cells. The results from the zebrafish embryo model confirm our results in vitro, whereby the invasion can be enhanced by radiation, and AEG-1 knockdown can inhibit this process.

\section{MMP secretion and expression in relation to the AEG-1 expression and radiation}

It has been reported that both MMP-2 and MMP-9 are up-regulated after radiation in HCC and glioblastoma $(185,188)$. Furthermore, it has been shown that AEG-1 knockdown inhibits invasion and decreases the MMP-9 expression in colon cancer cell lines (337). To evaluate whether MMPs are activated via AEG-1 after radiation, we performed a cytokine antibody array including MMPs and MMP inhibitors, growth factors and receptors, and EMT marker to evaluate possible downstream effectors of AEG-1. The results showed that MMP-8, MMP-9, and EGF increased slightly, or did not change upon radiation in the SW480 negative control cell line while they were decreased in the irradiated SW480 AEG-1 knockdown cells. To evaluate whether AEG-1 influences the MMP-9 secretion via the mRNA expression, we analysed the MMP-9 mRNA expression levels after radiation. Indeed, the MMP-9 mRNA levels were decreased in the SW480 AEG-1 knockdown cells compared with the negative control cells in both the unradiated and radiated samples. Radiation slightly increased the MMP-9 expression in the negative control cell line, whereas there was no change in the AEG-1 
knockdown cell line. It was previously shown that radiation activated MMP-9, and binding of AEG-1 on the MMP-9 promotor involves NF- $\mathrm{BB}(188,338)$. Based on our results, we speculate that AEG-1 inhibits the MMP-9 expression and thereby influences the radiation enhanced invasion. However, it remains to be evaluated whether radiation and AEG-1 also influence the activation of MMP-9 in the intercellular space and whether other factors are involved in AEG-1 mediated cell invasion upon radiation. 


\section{Conclusions}

Based on the findings in paper I-IV, the following conclusions can be drawn:

- AEG-1 is upregulated on the mRNA and protein level during CRC development (paper I and paper III)

- Genetic variants of the $M T D H$ gene are probably not of high clinical importance in CRC (paper II)

- The AEG-1 protein expression is a promising marker to discriminate rectal cancer patients treated with preoperative RT regarding the risk of distant relapse (paper III)

- $\mathrm{AEG}-1$ is a promising radiosensitising target in $\mathrm{CRC}$ (paper III)

- AEG-1 knockdown inhibits migration and invasion, as well as radiationenhanced cell migration and invasion in colon cancer, perhaps via MMP-9 down-regulation (paper IV)

- The zebrafish model can be used to study early events in radiation-enhanced invasion (paper IV) 


\section{Future perspectives}

Hundreds of laboratories around the globe participate in the chase for predictive and prognostic biomarkers to improve the management of cancer. A multiplicity of molecules have been identified for treatment prediction and patient prognosis by several approaches. Unfortunately, the number of markers that have been applied for clinical practices is rather small, even though a need for such applications is immense. The main reason for this unbalance is the rigorous analytical and clinical validation of the markers. In our study, many questions remain to be answered about the impact of AEG-1 in CRC development and radiation response.

- We found a different staining pattern of AEG-1 by IHC in the CRC patients compared with other studies. This is probably because of the detection of several AEG-1 isoforms by using different staining protocols and antibodies. It would be interesting to evaluate the exact reason for the different staining pattern and furthermore, the impact of AEG-1 isoforms in tumourigenesis and treatment response.

- Although we showed that exonic $M T D H$ variants are rare in CRC, it would be interesting to further investigate the protein localisation, protein-interaction, and signalling of these variants and whether they might influence the function of AEG-1 in carcinogenesis and/or treatment response.

- We showed that high AEG-1 expression correlates with worse prognosis only in patients treated with RT. Since the number of patients with low AEG-1 expression was very small in both groups, it is necessary to confirm the results in a larger cohort. Moreover, the treatment regime for rectal cancer has changed since the Swedish rectal cancer trial of preoperative RT was conducted. Therefore, analyses of the AEG-1 expression in a more recent clinical trial, for example the Stockholm III trial, would be needed to determine the value of the AEG-1 expression as a prognostic marker for rectal cancer patients.

- AEG-1 has been shown to be involved in radiation-enhanced migration and invasion in vitro and in vivo, and MMP-9 has been found as a possible downstream target. However, it remains to be solved in which signalling cascade AEG-1 is involved upon radiation, leading to increased migration and invasion, and whether AEG-1 knockdown also decreases the MMP-9 activity.

- Several studies have shown that AEG-1 would be a good target for cancer treatment and it has been discussed a long time to develop specific inhibitors for AEG-1. 
However, even though the crystal structure has not been solved, it does not seem that AEG-1 is a classical druggable target. No catalytic unit has been discovered and the classical binding-pocket approach cannot be applied, though it has been suggested that AEG-1 acts as a bridging factor. It might be more likely that a successful attempt to target AEG-1 is to disrupt the protein-protein binding with an interaction partner. Therefore, further structural analyses of protein complexes are needed to design specific inhibitors and inhibit the AEG-1 mediated oncogenesis. 


\section{$\underline{\text { Acknowledgements }}$}

First of all, I would like to express my gratitude to all who made this thesis possible, especially all the patients that participated in the studies, and the financial supported from the Swedish Cancer Foundation, the Swedish Research Council, the Health Research Council in South-East Sweden, the Stiftelsen Onkologiska klinikernas i Linköping and the LiU Cancer network.

In particular I would like to express my thankfulness to:

My supervisor Xiao-Feng Sun, who welcomed me at Linköping University during my exchange year in Skövde and who gave me the great opportunity to stay in Sweden. Without you I would never have continued in cancer research. I want to thank you for sharing your knowledge and long experience, all proofreading and corrections, especially the commas, for the freedom I got from you in my projects, and for your faith in me.

My co-supervisors Hong Zhang, for giving me the opportunity to go to Linköping and your help with all the tumour grading; John Carstensen, for your help with statistics; and Hans Starkhammar, for your support and valuable discussions.

All former and present members of the Sun laboratory. Ivana, Alessandra, Veronika, Bibbi, Yang-Mei, Chao-Jie, Surajit, Na Liu, Zhen-Yu, Mo-Jin, Jie Ping, Yugang Wen, Stéphanie, David, Birgitta, and Annica. It has been a pleasure to work together with all of you, and I am very thankful for your help in the lab, the valuable discussions, and the BBQs and beers we had together. Most importantly, I would like to thank you for your friendship. I wish you all the best for your future!

Annette Molbaek, Åsa Schippert, Vesa Loitto, Florece Sjögren, and Mikael Pihl, for the technical support throughout the years.

Peter, Frida, Emelie, Dimitrios, Dan, and Anna, for your help on Wednesdays during lunchtime, to radiate billions of cells and hundreds of zebrafish embryos for me.

Lasse and Zaheer, thank you very much for your support with the zebrafish experiments. I always felt very welcome in your lab and I really enjoyed working together with you.

Chatarina Malm for helping me with all the administration.

Erik and Cynthia my office mates and friends. Thanks for complaining together with me, sorting my English to British English, for the beer, wine and whisky, and for all the student labs we had together. In the end it was not too bad to share an office with you ;) I wish you all the best for your thesis!

Olle, Charlotta, Agneta, Bibbi, Annelie, Josefine, Gizeh, Elin, Piiha-Lotta, Linda, Tove, Susanna, Ameet, Gabi, and Vivian, for all your help, support, presentations, discussions, and of course the lunch meetings. I have learned a lot about all different kinds of breast cancer and it has been a pleasure to work, travel and discuss with you!

Olof, my friend and running buddy, we really made the $22 \mathrm{~km}$ with $1100 \mathrm{~m}$ altitude. Thanks for keeping up the speed to a good level, and all the Mario cart, Kingdome builder and Small world sessions. 
All people at KEF, for creating a very nice and friendly working environment. I have learned a lot about Swedish strawberries, and I am sure some day there will be a dish washer in the fika room.

My very good friend Johannes. It all started with an 18 hour train trip to Sweden to brush up our English and enjoy the nature for one year. Thank you for all your support, friendship and the countless hours of scientific discussions. You are truly a nugget $(;)$

Susanna, for being a very good friend and for taking care of Johannes. Many thanks for all the reggae dancing and the cool trip to Germany.

Innebandy gang, for still playing with me even though I am a bad looser and a worse winner.

Julian, my genius roommate and friend from Aschebersch. You have always been very inspiring and you are the best companion to watch Lammbock. I hope we can repeat it some day!

Bert (a.k.a. Flori and Schnotzelbotzel), even though I moved $1500 \mathrm{~km}$ north, you have always been The best friend. I am looking forward to continue to travel the world with you and Meli. (@ Meli, thanks for taking care of Bert and his incurable back disease (:))

Ammy, Bertil and Fabian, my Swedish family. Thank you very much for the warm welcome to your family, all the great experiences you shared with me, and all your help and kindness!

Meine Eltern, vielen Dank für eure Unterstützung euren Glauben und euer Mitgefühl! Ihr habt nie an mir gezweifelt und wart immer für mich da.

Tanja meine großartige und schlaue große Schwester. Ohne dich hätte ich wohl nie angefangen zu studieren. Ich wünsche dir alles erdenklich Gute für deine Dissertation und Zukunft. Ich bin sehr froh dass du mit Alex einen super Partner gefunden hast, von dem ich mir sicher bin das er gut auf dich aufpasst und in deiner Liga spielt. Ich freue mich schon sehr auf unser nächstes gemeinsames Weinschen und Weissbeer.

EBBA my sweetie! Thank you very much for being always there for me, your support, and your love. I am looking forward to our future 


\section{$\underline{\text { References }}$}

1. Faguet GB. A brief history of cancer: age-old milestones underlying our current knowledge database. Int J Cancer. 2015;136(9):2022-36.

$2 . \quad$ Stratton MR, Campbell PJ, Futreal PA. The cancer genome. Nature. 2009;458(7239):719-24.

3. Ferlay J, Soerjomataram I, Dikshit R, Eser S, Mathers C, Rebelo M, et al. Cancer incidence and mortality worldwide: Sources, methods and major patterns in GLOBOCAN 2012. Int J Cancer. 2014.

4. Lopez AD, Mathers CD, Ezzati M, Jamison DT, Murray CJ. Global and regional burden of disease and risk factors, 2001: systematic analysis of population health data. Lancet. 2006;367(9524):1747-57.

$5 . \quad$ Vogelstein B, Kinzler KW. The multistep nature of cancer. Trends Genet. 1993;9(4):138-41.

$6 . \quad$ Yates LR, Campbell PJ. Evolution of the cancer genome. Nat Rev Genet. 2012;13(11):795-806.

7. Hanahan D, Weinberg RA. The hallmarks of cancer. Cell. 2000;100(1):57-70.

8. Johnson A, Lewis J, Morgan D, Raff M, Roberts K, Walter P, et al. Molecular biology of the cell. Sixth edition. ed. xxxiv, 1342, 34, 53, 1 pages $p$.

9. Fearon ER, Vogelstein B. A genetic model for colorectal tumorigenesis. Cell. 1990;61(5):759-67.

10. Frank SA. Dynamics of cancer incidence, inheritance, and evolution. Princeton, N.J.:

Princeton University Press,; 2007. Available from:

http://www.ncbi.nlm.nih.gov/books/bv.fcgi?rid=dyncan.TOC.

$11 . \quad H a n a h a n$ D, Weinberg RA. Hallmarks of cancer: the next generation. Cell. 2011;144(5):646-74.

12. Cancer i siffror 2013. The National Board of Health and Welfare and The Swedish Cancer Society; 2013.

13. Li FY, Lai MD. Colorectal cancer, one entity or three. J Zhejiang Univ Sci B. 2009;10(3):219-29.

14. Irving $\mathrm{MH}$, Catchpole B. ABC of colorectal diseases. Anatomy and physiology of the colon, rectum, and anus. BMJ. 1992;304(6834):1106-8.

15. Boron WF, Boulpaep EL, Windhager E. Medical physiology : a cellular and molecular approach. Philadelphia, PA: W.B. Saunders; 2003. xiii, 1319 p. p.

16. Beart RW, Melton LJ, 3rd, Maruta M, Dockerty MB, Frydenberg HB, O'Fallon WM. Trends in right and left-sided colon cancer. Dis Colon Rectum. 1983;26(6):393-8.

17. Bufill JA. Colorectal cancer: evidence for distinct genetic categories based on proximal or distal tumor location. Ann Intern Med. 1990;113(10):779-88.

18. lacopetta B. Are there two sides to colorectal cancer? Int J Cancer. 2002;101(5):403-8. 19. Shamsuddin AM, Phelps PC, Trump BF. Human large intestinal epithelium: light microscopy, histochemistry, and ultrastructure. Hum Pathol. 1982;13(9):790-803.

20. Arai T, Kino I. Morphometrical and cell kinetic studies of normal human colorectal mucosa. Comparison between the proximal and the distal large intestine. Acta Pathol Jpn. 1989;39(11):725-30.

21. Liu LU, Holt PR, Krivosheyev V, Moss SF. Human right and left colon differ in epithelial cell apoptosis and in expression of Bak, a pro-apoptotic Bcl-2 homologue. Gut. 1999;45(1):45-50.

22. Macfarlane GT, Gibson GR, Cummings JH. Comparison of fermentation reactions in different regions of the human colon. J Appl Bacteriol. 1992;72(1):57-64. 
23. McBain AJ, Macfarlane GT. Ecological and physiological studies on large intestinal bacteria in relation to production of hydrolytic and reductive enzymes involved in formation of genotoxic metabolites. J Med Microbiol. 1998;47(5):407-16.

24. Haggar FA, Boushey RP. Colorectal cancer epidemiology: incidence, mortality, survival, and risk factors. Clin Colon Rectal Surg. 2009;22(4):191-7.

25. Watson AJ, Collins PD. Colon cancer: a civilization disorder. Dig Dis. 2011;29(2):222-8.

26. Amersi F, Agustin M, Ko CY. Colorectal cancer: epidemiology, risk factors, and health services. Clin Colon Rectal Surg. 2005;18(3):133-40.

27. Haenszel W, Kurihara M. Studies of Japanese migrants. I. Mortality from cancer and other diseases among Japanese in the United States. J Natl Cancer Inst. 1968;40(1):43-68.

28. Larsson SC, Wolk A. Meat consumption and risk of colorectal cancer: a meta-analysis of prospective studies. Int J Cancer. 2006;119(11):2657-64.

29. Hjartaker A, Aagnes B, Robsahm TE, Langseth H, Bray F, Larsen IK. Subsite-specific dietary risk factors for colorectal cancer: a review of cohort studies. J Oncol. 2013;2013:703854.

30. Thorn M, Bergstrom R, Kressner U, Sparen P, Zack M, Ekbom A. Trends in colorectal cancer incidence in Sweden 1959-93 by gender, localization, time period, and birth cohort. Cancer Causes Control. 1998;9(2):145-52.

31. Grady WM. Genetic testing for high-risk colon cancer patients. Gastroenterology. 2003;124(6):1574-94.

32. Kerber RA, Neklason DW, Samowitz WS, Burt RW. Frequency of familial colon cancer and hereditary nonpolyposis colorectal cancer (Lynch syndrome) in a large population database. Fam Cancer. 2005;4(3):239-44.

33. Johns LE, Houlston RS. A systematic review and meta-analysis of familial colorectal cancer risk. Am J Gastroenterol. 2001;96(10):2992-3003.

34. Daley D, Lewis S, Platzer P, MacMillen M, Willis J, Elston RC, et al. Identification of susceptibility genes for cancer in a genome-wide scan: results from the colon neoplasia sibling study. Am J Hum Genet. 2008;82(3):723-36.

35. Hampel H, Frankel WL, Martin E, Arnold M, Khanduja K, Kuebler P, et al. Feasibility of screening for Lynch syndrome among patients with colorectal cancer. J Clin Oncol. 2008;26(35):5783-8.

36. Arvelo F, Sojo F, Cotte C. Biology of colorectal cancer. Ecancermedicalscience. 2015;9:520.

37. Jasperson KW, Tuohy TM, Neklason DW, Burt RW. Hereditary and familial colon cancer. Gastroenterology. 2010;138(6):2044-58.

38. Vasen HF, Mecklin JP, Khan PM, Lynch HT. The International Collaborative Group on Hereditary Non-Polyposis Colorectal Cancer (ICG-HNPCC). Dis Colon Rectum. 1991;34(5):424-5.

39. Rowley PT. Screening for an inherited susceptibility to colorectal cancer. Genet Test. 2004;8(4):421-30.

40. Lynch HT, Smyrk T, Lynch JF. Overview of natural history, pathology, molecular genetics and management of HNPCC (Lynch Syndrome). Int J Cancer. 1996;69(1):38-43.

41. Reitmair AH, Cai JC, Bjerknes M, Redston M, Cheng H, Pind MT, et al. MSH2 deficiency contributes to accelerated APC-mediated intestinal tumorigenesis. Cancer Res. 1996;56(13):2922-6.

42. Kinzler KW, Vogelstein B. Lessons from hereditary colorectal cancer. Cell. 1996;87(2):159-70.

43. Groden J, Thliveris A, Samowitz W, Carlson M, Gelbert L, Albertsen H, et al. Identification and characterization of the familial adenomatous polyposis coli gene. Cell. 1991;66(3):589-600.

44. Barker N. The canonical Wnt/beta-catenin signalling pathway. Methods Mol Biol. 2008;468:5-15. 
45. Mann B, Gelos M, Siedow A, Hanski ML, Gratchev A, llyas M, et al. Target genes of beta-catenin-T cell-factor/lymphoid-enhancer-factor signaling in human colorectal carcinomas. Proc Natl Acad Sci U S A. 1999;96(4):1603-8.

46. Feinberg AP, Gehrke CW, Kuo KC, Ehrlich M. Reduced genomic 5-methylcytosine content in human colonic neoplasia. Cancer Res. 1988;48(5):1159-61.

47. Goelz SE, Vogelstein B, Hamilton SR, Feinberg AP. Hypomethylation of DNA from benign and malignant human colon neoplasms. Science. 1985;228(4696):187-90.

48. Silverman AL, Park JG, Hamilton SR, Gazdar AF, Luk GD, Baylin SB. Abnormal methylation of the calcitonin gene in human colonic neoplasms. Cancer Res. 1989;49(13):3468-73.

49. Kulis M, Esteller M. DNA methylation and cancer. Adv Genet. 2010;70:27-56.

50. Schubeler D. Function and information content of DNA methylation. Nature. 2015;517(7534):321-6.

51. Song CX, He C. Balance of DNA methylation and demethylation in cancer development. Genome Biol. 2012;13(10):173.

52. Liu XL, Jakubowski M, Hunt JL. KRAS Gene Mutation in Colorectal Cancer Is Correlated With Increased Proliferation and Spontaneous Apoptosis. American Journal of Clinical Pathology. 2011;135(2):245-52.

53. Haigis KM, Kendall KR, Wang Y, Cheung A, Haigis MC, Glickman JN, et al. Differential effects of oncogenic $\mathrm{K}$-Ras and $\mathrm{N}$-Ras on proliferation, differentiation and tumor progression in the colon. Nat Genet. 2008;40(5):600-8.

54. Fearon ER, Cho KR, Nigro JM, Kern SE, Simons JW, Ruppert JM, et al. Identification of a chromosome 18q gene that is altered in colorectal cancers. Science. 1990;247(4938):49-56.

55. Castets M, Broutier L, Molin Y, Brevet M, Chazot G, Gadot N, et al. DCC constrains tumour progression via its dependence receptor activity. Nature. 2012;482(7386):534-7.

56. Takagi Y, Koumura H, Futamura M, Aoki S, Ymaguchi K, Kida H, et al. Somatic alterations of the SMAD-2 gene in human colorectal cancers. Br J Cancer. 1998;78(9):1152-5.

57. $\quad \mathrm{Xu}$ J, Attisano L. Mutations in the tumor suppressors Smad2 and Smad4 inactivate transforming growth factor beta signaling by targeting Smads to the ubiquitin-proteasome pathway. Proc Natl Acad Sci U S A. 2000;97(9):4820-5.

58. Vogelstein B, Lane D, Levine AJ. Surfing the p53 network. Nature. 2000;408(6810):307-10.

59. lacopetta B. TP53 mutation in colorectal cancer. Hum Mutat. 2003;21(3):271-6.

60. Kubbutat MH, Jones SN, Vousden KH. Regulation of p53 stability by Mdm2. Nature. 1997;387(6630):299-303.

61. Banin S, Moyal L, Shieh S, Taya Y, Anderson CW, Chessa L, et al. Enhanced phosphorylation of p53 by ATM in response to DNA damage. Science. 1998;281(5383):1674-7. 62. Sakaguchi K, Herrera JE, Saito S, Miki T, Bustin M, Vassilev A, et al. DNA damage activates p53 through a phosphorylation-acetylation cascade. Genes Dev. 1998;12(18):2831-41.

63. Brooks CL, Gu W. New insights into p53 activation. Cell Res. 2010;20(6):614-21.

64. Levine AJ. p53, the cellular gatekeeper for growth and division. Cell. 1997;88(3):323-

31.

65. Ho WC, Fitzgerald MX, Marmorstein R. Structure of the p53 core domain dimer bound to DNA. J Biol Chem. 2006;281(29):20494-502.

66. Olivier M, Hollstein M, Hainaut P. TP53 mutations in human cancers: origins, consequences, and clinical use. Cold Spring Harb Perspect Biol. 2010;2(1):a001008.

67. Soong R, Robbins PD, Dix BR, Grieu F, Lim B, Knowles S, et al. Concordance between p53 protein overexpression and gene mutation in a large series of common human carcinomas. Hum Pathol. 1996;27(10):1050-5.

68. Boland CR, Goel A. Microsatellite instability in colorectal cancer. Gastroenterology. 2010;138(6):2073-87 e3. 
69.

Moran A, Ortega P, de Juan C, Fernandez-Marcelo T, Frias C, Sanchez-Pernaute A, et al. Differential colorectal carcinogenesis: Molecular basis and clinical relevance. World J Gastrointest Oncol. 2010;2(3):151-8.

70. Ionov Y, Peinado MA, Malkhosyan S, Shibata D, Perucho M. Ubiquitous somatic mutations in simple repeated sequences reveal a new mechanism for colonic carcinogenesis. Nature. 1993;363(6429):558-61.

71. Peinado MA, Malkhosyan S, Velazquez A, Perucho M. Isolation and characterization of allelic losses and gains in colorectal tumors by arbitrarily primed polymerase chain reaction. Proc Natl Acad Sci U S A. 1992;89(21):10065-9.

72. Shibata D, Peinado MA, lonov Y, Malkhosyan S, Perucho M. Genomic instability in repeated sequences is an early somatic event in colorectal tumorigenesis that persists after transformation. Nat Genet. 1994;6(3):273-81.

73. Thibodeau SN, Bren G, Schaid D. Microsatellite instability in cancer of the proximal colon. Science. 1993;260(5109):816-9.

74. Duval A, Hamelin R. Mutations at coding repeat sequences in mismatch repairdeficient human cancers: toward a new concept of target genes for instability. Cancer Res. 2002;62(9):2447-54.

75. Boland CR, Thibodeau SN, Hamilton SR, Sidransky D, Eshleman JR, Burt RW, et al. A National Cancer Institute Workshop on Microsatellite Instability for cancer detection and familial predisposition: development of international criteria for the determination of microsatellite instability in colorectal cancer. Cancer Res. 1998;58(22):5248-57.

76. Seyfried TN, Huysentruyt LC. On the origin of cancer metastasis. Crit Rev Oncog. 2013;18(1-2):43-73.

77. Schluter K, Gassmann P, Enns A, Korb T, Hemping-Bovenkerk A, Holzen J, et al. Organspecific metastatic tumor cell adhesion and extravasation of colon carcinoma cells with different metastatic potential. Am J Pathol. 2006;169(3):1064-73.

78. Kindler HL, Shulman KL. Metastatic colorectal cancer. Curr Treat Options Oncol. 2001;2(6):459-71.

79. Friedl P, Wolf K. Tumour-cell invasion and migration: diversity and escape mechanisms. Nat Rev Cancer. 2003;3(5):362-74.

80. Lillie FR. The Development of the Chick. Henry Holt and Co, New York. 1908.

81. Thiery JP. Epithelial-mesenchymal transitions in tumour progression. Nature Reviews Cancer. 2002;2(6):442-54.

82. Lamouille S, Xu J, Derynck R. Molecular mechanisms of epithelial-mesenchymal transition. Nat Rev Mol Cell Biol. 2014;15(3):178-96.

83. Xu J, Lamouille S, Derynck R. TGF-beta-induced epithelial to mesenchymal transition. Cell Res. 2009;19(2):156-72.

84. Davis FM, Azimi I, Faville RA, Peters AA, Jalink K, Putney JW, Jr., et al. Induction of epithelial-mesenchymal transition (EMT) in breast cancer cells is calcium signal dependent. Oncogene. 2014;33(18):2307-16.

85. Bendas G, Borsig L. Cancer cell adhesion and metastasis: selectins, integrins, and the inhibitory potential of heparins. Int J Cell Biol. 2012;2012:676731.

86. Cavallaro U, Christofori G. Cell adhesion in tumor invasion and metastasis: loss of the glue is not enough. Biochim Biophys Acta. 2001;1552(1):39-45.

87. Martin TA, Mason MD, Jiang WG. Tight junctions in cancer metastasis. Front Biosci (Landmark Ed). 2011;16:898-936.

88. Goodenough DA, Paul DL. Gap Junctions. Cold Spring Harbor Perspectives in Biology. 2009;1(1).

89. Balzer EM, Konstantopoulos K. Intercellular adhesion: mechanisms for growth and metastasis of epithelial cancers. Wiley Interdiscip Rev Syst Biol Med. 2012;4(2):171-81. 
90. Cavallaro U, Christofori G. Cell adhesion and signalling by cadherins and Ig-CAMs in cancer. Nat Rev Cancer. 2004;4(2):118-32.

91. Vleminckx K, Vakaet L, Jr., Mareel M, Fiers W, van Roy F. Genetic manipulation of Ecadherin expression by epithelial tumor cells reveals an invasion suppressor role. Cell. 1991;66(1):107-19.

92. Chidgey M, Dawson C. Desmosomes: a role in cancer? Br J Cancer. 2007;96(12):1783-

7.

93. Paschos KA, Canovas D, Bird NC. The role of cell adhesion molecules in the progression of colorectal cancer and the development of liver metastasis. Cell Signal. 2009;21(5):665-74.

94. Hidalgo M, Eckhardt SG. Development of matrix metalloproteinase inhibitors in cancer therapy. J Natl Cancer Inst. 2001;93(3):178-93.

95. Zucker S, Vacirca J. Role of matrix metalloproteinases (MMPs) in colorectal cancer. Cancer Metastasis Rev. 2004;23(1-2):101-17.

96. Lochter A, Bissell MJ. An odyssey from breast to bone: multi-step control of mammary metastases and osteolysis by matrix metalloproteinases. APMIS. 1999;107(1):128-36.

97. Kugler A, Hemmerlein B, Thelen P, Kallerhoff M, Radzun HJ, Ringert RH. Expression of metalloproteinase 2 and 9 and their inhibitors in renal cell carcinoma. J Urol. 1998;160(5):1914-8.

98. Sutinen M, Kainulainen T, Hurskainen T, Vesterlund E, Alexander JP, Overall CM, et al. Expression of matrix metalloproteinases (MMP-1 and -2) and their inhibitors (TIMP-1, -2 and -3 ) in oral lichen planus, dysplasia, squamous cell carcinoma and lymph node metastasis. $\mathrm{Br} J \mathrm{Cancer}$. 1998;77(12):2239-45.

99. Gonzalez-Avila G, Iturria C, Vadillo F, Teran L, Selman M, Perez-Tamayo R. 72-kD (MMP-2) and 92-kD (MMP-9) type IV collagenase production and activity in different histologic types of lung cancer cells. Pathobiology. 1998;66(1):5-16.

100. Kurogi T, Nabeshima K, Kataoka H, Okada Y, Koono M. Stimulation of gelatinase B and tissue inhibitors of metalloproteinase (TIMP) production in co-culture of human osteosarcoma cells and human fibroblasts: gelatinase B production was stimulated via up-regulation of fibroblast growth factor (FGF) receptor. Int J Cancer. 1996;66(1):82-90.

101. Janowska-Wieczorek A, Marquez LA, Nabholtz JM, Cabuhat ML, Montano J, Chang H, et al. Growth factors and cytokines upregulate gelatinase expression in bone marrow CD34(+) cells and their transmigration through reconstituted basement membrane. Blood. 1999;93(10):3379-90. 102. DiPersio CM, Shao M, Di Costanzo L, Kreidberg JA, Hynes RO. Mouse keratinocytes immortalized with large $T$ antigen acquire alpha3beta1 integrin-dependent secretion of MMP9/gelatinase B. J Cell Sci. 2000;113 ( Pt 16):2909-21.

103. Gomez DE, Alonso DF, Yoshiji H, Thorgeirsson UP. Tissue inhibitors of metalloproteinases: structure, regulation and biological functions. Eur J Cell Biol. 1997;74(2):111-22. 104. Murphy G, Stanton H, Cowell S, Butler G, Knauper V, Atkinson S, et al. Mechanisms for pro matrix metalloproteinase activation. APMIS. 1999;107(1):38-44.

105. McCawley LJ, Matrisian LM. Matrix metalloproteinases: multifunctional contributors to tumor progression. Mol Med Today. 2000;6(4):149-56.

106. Cathcart JM, Cao J. MMP Inhibitors: Past, present and future. Front Biosci (Landmark Ed). 2015;20:1164-78.

107. Valastyan S, Weinberg RA. Tumor metastasis: molecular insights and evolving paradigms. Cell. 2011;147(2):275-92.

108. Guo W, Giancotti FG. Integrin signalling during tumour progression. Nat Rev Mol Cell Biol. 2004;5(10):816-26.

109. Brown DM, Ruoslahti E. Metadherin, a cell surface protein in breast tumors that mediates lung metastasis. Cancer Cell. 2004;5(4):365-74.

110. Fidler IJ. The pathogenesis of cancer metastasis: the 'seed and soil' hypothesis revisited. Nat Rev Cancer. 2003;3(6):453-8. 
111.

Al-Mehdi AB, Tozawa K, Fisher AB, Shientag L, Lee A, Muschel RJ. Intravascular origin of metastasis from the proliferation of endothelium-attached tumor cells: a new model for metastasis. Nat Med. 2000;6(1):100-2.

112. Chambers AF, Groom AC, MacDonald IC. Dissemination and growth of cancer cells in metastatic sites. Nat Rev Cancer. 2002;2(8):563-72.

113. Aguirre-Ghiso JA. Models, mechanisms and clinical evidence for cancer dormancy. Nat Rev Cancer. 2007;7(11):834-46.

114. Kitamura T, Qian BZ, Pollard JW. Immune cell promotion of metastasis. Nat Rev Immunol. 2015;15(2):73-86.

115. Paget S. The distribution of secondary growths in cancer of the breast. 1889. Cancer Metastasis Rev. 1989;8(2):98-101.

116. Erler JT, Bennewith KL, Cox TR, Lang G, Bird D, Koong A, et al. Hypoxia-induced lysyl oxidase is a critical mediator of bone marrow cell recruitment to form the premetastatic niche. Cancer Cell. 2009;15(1):35-44.

117. Parkin DM, Hakulinen T. Cancer registration: principles and methods. Analysis of survival. IARC Sci Publ. 1991(95):159-76.

118. Dukes CE. The Classification of Cancer of the Rectum. Diseases of the Colon \& Rectum. 1980;23(8):605-11.

119. Turnbull RB, Jr., Kyle K, Watson FR, Spratt J. Cancer of the colon: the influence of the no-touch isolation technic on survival rates. Ann Surg. 1967;166(3):420-7.

$120 . \quad H u t t e r$ RV. At last--worldwide agreement on the staging of cancer. Arch Surg. 1987;122(11):1235-9.

121. S.B. Edge SRB, C.C. Compton. AJCC Cancer Staging Manual (7th ed.). Colon and rectum: Springer-Verlag, New York; 2010. p. 143-64.

122. Compton CC, Fielding LP, Burgart LJ, Conley B, Cooper HS, Hamilton SR, et al. Prognostic factors in colorectal cancer. College of American Pathologists Consensus Statement 1999. Arch Pathol Lab Med. 2000;124(7):979-94.

123. Walther A, Johnstone E, Swanton C, Midgley R, Tomlinson I, Kerr D. Genetic prognostic and predictive markers in colorectal cancer. Nat Rev Cancer. 2009;9(7):489-99.

124. Engstrom PF, Arnoletti JP, Benson AB, 3rd, Chen YJ, Choti MA, Cooper HS, et al. NCCN Clinical Practice Guidelines in Oncology: colon cancer. J Natl Compr Canc Netw. 2009;7(8):778-831.

125. George B, Kopetz S. Predictive and prognostic markers in colorectal cancer. Curr Oncol Rep. 2011;13(3):206-15.

126. Karapetis CS, Khambata-Ford S, Jonker DJ, O'Callaghan CJ, Tu D, Tebbutt NC, et al. Kras mutations and benefit from cetuximab in advanced colorectal cancer. N Engl J Med. 2008;359(17):1757-65.

127. Eberhard DA, Johnson BE, Amler LC, Goddard AD, Heldens SL, Herbst RS, et al. Mutations in the epidermal growth factor receptor and in KRAS are predictive and prognostic indicators in patients with non-small-cell lung cancer treated with chemotherapy alone and in combination with erlotinib. J Clin Oncol. 2005;23(25):5900-9.

128. Amado RG, Wolf M, Peeters M, Van Cutsem E, Siena S, Freeman DJ, et al. Wild-type KRAS is required for panitumumab efficacy in patients with metastatic colorectal cancer. J Clin Oncol. 2008;26(10):1626-34.

129. Di Nicolantonio F, Martini M, Molinari F, Sartore-Bianchi A, Arena S, Saletti P, et al. Wild-type BRAF is required for response to panitumumab or cetuximab in metastatic colorectal cancer. J Clin Oncol. 2008;26(35):5705-12.

130. Scaltriti M, Baselga J. The epidermal growth factor receptor pathway: a model for targeted therapy. Clin Cancer Res. 2006;12(18):5268-72.

131. Walther A, Houlston R, Tomlinson I. Association between chromosomal instability and prognosis in colorectal cancer: a meta-analysis. Gut. 2008;57(7):941-50. 
132.

Ribic CM, Sargent DJ, Moore MJ, Thibodeau SN, French AJ, Goldberg RM, et al. Tumor microsatellite-instability status as a predictor of benefit from fluorouracil-based adjuvant chemotherapy for colon cancer. N Engl J Med. 2003;349(3):247-57.

133. McGranahan N, Swanton C. Biological and therapeutic impact of intratumor heterogeneity in cancer evolution. Cancer Cell. 2015;27(1):15-26.

134. Marte B. Tumour heterogeneity. Nature. 2013;501(7467):327.

135. Jackson SE, Chester JD. Personalised cancer medicine. Int J Cancer. 2015;137(2):262-6. 136. Lobo NA, Shimono Y, Qian D, Clarke MF. The biology of cancer stem cells. Annu Rev

Cell Dev Biol. 2007;23:675-99.

137. Chen K, Huang YH, Chen JL. Understanding and targeting cancer stem cells: therapeutic implications and challenges. Acta Pharmacol Sin. 2013;34(6):732-40.

138. Mahteme H, Pahlman L. Good colorectal cancer surgery. Tech Coloproctol. 2005;9(1):1-7.

139. Lynch ML, Brand MI. Preoperative evaluation and oncologic principles of colon cancer surgery. Clin Colon Rectal Surg. 2005;18(3):163-73.

140. Engstrom PF, Arnoletti JP, Benson AB, 3rd, Chen YJ, Choti MA, Cooper HS, et al. NCCN Clinical Practice Guidelines in Oncology: rectal cancer. J Natl Compr Canc Netw. 2009;7(8):838-81.

141. Kline CL, El-Deiry WS. Personalizing colon cancer therapeutics: targeting old and new mechanisms of action. Pharmaceuticals (Basel). 2013;6(8):988-1038.

142. Xu Y, Villalona-Calero MA. Irinotecan: mechanisms of tumor resistance and novel strategies for modulating its activity. Ann Oncol. 2002;13(12):1841-51.

143. Reed AB. The history of radiation use in medicine. J Vasc Surg. 2011;53(1 Suppl):3S-5S. 144. Grubbe EH. X-ray treatment; its introduction to medicine. J Am Inst Homeopath. 1946;39(12):419-22.

145. Lomax ME, Folkes LK, O'Neill P. Biological consequences of radiation-induced DNA damage: relevance to radiotherapy. Clin Oncol (R Coll Radiol). 2013;25(10):578-85.

146. Jackson SP, Bartek J. The DNA-damage response in human biology and disease. Nature. 2009;461(7267):1071-8.

147. Bernier J, Hall EJ, Giaccia A. Radiation oncology: a century of achievements. Nat Rev Cancer. 2004;4(9):737-47.

148. Regaud $C$. The influence of the duration of irradiation on the changes produced in the testicle by radium. Int J Radiat Oncol Biol Phys. 1977;2(5-6):565-7.

149. Augenstein LG. Advances in radiation biology. New York. p. v.

150. Steel GG, McMillan TJ, Peacock JH. The 5Rs of radiobiology. Int J Radiat Biol. 1989;56(6):1045-8.

151. Pawlik TM, Keyomarsi K. Role of cell cycle in mediating sensitivity to radiotherapy. Int J Radiat Oncol Biol Phys. 2004;59(4):928-42.

152. Hahn R. A contribution to radiotherapy. Fortscnr Geb Rontgenstr Nuklearmed. 1904;8:120-1.

153. Schwarz G. Ueber Desensibilisierung gegen rontgen- und radium-strahlen. Münch Med Wochenschr. 1909;24:1-2.

154. Hall EJ, Giaccia AJ. Radiobiology for the radiologist. 7th ed. Philadelphia: Wolters Kluwer Health/Lippincott Williams \& Wilkins; 2012. ix, 546 p. p.

155. Yom SS. Accelerated repopulation as a cause of radiation treatment failure in nonsmall cell lung cancer: review of current data and future clinical strategies. Semin Radiat Oncol. 2015;25(2):93-9.

156. Improved survival with preoperative radiotherapy in resectable rectal cancer. Swedish Rectal Cancer Trial. N Engl J Med. 1997;336(14):980-7.

157. Kapiteijn E, Marijnen CA, Nagtegaal ID, Putter H, Steup WH, Wiggers T, et al. Preoperative radiotherapy combined with total mesorectal excision for resectable rectal cancer. $\mathrm{N}$ Engl J Med. 2001;345(9):638-46. 
158.

Birgisson H, Pahlman L, Gunnarsson U, Glimelius B, Swedish Rectal Cancer Trial G. Adverse effects of preoperative radiation therapy for rectal cancer: long-term follow-up of the Swedish Rectal Cancer Trial. J Clin Oncol. 2005;23(34):8697-705.

159. Sauer R, Becker H, Hohenberger W, Rodel C, Wittekind C, Fietkau R, et al. Preoperative versus postoperative chemoradiotherapy for rectal cancer. N Engl J Med. 2004;351(17):1731-40.

160. Sauer R, Liersch T, Merkel S, Fietkau R, Hohenberger W, Hess C, et al. Preoperative versus postoperative chemoradiotherapy for locally advanced rectal cancer: results of the German CAO/ARO/AIO-94 randomized phase III trial after a median follow-up of 11 years. J Clin Oncol. 2012;30(16):1926-33.

161. Minsky BD. Short-course radiation versus long-course chemoradiation for rectal cancer: making progress. J Clin Oncol. 2012;30(31):3777-8.

162. Ngan SY, Burmeister B, Fisher RJ, Solomon M, Goldstein D, Joseph D, et al. Randomized trial of short-course radiotherapy versus long-course chemoradiation comparing rates of local recurrence in patients with T3 rectal cancer: Trans-Tasman Radiation Oncology Group trial 01.04. J Clin Oncol. 2012;30(31):3827-33.

163. Colorectal Cancer Collaborative G. Adjuvant radiotherapy for rectal cancer: a systematic overview of 8,507 patients from 22 randomised trials. Lancet. 2001;358(9290):1291-304.

164. Rivera S, Villa J, Quero L, Hennequin C. Adjuvant radiotherapy for rectal cancer: recent results, new questions. Clin Res Hepatol Gastroenterol. 2011;35(1):17-22.

165. Marijnen CA, Kapiteijn E, van de Velde CJ, Martijn H, Steup WH, Wiggers T, et al. Acute side effects and complications after short-term preoperative radiotherapy combined with total mesorectal excision in primary rectal cancer: report of a multicenter randomized trial. J Clin Oncol. 2002;20(3):817-25.

166. Huerta S, Gao XH, Saha D. Mechanisms of resistance to ionizing radiation in rectal cancer. Expert Review of Molecular Diagnostics. 2009;9(5):469-80.

167. Knutsen A, Adell G, Sun XF. Survivin expression is an independent prognostic factor in rectal cancer patients with and without preoperative radiotherapy. Int J Radiat Oncol Biol Phys. 2004;60(1):149-55.

168. Waldner MJ, Neurath MF. The molecular therapy of colorectal cancer. Mol Aspects Med. 2010;31(2):171-8.

169. Weng W, Feng J, Qin H, Ma Y. Molecular therapy of colorectal cancer: progress and future directions. Int J Cancer. 2015;136(3):493-502.

170. Ebos JM. Prodding the Beast: Assessing the Impact of Treatment-Induced Metastasis. Cancer Res. 2015.

171. Kaplan HS, Murphy ED. The effect of local roentgen irradiation on the biological behavior of a transplantable mouse carcinoma; increased frequency of pulmonary metastasis. J Natl Cancer Inst. 1949;9(5-6):407-13.

172. Moncharmont C, Levy A, Guy JB, Falk AT, Guilbert M, Trone JC, et al. Radiationenhanced cell migration/invasion process: a review. Crit Rev Oncol Hematol. 2014;92(2):133-42.

173. von Essen CF. Radiation enhancement of metastasis: a review. Clin Exp Metastasis. 1991;9(2):77-104.

174. Dao TL, Yogo H. Enhancement of pulmonary metastases by $\mathrm{x}$-irradiation in rats bearing mammary cancer. Cancer. 1967;20(11):2020-5.

175. Milas L, Peters $\mathrm{L}$. Conditioning of tissues for metastasis formation by radiation and cytotoxic drugs. Symp Fundam Cancer Res. 1983;36:321-36.

176. Tanaka Y. Effect of lung irradiation on the incidence of pulmonary metastases and its mechanism. Acta Radiol Ther Phys Biol. 1976;15(2):142-8.

177. Travis EL, Reinartz G, Chu AM, Down JD, Fowler JF. Effect of cyclophosphamide or xrays on spontaneously occurring metastases from tumors transplanted into the tails of mice. Cancer Res. 1981;41(5):1803-7. 
178. Barcellos-Hoff MH, Lyden D, Wang TC. The evolution of the cancer niche during multistage carcinogenesis. Nat Rev Cancer. 2013;13(7):511-8.

179. Madani I, De Neve W, Mareel M. Does ionizing radiation stimulate cancer invasion and metastasis? Bulletin Du Cancer. 2008;95(3):292-300.

180. Jung JW, Hwang SY, Hwang JS, Oh ES, Park S, Han IO. Ionising radiation induces changes associated with epithelial-mesenchymal transdifferentiation and increased cell motility of A549 lung epithelial cells. Eur J Cancer. 2007;43(7):1214-24.

181. Fujita M, Otsuka Y, Yamada S, Iwakawa M, Imai T. X-ray irradiation and Rho-kinase inhibitor additively induce invasiveness of the cells of the pancreatic cancer line, MIAPaCa-2, which exhibits mesenchymal and amoeboid motility. Cancer Sci. 2011;102(4):792-8.

182. He E, Pan F, Li G, Li J. Fractionated Ionizing Radiation Promotes EpithelialMesenchymal Transition in Human Esophageal Cancer Cells through PTEN Deficiency-Mediated Akt Activation. PLoS One. 2015;10(5):e0126149.

183. Yan S, Wang Y, Yang Q, Li X, Kong X, Zhang N, et al. Low-dose radiation-induced epithelial-mesenchymal transition through NF-kappaB in cervical cancer cells. Int J Oncol. 2013;42(5):1801-6.

184. Cui YH, Suh Y, Lee HJ, Yoo KC, Uddin N, Jeong YJ, et al. Radiation promotes invasiveness of non-small-cell lung cancer cells through granulocyte-colony-stimulating factor. Oncogene. 2015.

185. Wild-Bode C, Weller M, Rimner A, Dichgans J, Wick W. Sublethal irradiation promotes migration and invasiveness of glioma cells: implications for radiotherapy of human glioblastoma. Cancer Res. 2001;61(6):2744-50.

186. Tsutsumi K, Tsuda M, Yazawa N, Nakamura H, Ishihara S, Haga H, et al. Increased motility and invasiveness in tumor cells that survive $10 \mathrm{~Gy}$ irradiation. Cell Struct Funct. 2009;34(2):89-96.

187. Chou CH, Teng CM, Tzen KY, Chang YC, Chen JH, Cheng JC. MMP-9 from sublethally irradiated tumor promotes Lewis lung carcinoma cell invasiveness and pulmonary metastasis. Oncogene. 2012;31(4):458-68.

188. Cheng JC, Chou CH, Kuo ML, Hsieh CY. Radiation-enhanced hepatocellular carcinoma cell invasion with MMP-9 expression through PI3K/Akt/NF-kappaB signal transduction pathway. Oncogene. 2006;25(53):7009-18.

189. Park CM, Park MJ, Kwak HJ, Lee HC, Kim MS, Lee SH, et al. lonizing radiation enhances matrix metalloproteinase-2 secretion and invasion of glioma cells through Src/epidermal growth factor receptor-mediated p38/Akt and phosphatidylinositol 3-kinase/Akt signaling pathways. Cancer Res. 2006;66(17):8511-9.

190. Zhai GG, Malhotra R, Delaney M, Latham D, Nestler U, Zhang M, et al. Radiation enhances the invasive potential of primary glioblastoma cells via activation of the Rho signaling pathway. J Neurooncol. 2006;76(3):227-37.

191. Su WH, Chuang PC, Huang EY, Yang KD. Radiation-induced increase in cell migration and metastatic potential of cervical cancer cells operates via the K-Ras pathway. Am J Pathol. 2012;180(2):862-71.

192. De Bacco F, Luraghi P, Medico E, Reato G, Girolami F, Perera T, et al. Induction of MET by ionizing radiation and its role in radioresistance and invasive growth of cancer. J Natl Cancer Inst. 2011;103(8):645-61.

193. Kaliski A, Maggiorella L, Cengel KA, Mathe D, Rouffiac V, Opolon P, et al. Angiogenesis and tumor growth inhibition by a matrix metalloproteinase inhibitor targeting radiation-induced invasion. Mol Cancer Ther. 2005;4(11):1717-28.

194. Abdollahi A, Griggs DW, Zieher H, Roth A, Lipson KE, Saffrich R, et al. Inhibition of alpha(v)beta3 integrin survival signaling enhances antiangiogenic and antitumor effects of radiotherapy. Clin Cancer Res. 2005;11(17):6270-9. 
195.

Nozue M, Isaka N, Fukao K. Over-expression of vascular endothelial growth factor after preoperative radiation therapy for rectal cancer. Oncol Rep. 2001;8(6):1247-9.

196. Ibuki Y, Goto R. lonizing radiation-induced macrophage activation: augmentation of nitric oxide production and its significance. Cell Mol Biol (Noisy-le-grand). 2004;50 Online Pub:OL617-26.

197. Su ZZ, Kang DC, Chen Y, Pekarskaya O, Chao W, Volsky DJ, et al. Identification and cloning of human astrocyte genes displaying elevated expression after infection with HIV-1 or exposure to HIV-1 envelope glycoprotein by rapid subtraction hybridization, RaSH. Oncogene. 2002;21(22):3592-602.

198. Su ZZ, Chen Y, Kang DC, Chao W, Simm M, Volsky DJ, et al. Customized rapid subtraction hybridization ( $\mathrm{RaSH}$ ) gene microarrays identify overlapping expression changes in human fetal astrocytes resulting from human immunodeficiency virus-1 infection or tumor necrosis factoralpha treatment. Gene. 2003;306:67-78.

199. Britt DE, Yang DF, Yang DQ, Flanagan D, Callanan H, Lim YP, et al. Identification of a novel protein, LYRIC, localized to tight junctions of polarized epithelial cells. Exp Cell Res.

2004;300(1):134-48.

200. Sutherland HG, Lam YW, Briers S, Lamond Al, Bickmore WA. 3D3/lyric: a novel transmembrane protein of the endoplasmic reticulum and nuclear envelope, which is also present in the nucleolus. Exp Cell Res. 2004;294(1):94-105.

201. Kang DC, Su ZZ, Sarkar D, Emdad L, Volsky DJ, Fisher PB. Cloning and characterization of HIV-1-inducible astrocyte elevated gene-1, AEG-1. Gene. 2005;353(1):8-15.

202. Yoo BK, Emdad L, Su ZZ, Villanueva A, Chiang DY, Mukhopadhyay ND, et al. Astrocyte elevated gene-1 regulates hepatocellular carcinoma development and progression. J Clin Invest. 2009;119(3):465-77.

203. Thirkettle HJ, Girling J, Warren AY, Mills IG, Sahadevan K, Leung H, et al. LYRIC/AEG-1 is targeted to different subcellular compartments by ubiquitinylation and intrinsic nuclear localization signals. Clin Cancer Res. 2009;15(9):3003-13.

204. Emdad L, Sarkar D, Su ZZ, Randolph A, Boukerche H, Valerie K, et al. Activation of the nuclear factor kappaB pathway by astrocyte elevated gene-1: implications for tumor progression and metastasis. Cancer Res. 2006;66(3):1509-16.

205. Sarkar D, Park ES, Emdad L, Lee SG, Su ZZ, Fisher PB. Molecular basis of nuclear factorkappaB activation by astrocyte elevated gene-1. Cancer Res. 2008;68(5):1478-84.

206. . !!! INVALID CITATION !!! \{\}.

207. Ash SC, Yang DQ, Britt DE. LYRIC/AEG-1 overexpression modulates BCCIPalpha protein levels in prostate tumor cells. Biochem Biophys Res Commun. 2008;371(2):333-8.

208. Wan L, Lu X, Yuan S, Wei Y, Guo F, Shen M, et al. MTDH-SND1 interaction is crucial for expansion and activity of tumor-initiating cells in diverse oncogene- and carcinogen-induced mammary tumors. Cancer Cell. 2014;26(1):92-105.

209. Lee SG, Kang DC, DeSalle R, Sarkar D, Fisher PB. AEG-1/MTDH/LYRIC, the beginning: initial cloning, structure, expression profile, and regulation of expression. Adv Cancer Res. 2013;120:1-38.

210. Krishnan RK, Nolte H, Sun T, Kaur H, Sreenivasan K, Looso M, et al. Quantitative analysis of the TNF-alpha-induced phosphoproteome reveals AEG-1/MTDH/LYRIC as an IKKbeta substrate. Nat Commun. 2015;6:6658.

211. Emdad L, Das SK, Dasgupta S, Hu B, Sarkar D, Fisher PB. AEG-1/MTDH/LYRIC: signaling pathways, downstream genes, interacting proteins, and regulation of tumor angiogenesis. Adv Cancer Res. 2013;120:75-111.

212. Yu C, Chen K, Zheng H, Guo X, Jia W, Li M, et al. Overexpression of astrocyte elevated gene-1 (AEG-1) is associated with esophageal squamous cell carcinoma (ESCC) progression and pathogenesis. Carcinogenesis. 2009;30(5):894-901. 
213.

Jian-bo X, Hui W, Yu-long H, Chang-hua Z, Long-juan Z, Shi-rong C, et al. Astrocyteelevated gene-1 overexpression is associated with poor prognosis in gastric cancer. Med Oncol. 2011;28(2):455-62.

214. Song H, Li C, Li R, Geng J. Prognostic significance of AEG-1 expression in colorectal carcinoma. Int J Colorectal Dis. 2010;25(10):1201-9.

215. Song L, Li W, Zhang H, Liao W, Dai T, Yu C, et al. Over-expression of AEG-1 significantly associates with tumour aggressiveness and poor prognosis in human non-small cell lung cancer. $\mathrm{J}$ Pathol. 2009;219(3):317-26.

216. Lee SG, Jeon HY, Su ZZ, Richards JE, Vozhilla N, Sarkar D, et al. Astrocyte elevated gene-1 contributes to the pathogenesis of neuroblastoma. Oncogene. 2009;28(26):2476-84.

217. Li J, Zhang N, Song LB, Liao WT, Jiang LL, Gong LY, et al. Astrocyte elevated gene- 1 is a novel prognostic marker for breast cancer progression and overall patient survival. Clin Cancer Res. 2008;14(11):3319-26.

218. Chen W, Ke Z, Shi H, Yang S, Wang L. Overexpression of AEG-1 in renal cell carcinoma and its correlation with tumor nuclear grade and progression. Neoplasma. 2010;57(6):522-9.

219. Haug S, Schnerch D, Halbach S, Mastroianni J, Dumit VI, Follo M, et al. Metadherin exon 11 skipping variant enhances metastatic spread of ovarian cancer. Int J Cancer. 2015;136(10):2328-40.

220. Liu X, Zhang N, Li X, Moran MS, Yuan C, Yan S, et al. Identification of novel variants of metadherin in breast cancer. PLoS One. 2011;6(3):e17582.

221. Yuan C, Li X, Yan S, Yang Q, Liu X, Kong B. The MTDH (-470G>A) polymorphism is associated with ovarian cancer susceptibility. PLoS One. 2012;7(12):e51561.

222. Yoo BK, Emdad L, Lee SG, Su ZZ, Santhekadur P, Chen D, et al. Astrocyte elevated gene-1 (AEG-1): A multifunctional regulator of normal and abnormal physiology. Pharmacol Ther. 2011;130(1):1-8.

223. Sarkar D, Fisher PB. AEG-1/MTDH/LYRIC: clinical significance. Adv Cancer Res. 2013;120:39-74.

224. Hu G, Chong RA, Yang Q, Wei Y, Blanco MA, Li F, et al. MTDH activation by 8q22 genomic gain promotes chemoresistance and metastasis of poor-prognosis breast cancer. Cancer Cell. 2009;15(1):9-20.

225. Agrawal N, Dasaradhi PV, Mohmmed A, Malhotra P, Bhatnagar RK, Mukherjee SK. RNA interference: biology, mechanism, and applications. Microbiol Mol Biol Rev. 2003;67(4):657-85. 226. Hui AB, Bruce JP, Alajez NM, Shi W, Yue S, Perez-Ordonez B, et al. Significance of dysregulated metadherin and microRNA-375 in head and neck cancer. Clin Cancer Res. 2011;17(24):7539-50.

227. Nohata N, Hanazawa T, Kikkawa N, Mutallip M, Sakurai D, Fujimura L, et al. Tumor suppressive microRNA-375 regulates oncogene AEG-1/MTDH in head and neck squamous cell carcinoma (HNSCC). J Hum Genet. 2011;56(8):595-601.

228. Wang B, Shen ZL, Jiang KW, Zhao G, Wang CY, Yan YC, et al. MicroRNA-217 functions as a prognosis predictor and inhibits colorectal cancer cell proliferation and invasion via an AEG-1 dependent mechanism. BMC Cancer. 2015;15:437.

229. Li W, Zhai L, Zhao C, Lv S. miR-153 inhibits epithelial-mesenchymal transition by targeting metadherin in human breast cancer. Breast Cancer Res Treat. 2015.

230. Yang Y, Wu J, Guan H, Cai J, Fang L, Li J, et al. MiR-136 promotes apoptosis of glioma cells by targeting AEG-1 and Bcl-2. FEBS Lett. 2012;586(20):3608-12.

231. Zhang N, Wang X, Huo Q, Sun M, Cai C, Liu Z, et al. MicroRNA-30a suppresses breast tumor growth and metastasis by targeting metadherin. Oncogene. 2014;33(24):3119-28.

232. Zhang B, Liu XX, He JR, Zhou CX, Guo M, He M, et al. Pathologically decreased miR-26a antagonizes apoptosis and facilitates carcinogenesis by targeting MTDH and EZH2 in breast cancer. Carcinogenesis. 2011;32(1):2-9. 
233.

Kochanek DM, Wells DG. CPEB1 regulates the expression of MTDH/AEG-1 and glioblastoma cell migration. Mol Cancer Res. 2013;11(2):149-60.

234. Srivastava J, Siddiq A, Emdad L, Santhekadur PK, Chen D, Gredler R, et al. Astrocyte elevated gene-1 promotes hepatocarcinogenesis: novel insights from a mouse model. Hepatology. 2012;56(5):1782-91.

235. Lee SG, Su ZZ, Emdad L, Sarkar D, Fisher PB. Astrocyte elevated gene-1 (AEG-1) is a target gene of oncogenic Ha-ras requiring phosphatidylinositol 3-kinase and c-Myc. Proc Natl Acad Sci U S A. 2006;103(46):17390-5.

236. Oeckinghaus A, Hayden MS, Ghosh S. Crosstalk in NF-kappaB signaling pathways. Nat Immunol. 2011;12(8):695-708.

237. Pahl HL. Activators and target genes of Rel/NF-kappaB transcription factors.

Oncogene. 1999;18(49):6853-66.

238. Ling J, Kumar R. Crosstalk between NFkB and glucocorticoid signaling: a potential target of breast cancer therapy. Cancer Lett. 2012;322(2):119-26.

239. Waugh DJ, Wilson C. The interleukin-8 pathway in cancer. Clin Cancer Res. 2008;14(21):6735-41.

240. Lee SG, Su ZZ, Emdad L, Sarkar D, Franke TF, Fisher PB. Astrocyte elevated gene-1 activates cell survival pathways through PI3K-Akt signaling. Oncogene. 2008;27(8):1114-21.

241. Beck JT, Ismail A, Tolomeo C. Targeting the phosphatidylinositol 3-kinase (PI3K)/AKT/mammalian target of rapamycin (mTOR) pathway: an emerging treatment strategy for squamous cell lung carcinoma. Cancer Treat Rev. 2014;40(8):980-9.

242. Fruman DA, Rommel C. PI3K and cancer: lessons, challenges and opportunities. Nat Rev Drug Discov. 2014;13(2):140-56.

243. Fresno Vara JA, Casado E, de Castro J, Cejas P, Belda-Iniesta C, Gonzalez-Baron M. PI3K/Akt signalling pathway and cancer. Cancer Treat Rev. 2004;30(2):193-204.

244. Kikuno N, Shiina H, Urakami S, Kawamoto K, Hirata H, Tanaka Y, et al. Knockdown of astrocyte-elevated gene-1 inhibits prostate cancer progression through upregulation of FOXO3a activity. Oncogene. 2007;26(55):7647-55.

245. Li J, Yang L, Song L, Xiong H, Wang L, Yan X, et al. Astrocyte elevated gene-1 is a proliferation promoter in breast cancer via suppressing transcriptional factor FOXO1. Oncogene. 2009;28(36):3188-96.

246. Emdad L, Lee SG, Su ZZ, Jeon HY, Boukerche H, Sarkar D, et al. Astrocyte elevated gene-1 (AEG-1) functions as an oncogene and regulates angiogenesis. Proc Natl Acad Sci U S A. 2009;106(50):21300-5.

247. Zhang F, Yang Q, Meng F, Shi H, Li H, Liang Y, et al. Astrocyte elevated gene-1 interacts with beta-catenin and increases migration and invasion of colorectal carcinoma. Mol Carcinog. 2013;52(8):603-10.

248. Dhillon AS, Hagan S, Rath O, Kolch W. MAP kinase signalling pathways in cancer. Oncogene. 2007;26(22):3279-90.

249. Liu X, Wang D, Liu H, Feng Y, Zhu T, Zhang L, et al. Knockdown of astrocyte elevated gene-1 (AEG-1) in cervical cancer cells decreases their invasiveness, epithelial to mesenchymal transition, and chemoresistance. Cell Cycle. 2014;13(11):1702-7.

250. Wang F, Ke ZF, Wang R, Wang YF, Huang LL, Wang LT. Astrocyte elevated gene-1 (AEG-1) promotes osteosarcoma cell invasion through the JNK/c-Jun/MMP-2 pathway. Biochem Biophys Res Commun. 2014;452(4):933-9.

251. Wang F, Ke ZF, Sun SJ, Chen WF, Yang SC, Li SH, et al. Oncogenic roles of astrocyte elevated gene-1 (AEG-1) in osteosarcoma progression and prognosis. Cancer Biol Ther. 2011;12(6):539-48.

252. Sun S, Ke Z, Wang F, Li S, Chen W, Han A, et al. Overexpression of astrocyte-elevated gene-1 is closely correlated with poor prognosis in human non-small cell lung cancer and mediates 
its metastasis through up-regulation of matrix metalloproteinase-9 expression. Hum Pathol. 2012;43(7):1051-60.

253. Zhao Y, Moran MS, Yang Q, Liu Q, Yuan C, Hong S, et al. Metadherin regulates radioresistance in cervical cancer cells. Oncol Rep. 2012;27(5):1520-6.

254. Harrison RG, Greenman MJ, Mall FP, Jackson CM. Observations of the living developing nerve fiber. The Anatomical Record. 1907;1(5):116-28.

255. Carrel A, Burrows MT. Cultivation of Tissues in Vitro and Its Technique. J Exp Med. 1911;13(3):387-96.

256. Carrel A, Burrows MT. An Addition to the Technique of the Cultivation of Tissues in Vitro. J Exp Med. 1911;14(3):244-7.

257. Witkowski JA. Alexis Carrel and the mysticism of tissue culture. Med Hist. 1979;23(3):279-96.

258. Paul J. The cancer cell in vitro: a review. Cancer Res. 1962;22:431-40.

259. Gey GO. Some aspects of the constitution and behavior of normal and malignant cells maintained in continuous culture. Harvey Lect. 1954;50:154-229.

260. Lucey BP, Nelson-Rees WA, Hutchins GM. Henrietta Lacks, HeLa cells, and cell culture contamination. Arch Pathol Lab Med. 2009;133(9):1463-7.

261. Wilding JL, Bodmer WF. Cancer cell lines for drug discovery and development. Cancer Res. 2014;74(9):2377-84.

262. Morikawa K, Walker SM, Nakajima M, Pathak S, Jessup JM, Fidler IJ. Influence of organ environment on the growth, selection, and metastasis of human colon carcinoma cells in nude mice. Cancer Res. 1988;48(23):6863-71.

263. Morikawa K, Walker SM, Jessup JM, Fidler IJ. In vivo selection of highly metastatic cells from surgical specimens of different primary human colon carcinomas implanted into nude mice. Cancer Res. 1988;48(7):1943-8.

264. Leibovitz A, Stinson JC, McCombs WB, 3rd, McCoy CE, Mazur KC, Mabry ND. Classification of human colorectal adenocarcinoma cell lines. Cancer Res. 1976;36(12):4562-9. 265. Brattain MG, Fine WD, Khaled FM, Thompson J, Brattain DE. Heterogeneity of malignant cells from a human colonic carcinoma. Cancer Res. 1981;41(5):1751-6.

266. Valentich JD, Popov V, Saada JI, Powell DW. Phenotypic characterization of an intestinal subepithelial myofibroblast cell line. Am J Physiol. 1997;272(5 Pt 1):C1513-24.

267. Sugarman BJ, Aggarwal BB, Hass PE, Figari IS, Palladino MA, Jr., Shepard HM. Recombinant human tumor necrosis factor-alpha: effects on proliferation of normal and transformed cells in vitro. Science. 1985;230(4728):943-5.

268. Fire A, Xu S, Montgomery MK, Kostas SA, Driver SE, Mello CC. Potent and specific genetic interference by double-stranded RNA in Caenorhabditis elegans. Nature. 1998;391(6669):806-11.

269. Meister G, Tuschl T. Mechanisms of gene silencing by double-stranded RNA. Nature. 2004;431(7006):343-9.

270. Teicher BA, SpringerLink (Online service). Tumor Models in Cancer Research. Totowa, NJ: Springer Science+Business Media, LLC,; 2011. Available from: http://dx.doi.org/10.1007/978-160761-968-0.

$271 . \quad$ Rygaard J, Povlsen CO. Heterotransplantation of a human malignant tumour to "Nude" mice. Acta Pathol Microbiol Scand. 1969;77(4):758-60.

272. Giovanella BC, Yim SO, Stehlin JS, Williams LJ, Jr. Development of invasive tumors in the "nude" mouse after injection of cultured human melanoma cells. J Natl Cancer Inst.

1972;48(5):1531-3.

273. Shultz LD, Lyons BL, Burzenski LM, Gott B, Chen X, Chaleff S, et al. Human lymphoid and myeloid cell development in NOD/LtSz-scid IL2R gamma null mice engrafted with mobilized human hemopoietic stem cells. J Immunol. 2005;174(10):6477-89. 
274. Richmond A, Su Y. Mouse xenograft models vs GEM models for human cancer therapeutics. Dis Model Mech. 2008;1(2-3):78-82.

275. Morton CL, Houghton PJ. Establishment of human tumor xenografts in immunodeficient mice. Nat Protoc. 2007;2(2):247-50.

276. Jaklevic B, Uyetake L, Lemstra W, Chang J, Leary W, Edwards A, et al. Contribution of growth and cell cycle checkpoints to radiation survival in Drosophila. Genetics. 2006;174(4):1963-72.

277. Siddiqui SS, Loganathan S, Krishnaswamy S, Faoro L, Jagadeeswaran R, Salgia R. Celegans as a model organism for in vivo screening in cancer: effects of human c-Met in lung cancer affect C-elegans vulva phenotypes. Cancer Biology \& Therapy. 2008;7(6):856-63.

278. Rouhi P, Jensen LD, Cao Z, Hosaka K, Lanne T, Wahlberg E, et al. Hypoxia-induced metastasis model in embryonic zebrafish. Nat Protoc. 2010;5(12):1911-8.

279. Konantz M, Balci TB, Hartwig UF, Dellaire G, Andre MC, Berman JN, et al. Zebrafish xenografts as a tool for in vivo studies on human cancer. Hematopoietic Stem Cells Viii.

2012;1266:124-37.

280. Lee LM, Seftor EA, Bonde G, Cornell RA, Hendrix MJ. The fate of human malignant melanoma cells transplanted into zebrafish embryos: assessment of migration and cell division in the absence of tumor formation. Dev Dyn. 2005;233(4):1560-70.

281. Haldi M, Ton C, Seng WL, McGrath P. Human melanoma cells transplanted into zebrafish proliferate, migrate, produce melanin, form masses and stimulate angiogenesis in zebrafish. Angiogenesis. 2006;9(3):139-51.

282. Geiger GA, Fu W, Kao GD. Temozolomide-mediated radiosensitization of human glioma cells in a zebrafish embryonic system. Cancer Res. 2008;68(9):3396-404.

283. Pruvot B, Jacquel A, Droin N, Auberger P, Bouscary D, Tamburini J, et al. Leukemic cell xenograft in zebrafish embryo for investigating drug efficacy. Haematologica. 2011;96(4):612-6.

284. Jensen LD, Cao Z, Nakamura M, Yang Y, Brautigam L, Andersson P, et al. Opposing effects of circadian clock genes bmal1 and period 2 in regulation of VEGF-dependent angiogenesis in developing zebrafish. Cell Rep. 2012;2(2):231-41.

285. Tan SC, Yiap BC. DNA, RNA, and protein extraction: the past and the present. J Biomed Biotechnol. 2009;2009:574398.

286. Mullis K, Faloona F, Scharf S, Saiki R, Horn G, Erlich H. Specific enzymatic amplification of DNA in vitro: the polymerase chain reaction. Cold Spring Harb Symp Quant Biol. 1986;51 Pt 1:26373.

287. Ishmael FT, Stellato C. Principles and applications of polymerase chain reaction: basic science for the practicing physician. Ann Allergy Asthma Immunol. 2008;101(4):437-43.

288. Venter JC, Adams MD, Myers EW, Li PW, Mural RJ, Sutton GG, et al. The sequence of the human genome. Science. 2001;291(5507):1304-51.

289. Sanger F. The Croonian Lecture, 1975. Nucleotide sequences in DNA. Proc R Soc Lond B Biol Sci. 1975;191(1104):317-33.

290. Smith LM, Sanders JZ, Kaiser RJ, Hughes P, Dodd C, Connell CR, et al. Fluorescence detection in automated DNA sequence analysis. Nature. 1986;321(6071):674-9.

$291 . \quad J o r g e n s o n$ JW, Lukacs KD. Capillary zone electrophoresis. Science. 1983;222(4621):266-72.

292. Kasper TJ, Melera M, Gozel P, Brownlee RG. Separation and detection of DNA by capillary electrophoresis. J Chromatogr. 1988;458:303-12.

293. den Dunnen JT, Antonarakis SE. Mutation nomenclature extensions and suggestions to describe complex mutations: a discussion. Hum Mutat. 2000;15(1):7-12.

294. Coordinators NR. Database resources of the National Center for Biotechnology Information. Nucleic Acids Res. 2013;41(Database issue):D8-D20.

295. Forbes SA, Bindal N, Bamford S, Cole C, Kok CY, Beare D, et al. COSMIC: mining complete cancer genomes in the Catalogue of Somatic Mutations in Cancer. Nucleic Acids Res. 2011;39(Database issue):D945-50. 
296. Wittwer CT, Herrmann MG, Moss AA, Rasmussen RP. Continuous fluorescence monitoring of rapid cycle DNA amplification. Biotechniques. 1997;22(1):130-1, 4-8.

297. Heid CA, Stevens J, Livak KJ, Williams PM. Real time quantitative PCR. Genome Res. 1996;6(10):986-94.

298. Buell GN, Wickens MP, Payvar F, Schimke RT. Synthesis of full length cDNAs from four partially purified oviduct mRNAs. J Biol Chem. 1978;253(7):2471-82.

299. Coons AH. Fluorescent antibodies as histochemical tools. Fed Proc. 1951;10(2):558-9.

300. Towbin H, Staehelin T, Gordon J. Electrophoretic transfer of proteins from

polyacrylamide gels to nitrocellulose sheets: procedure and some applications. Proc Natl Acad Sci U S A. 1979;76(9):4350-4.

301. Renart J, Reiser J, Stark GR. Transfer of proteins from gels to diazobenzyloxymethylpaper and detection with antisera: a method for studying antibody specificity and antigen structure. Proc Natl Acad Sci U S A. 1979;76(7):3116-20.

$302 . \quad$ Burnette WN. "Western blotting": electrophoretic transfer of proteins from sodium dodecyl sulfate--polyacrylamide gels to unmodified nitrocellulose and radiographic detection with antibody and radioiodinated protein A. Anal Biochem. 1981;112(2):195-203.

303. Liu ZQ, Mahmood T, Yang PC. Western blot: technique, theory and trouble shooting. $\mathrm{N}$ Am J Med Sci. 2014;6(3):160.

304. Franken NA, Rodermond HM, Stap J, Haveman J, van Bree C. Clonogenic assay of cells in vitro. Nat Protoc. 2006;1(5):2315-9.

305. Berridge MV, Herst PM, Tan AS. Tetrazolium dyes as tools in cell biology: new insights into their cellular reduction. Biotechnol Annu Rev. 2005;11:127-52.

306. Boyden S. The chemotactic effect of mixtures of antibody and antigen on polymorphonuclear leucocytes. J Exp Med. 1962;115:453-66.

307. Albini A, Iwamoto Y, Kleinman HK, Martin GR, Aaronson SA, Kozlowski JM, et al. A rapid in vitro assay for quantitating the invasive potential of tumor cells. Cancer Res. 1987;47(12):3239-45.

308. Collett D. Modelling survival data in medical research. 2nd ed. Boca Raton, Fla.: Chapman \& Hall/CRC; 2003. 391 p. p.

309. Gnosa S, Shen YM, Wang CJ, Zhang H, Stratmann J, Arbman G, et al. Expression of AEG-1 mRNA and protein in colorectal cancer patients and colon cancer cell lines. J Transl Med. 2012;10:109.

310. Jiang T, Zhu A, Zhu Y, Piao D. Clinical implications of AEG-1 in liver metastasis of colorectal cancer. Med Oncol. 2012;29(4):2858-63.

311. Wang N, Du X, Zang L, Song N, Yang T, Dong R, et al. Prognostic impact of MetadherinSND1 interaction in colon cancer. Mol Biol Rep. 2012;39(12):10497-504.

312. Casimiro S, Fernandes A, Oliveira AG, Franco M, Pires R, Peres M, et al. Metadherin expression and lung relapse in patients with colorectal carcinoma. Clin Exp Metastasis. 2014;31(6):689-96.

313. Lievre A, Blons $\mathrm{H}$, Laurent-Puig P. Oncogenic mutations as predictive factors in colorectal cancer. Oncogene. 2010;29(21):3033-43.

314. Pritchard CC, Grady WM. Colorectal cancer molecular biology moves into clinical practice. Gut. 2011;60(1):116-29.

315. Majewski J, Ott J. Distribution and characterization of regulatory elements in the human genome. Genome Res. 2002;12(12):1827-36.

316. Chorev M, Carmel L. The function of introns. Front Genet. 2012;3:55.

317. Sakurai H, Suzuki S, Kawasaki N, Nakano H, Okazaki T, Chino A, et al. Tumor necrosis factor-alpha-induced IKK phosphorylation of NF-kappaB p65 on serine 536 is mediated through the TRAF2, TRAF5, and TAK1 signaling pathway. J Biol Chem. 2003;278(38):36916-23.

318. Martin AG, Trama J, Crighton D, Ryan KM, Fearnhead HO. Activation of p73 and induction of Noxa by DNA damage requires NF-kappa B. Aging (Albany NY). 2009;1(3):335-49. 
319.

Miyamoto S. Nuclear initiated NF-kappaB signaling: NEMO and ATM take center stage. Cell Res. 2011;21(1):116-30.

$320 . \quad$ Lee JH, Paull TT. ATM activation by DNA double-strand breaks through the Mre11Rad50-Nbs1 complex. Science. 2005;308(5721):551-4.

321. Li H, Chen X, Yu Y, Wang Z, Zuo Y, Li S, et al. Metformin inhibits the growth of nasopharyngeal carcinoma cells and sensitizes the cells to radiation via inhibition of the DNA damage repair pathway. Oncol Rep. 2014;32(6):2596-604.

322. Rossow L, Eke I, Dickreuter E, Cordes N. Targeting of the EGFR/beta1 integrin connecting proteins PINCH1 and Nck2 radiosensitizes three-dimensional SCC cell cultures. Oncol Rep. 2015;34(1):469-76.

323. Gatei M, Jakob B, Chen P, Kijas AW, Becherel OJ, Gueven N, et al. ATM proteindependent phosphorylation of Rad50 protein regulates DNA repair and cell cycle control. J Biol Chem. 2011;286(36):31542-56.

324. Pfeifer D, Wallin A, Holmlund B, Sun XF. Protein expression following gammairradiation relevant to growth arrest and apoptosis in colon cancer cells. J Cancer Res Clin Oncol. 2009;135(11):1583-92.

325. Rodel F, Hoffmann J, Distel L, Herrmann M, Noisternig T, Papadopoulos T, et al. Survivin as a radioresistance factor, and prognostic and therapeutic target for radiotherapy in rectal cancer. Cancer Res. 2005;65(11):4881-7.

326. Shin JS, Foo T, Hong A, Zhang M, Lum T, Solomon MJ, et al. Telomerase expression as a predictive marker of radiotherapy response in rectal cancer. Pathology. 2012;44(3):209-15.

327. Aklilu M, Eng C. The current landscape of locally advanced rectal cancer. Nat Rev Clin Oncol. 2011;8(11):649-59.

328. Gilbert A, Ziegler L, Martland M, Davidson S, Efficace F, Sebag-Montefiore D, et al. Systematic Review of Radiation Therapy Toxicity Reporting in Randomized Controlled Trials of Rectal Cancer: A Comparison of Patient-Reported Outcomes and Clinician Toxicity Reporting. Int J Radiat Oncol Biol Phys. 2015;92(3):555-67.

329. Carethers JM. Systemic treatment of advanced colorectal cancer: tailoring therapy to the tumor. Therap Adv Gastroenterol. 2008;1(1):33-42.

330. Ohe Y. Treatment-related death from chemotherapy and thoracic radiotherapy for advanced cancer. Panminerva Med. 2002;44(3):205-12.

331. Merlo LM, Pepper JW, Reid BJ, Maley CC. Cancer as an evolutionary and ecological process. Nat Rev Cancer. 2006;6(12):924-35.

332. Polyak K. Tumor heterogeneity confounds and illuminates: a case for Darwinian tumor evolution. Nat Med. 2014;20(4):344-6.

333. Aktipis CA, Boddy AM, Gatenby RA, Brown JS, Maley CC. Life history trade-offs in cancer evolution. Nat Rev Cancer. 2013;13(12):883-92.

334. Goetze K, Scholz M, Taucher-Scholz G, Mueller-Klieser W. The impact of conventional and heavy ion irradiation on tumor cell migration in vitro. Int J Radiat Biol. 2007;83(11-12):889-96.

335. Goetze K, Scholz M, Taucher-Scholz G, Mueller-Klieser W. Tumor cell migration is not influenced by $\mathrm{p} 21$ in colon carcinoma cell lines after irradiation with X-ray or (12)C heavy ions. Radiat Environ Biophys. 2010;49(3):427-35.

336. Speake WJ, Dean RA, Kumar A, Morris TM, Scholefield JH, Watson SA. Radiation induced MMP expression from rectal cancer is short lived but contributes to in vitro invasion. Eur J Surg Oncol. 2005;31(8):869-74.

337. Song H, Tian Z, Qin Y, Yao G, Fu S, Geng J. Astrocyte elevated gene-1 activates MMP9 to increase invasiveness of colorectal cancer. Tumour Biol. 2014;35(7):6679-85.

338. Liu L, Wu J, Ying Z, Chen B, Han A, Liang Y, et al. Astrocyte elevated gene-1 upregulates matrix metalloproteinase- 9 and induces human glioma invasion. Cancer Res. 2010;70(9):3750-9. 


\section{Papers}

The articles associated with this thesis have been removed for copyright reasons. For more details about these see:

http://urn.kb.se/resolve?urn=urn:nbn:se:liu:diva-121868 